Prepared for the U.S. Department of Energy

\title{
WOSMIP II - Workshop on Signatures of Medical and Industrial Isotope Production
}
M. Matthews
B. Deconninck
C. Papastefanou
P. Achim L-E. DeGeer
G. Piefer
M. Auer
M. Druce
E. Quintana
R. Bell
J. Friese
O. Ross
S. Bielgalski
R. Hague
M. Rotty
T. Bowyer
I. Hoffman
M. Sabzian
D. Braekers
E. Hoffmann
P. Saey
E. Bradley
K. Khrustalev
A. Sameh
B. Briyatmoko
J. Lucas
M. Safari
$\mathrm{H}$. Berglund
G. Mattassi
M. Schoppner
J. Camps
A. Mattila
P. Siebert
E. Carranza
H. Miley
K. Unger
F. Carty
E. Nava
A. Vargas
R. DeCaire
M. Nikkinen

\section{November 2011}

Pacific Northwest

NATIONAL LABORATORY

Proudly Operated by Battelle Since 1965 


\title{
DISCLAIMER
}

This report was prepared as an account of work sponsored by an agency of the United States Government. Neither the United States Government nor any agency thereof, nor Battelle Memorial Institute, nor any of their employees, makes any warranty, express or implied, or assumes any legal liability or responsibility for the accuracy, completeness, or usefulness of any information, apparatus, product, or process disclosed, or represents that its use would not infringe privately owned rights. Reference herein to any specific commercial product, process, or service by trade name, trademark, manufacturer, or otherwise does not necessarily constitute or imply its endorsement, recommendation, or favoring by the United States Government or any agency thereof, or Battelle Memorial Institute. The views and opinions of authors expressed herein do not necessarily state or reflect those of the United States Government or any agency thereof.

\author{
PACIFIC NORTHWEST NATIONAL LABORATORY \\ operated by \\ BATTELLE \\ for the \\ UNITED STATES DEPARTMENT OF ENERGY \\ under Contract DE-AC05-76RL01830
}

Printed in the United States of America

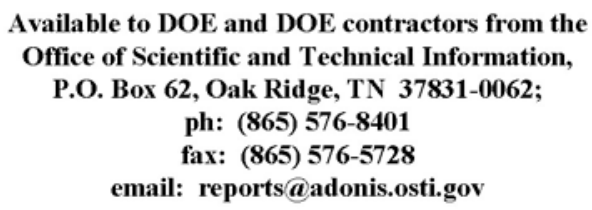

Available to the public from the National Technical Information Service 5301 Shawnee Rd., Alexandria, VA 22312 ph: (800) 553-NTIS (6847) email: orders@ntis.gov $<$ http://www.ntis.gov/about/form.aspx > Online ordering: http://www.ntis.gov 


\section{WOSMIP II - Workshop on}

\section{Signatures of Medical and}

\section{Industrial Isotope Production}

$\begin{array}{lll}\text { M. Matthews } & \text { B. Deconninck } & \text { C. Papastefanou } \\ \text { P. Achim } & \text { L-E. DeGeer } & \text { G. Piefer } \\ \text { M. Auer } & \text { M. Druce } & \text { E. Quintana } \\ \text { R. Bell } & \text { J. Friese } & \text { O. Ross } \\ \text { S. Bielgalski } & \text { R. Hague } & \text { M. Rotty } \\ \text { T. Bowyer } & \text { I. Hoffman } & \text { M. Sabzian } \\ \text { D. Braekers } & \text { E. Hoffmann } & \text { P. Saey } \\ \text { E. Bradley } & \text { K. Khrustalev } & \text { A. Sameh } \\ \text { B. Briyatmoko } & \text { J. Lucas } & \text { M. Safari } \\ \text { H. Berglund } & \text { G. Mattassi } & \text { M. Schoppner } \\ \text { J. Camps } & \text { A. Mattila } & \text { P. Siebert } \\ \text { E. Carranza } & \text { H. Miley } & \text { K. Unger } \\ \text { F. Carty } & \text { E. Nava } & \text { A. Vargas } \\ \text { R. DeCaire } & \text { M. Nikkinen } & \end{array}$

November 2011

Prepared for the U.S. Department of Energy under Contract DE-AC05-76RL01830

Pacific Northwest National Laboratory

Richland, Washington 99352 



\section{Acknowledgments}

The authors wish to extend their gratitude to Murray Matthews who compiled all the WOSMIP II session summaries to form the backbone of this paper. Dr. Matthews took notes, distilled the figures and tables from all of the presentation materials, and summarized each presentation. Without his work this paper would not have been possible.

Many thanks also to the WOSMIP session chairs, whose summaries of the sessions have been essential to this effort. These are Ted Bowyer (PNNL), Judah Friese (PNNL), Paul Saey (IAEA), Matthias Auer (CTBTO), A.A. Sameh (consultant), and Harry Miley (PNNL).

The authors and attendees greatly appreciate the efforts of Ted Bowyer and Paul Saey in hosting and coordinating the WOSMIP conference, with invaluable assistance from Jean Simpson, Laura Wilhelm and Gabriella di Strassoldo Williams.

Finally, thanks to Rosara Payne of PNNL, who acted as editor-in-chief, coordinating the preparation of the documents related to WOSMIP for publication and distribution. 

Acronyms and Abbreviations

\begin{tabular}{|c|c|}
\hline AEOI & Atomic Energy Organization of Iran \\
\hline AFTAC & Air Force Technical Applications Center \\
\hline ANSTO & Australian Nuclear Science and Technology Organisation \\
\hline ARN - Argentina & $\begin{array}{l}\text { Autoridad Regulatoria Nuclear (Nuclear Regulatory Authority - Argentina) } \\
\text { Associazione Eicherche Psicologia Analitica (Environmental Protection Regional }\end{array}$ \\
\hline ARPA & Agency) \\
\hline ATM & Atmospheric Transport Model \\
\hline BATAN & National Nuclear Energy Agency of Indonesia \\
\hline ВIOT & British Indian Ocean Territories \\
\hline CAE & Ezeiza Atomic Centre \\
\hline CNEA & CAE National Atomic Energy Commission \\
\hline CRP & Coordniated Research Project \\
\hline СТВТ & Comprehensive Nuclear-Test-Ban Treaty \\
\hline СТВТО & Comprehensive Nuclear-Test-Ban Treaty Organization \\
\hline DOE & $\begin{array}{l}\text { Department of Energy } \\
\text { Italian National Agency for New Technologies, Energy and Sustainable Economic }\end{array}$ \\
\hline ENEA & Development \\
\hline FOI & Swedish Defence Research Agency \\
\hline HEPA filter & High-efficiency particulate air filter \\
\hline HEU & Highly enriched uranium \\
\hline HFR & High flux reactor \\
\hline IAEA & International Atomic Energy Agency \\
\hline IDC & International Data Center \\
\hline IMS & International Monitoring Stations \\
\hline INL & Idaho National Laboratory \\
\hline IPF & Isoptope Production Facility \\
\hline IRE & Institute for Radioelements \\
\hline IRE-ELit & Institute for Radioelements - Environment \& Life Science Technology \\
\hline KIT & Karlsruhe Institute of Technology \\
\hline LEU & Low-enriched uranium \\
\hline \multicolumn{2}{|l|}{ NAEA - } \\
\hline Indonesia & National Atomic Energy Agency - Indonesia \\
\hline NDC & National Data Center \\
\hline NDC Germany & National Data Center Germany \\
\hline NNSA & National Nuclear Security Administration \\
\hline NPP & Nuclear Power Plant \\
\hline OPAL facility & ANSTO's Open Pool Australian Lightwater facility \\
\hline ORIGEN & Oak Ridge Isotope GENeration code \\
\hline PNNL & Pacific Northwest National Laboratory \\
\hline PTBN & Center for Nuclear Fuel Technology - Indonesia \\
\hline
\end{tabular}




$\begin{array}{ll}\text { RASA } & \text { Radionuclide Aerosol Sampler/Analyzer } \\ \text { SAUNA } & \begin{array}{l}\text { Swedish Automatic Unit for Noble Gas Acquisition } \\ \text { Studiecentrum Voor Kernenergie*Centre D'Etude de L'Energie Nucleaire (Belgian }\end{array} \\ \text { SCK-CEN } & \text { Nuclear Research Center) } \\ \text { STUK } & \text { Radiation and Nuclear Safety Authority Finland } \\ \text { TRR } & \text { Tehran Research Reactor } \\ \text { UK } & \text { United Kingdom } \\ \text { USA } & \text { United States of America } \\ \text { WOSMIP } & \text { Workshop on the Signatures of Medical and Industrial Isotope Production }\end{array}$




\section{Contents}

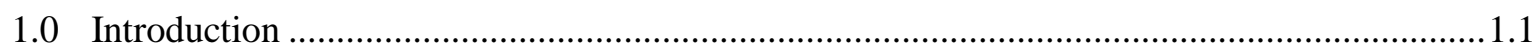

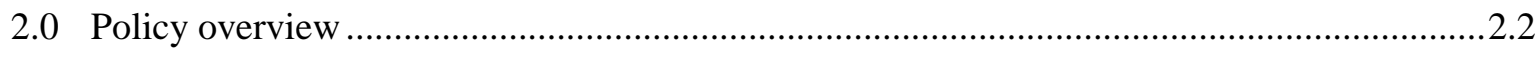

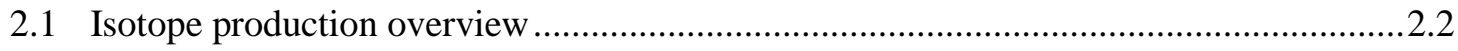

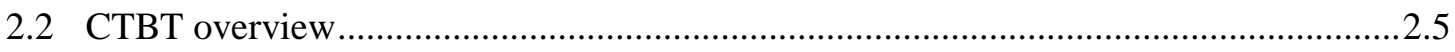

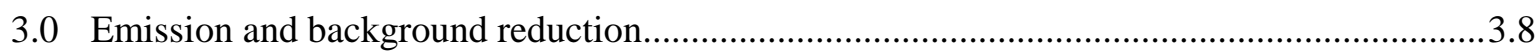

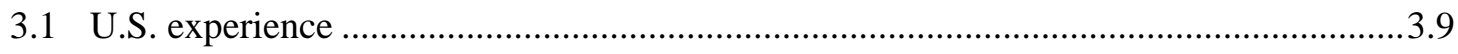

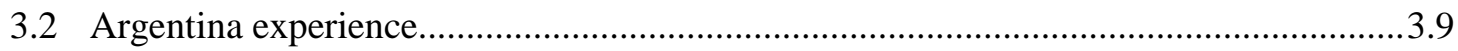

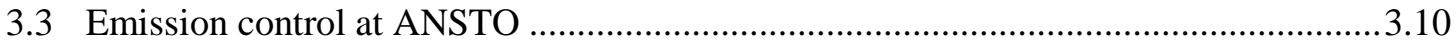

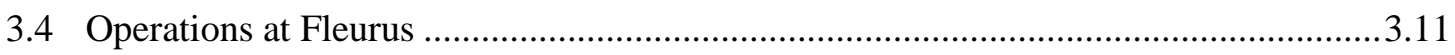

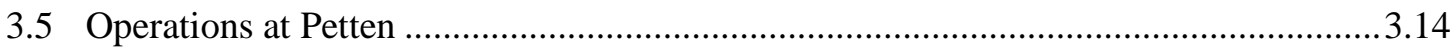

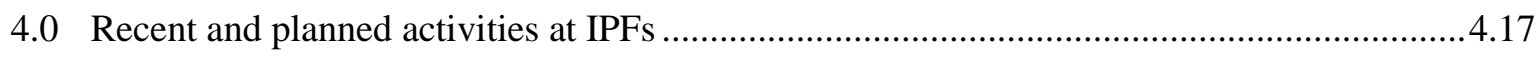

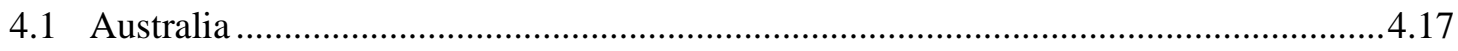

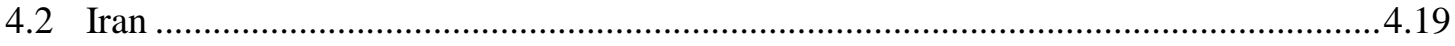

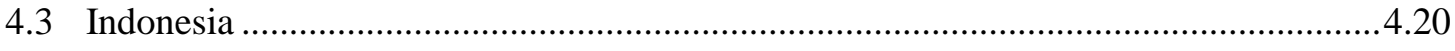

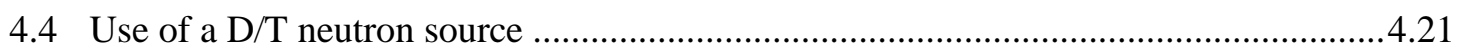

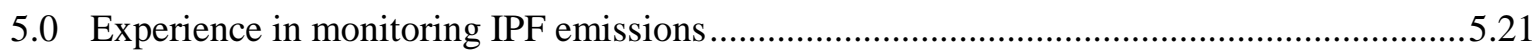

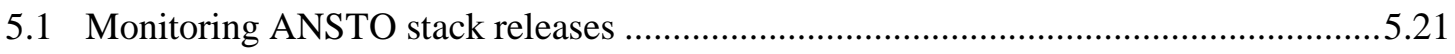

5.2 Release monitoring and mitigation at the Nordion plant.............................................25

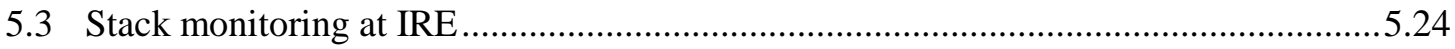

5.4 Characterization of radio-xenon discharges in Belgium ..............................................5.26

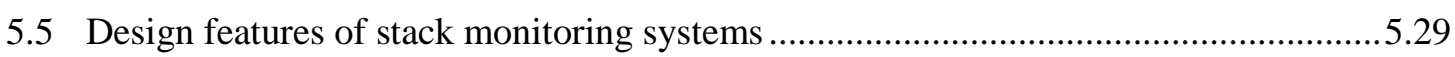

5.6 Effects of IPFs on CTBT xenon-monitoring stations ..................................................29

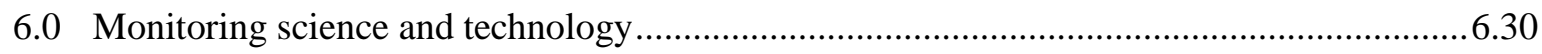

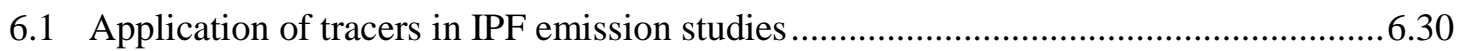

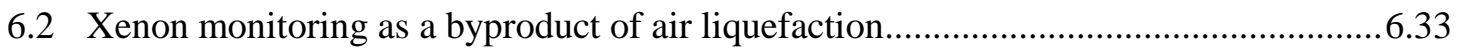

6.3 SAUNA - equipment for low-level measurement of radioxenon ................................6.34

6.4 Equipment under development for xenon measurements in Italy .................................6.35

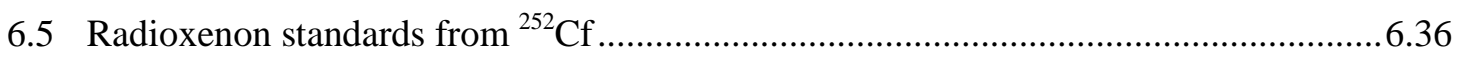

6.6 The role of ATM in distinguishing civilian and military xenon sources ....................6.37

6.7 Optimization of the CTBT noble-gas network...............................................................

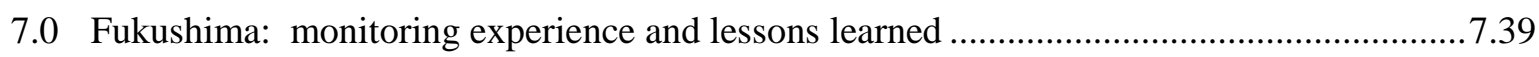

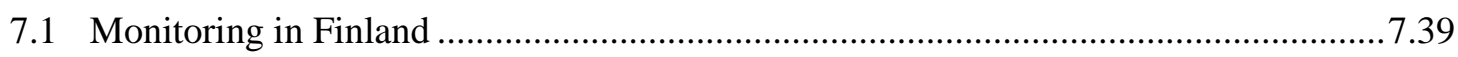


7.2 Fukushima fallout monitoring in Greece................................................................... 7.41

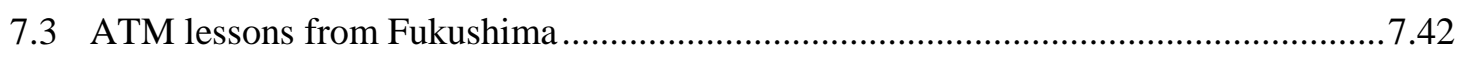

7.4 CTBT-related Fukushima experience and lessons learned ...........................................4.

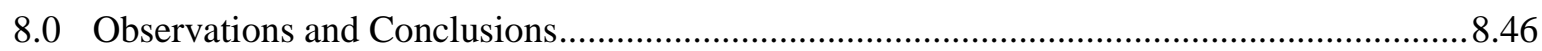

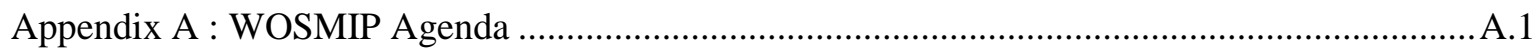




\section{Figures}

Figure 2.1. ${ }^{99}$ Mo production volume (in Curies) required to meet delivery targets.......................2.3

Figure 2.2. Current major global producers and suppliers of ${ }^{99}$ Mo. ...............................................

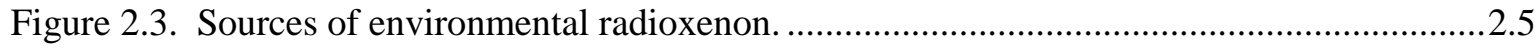

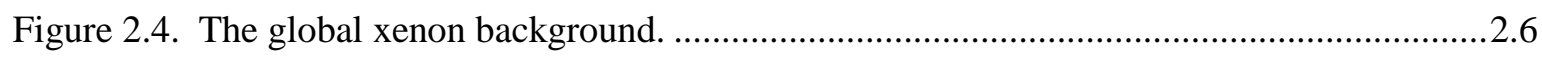

Figure 2.5. Distinction of radioxenon sources based on isotopic ratios.......................................2.8

Figure 3.1. Nuclear facilities in Argentina.................................................................................10

Figure 3.2. Annual total noble-gas emissions from the ANSTO facility (the regulatory limit is shown by the red line). The new LEU process was introduced in 2008/9..............................11

Figure 3.3. The principle of adsorption-bed control of xenon emissions. .....................................12

Figure 3.4. Flow diagram of the Fleurus xenon-emission control system.....................................13

Figure 3.5. A schematic diagram of the Petten ${ }^{99}$ Mo production process......................................15

Figure 3.6. Dissolver off-gas handling at Petten......................................................................15

Figure 3.7. Cell and equipment ventilation at Petten.................................................................16

Figure 3.8. Overall ${ }^{99}$ Mo production cycle at Petten..................................................................17

Figure 3.9. Xenon enrichment of the dissolver off-gas................................................................17

Figure 4.1. The ANSTO ${ }^{99}$ Mo production process. .................................................................4.18

Figure 4.2. Configurable carbon filters deployed at ANSTO.................................................4.19

Figure 4.3. Fabrication of LEU targets in Indonesia...............................................................20

Figure 5.1. Low-resolution ANSTO stack monitor, with detector viewing a $100 \mathrm{~mL}$ chamber...5.22

Figure 5.2. ANSTO prototype high-resolution stack monitor. ................................................5.22

Figure 5.3. The ventilation monitoring system at the Nordion plant...........................................5.23

Figure 5.4. Xenon trapping system employed at the Nordion plant. ...........................................5.24

Figure 5.5. Schematic description of IRE production process.................................................5.25

Figure 5.6. High-resolution monitoring system developed for IRE main stack. .........................5.26

Figure 5.7. Xenon isotope releases from sources identified in Belgium......................................5.27

Figure 5.8. Average air concentration of ${ }^{133} \mathrm{Xe}$ around Belgian facilities...................................5.28

Figure 6.1. Radioxenon isotope-ratio signatures of a ${ }^{235} \mathrm{U}$ weapon detonation............................6.31

Figure 6.2. Radioxenon signatures overlap between radiopharmaceutical production and a uranium-based nuclear-weapon explosion.

Figure 6.3. The effect on the isotope-ratio signature when natural Xe is irradiated with the $\mathrm{U}$

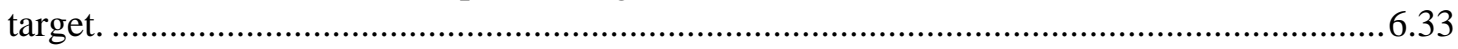

Figure 6.4. The SAUNA II system deployed at IMS noble-gas stations. ..................................6.35

Figure 6.5. Elements of the ENEA xenon monitoring measurement system..............................6.36

Figure 6.6. Present IMS noble-gas network performance......................................................6.38

Figure 6.7. Proposed optimized 57-station IMS network. ...................................................6.39

Figure 7.1. Particulate (blue), gaseous (red) and total (green) ${ }^{131}$ I concentrations in Helsinki (HEL). The gaseous fraction was between $80 \%$ - 95\% in most samples collected in Helsinki

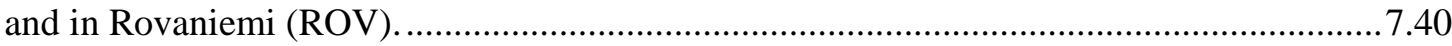


Figure 7.2. Particulate ${ }^{131} \mathrm{I} /{ }^{137} \mathrm{Cs}$ ratios at samples collected at different monitoring stations over a two month period.

Figure 7.3. Comparison of particulate and xenon trends in detections from Fukushima..............7.43

Figure 7.4. Lessons learned at the IDC

.7 .44

Figure 7.5. ${ }^{137} \mathrm{Cs}$ and ${ }^{136} \mathrm{Cs}$ data compared across the IMS network. 


\section{Tables}

Table 2.1. Characteristics and applications of the principal radioxenon isotopes. ........................2.7

Table 5.1. Summary of annual released activities (Bq) of radio-xenon isotopes in Belgium.......5.27

Table 5.2. The IPF-effect flagging system for IMS stations....................................................5.29

Table 5.3. Degrees of influence by IPFs at IMS noble-gas stations. ........................................5.30 



\subsection{Introduction}

Medical and industrial radioisotopes are fundamental tools used in science, medicine and industry with an ever expanding usage in medical practice where their availability is vital. Very sensitive environmental radionuclide monitoring networks have been developed for nuclear-security-related monitoring [particularly Comprehensive Test-Ban-Treaty (CTBT) compliance verification] and are now operational. The possibility that emissions from the all-important production facilities might impinge adversely on these monitoring operations was first raised in 2002. In the following years, as an increasing volume of monitoring data from around the world became available, specific measurement campaigns took place and all doubt over this possibility was removed and the seriousness of the issue realized. The recent Fukushima nuclear event overshadowed the issue somewhat by introducing another set of source-term variables.

WOSMIP I, held in July 2009, was an experiment to bring scientists from different communities together to discuss issues surrounding the release of effluents from medical and industrial isotope production facilities, particularly the impact these releases potentially have on environmental monitoring operations concerned with detection of noble gases released from nuclear activities. As reported in the WOSMIP I report, that meeting was very successful in raising awareness within the "producing” and "monitoring” communities of the technical issues and concerns facing the two groups. The meeting also raised awareness of radiopharmaceutical production and noble gas monitoring generally, as indicated by the number of Google "hits" on these topics which suddenly increased by a factor of five immediately after WOSMIP I and has continued to increase since.

WOSMIP II continued the experiment, with the two groups again represented by individuals from many countries and organizations. The aim was to build on the foundation laid at the previous meeting - to move onward with increasingly technical presentations and discussions, with a focus on emission reductions which might be achievable. Research and development carried out since WOSMIP I in the areas of emission reduction, production techniques and environmental monitoring was to be highlighted, together with the impact of the Fukushima nuclear event on monitoring philosophy. While WOSMIP I succeeded in raising attention to impacts of civilian emissions on security-related monitoring, further work was envisaged for WOSMIP II, particularly concerning how awareness might continue to be raised across the whole spectrum of involvement, from industry to politics, and to identify areas where further research and development are needed. 
With the goal of better understanding the isotopic and chemical signatures created through isotope production mechanisms, the Workshop program was divided into six areas in which oral presentations were supported by a poster session.

1. Policy overview

2. Emission and background reduction

3. Recent and planned activities at production facilities

4. Experience in monitoring medical isotope production facilities

5. Monitoring science and technology

6. Fukushima: monitoring experience and lessons learned

Two awards were also made for Outstanding Demonstration of Effluent Reduction Techniques and Outstanding Scientific Investigation of Isotopic Signatures.

\subsection{Policy overview}

Overviews of medical isotope production, its relevance to policy makers, and the Comprehensive Nuclear-Test-Ban Treaty verification regime were given respectively by Ed Bradley (IAEA), Randy Bell (DOE/NNSA, USA) and Matthias Auer (CTBTO).

\subsection{Isotope production overview}

To be useful, medical isotopes must satisfy three criteria: (1) appropriate half-life - long enough to allow supply and short enough to minimize any negative health impact; (2) decay energy suitable for the application; and (3) ease of production. Their main use is in diagnosis and treatment. ${ }^{99 \mathrm{~m}} \mathrm{Tc}$ is the most widely used isotope, particularly in examining functions of the heart, liver or thyroid; in blood flow studies; and together with therapeutic use in treatment of prostate, breast and bone tumors. Overall, some 30 million procedures are conducted annually.

For the ${ }^{99 \mathrm{~m}} \mathrm{Tc}$ parent, ${ }^{99} \mathrm{Mo}$, the amount produced has to be much larger than that required in order to satisfy the current global demand of approximately 12,000 “six-day-curies” as shown in Figure 2.1. 


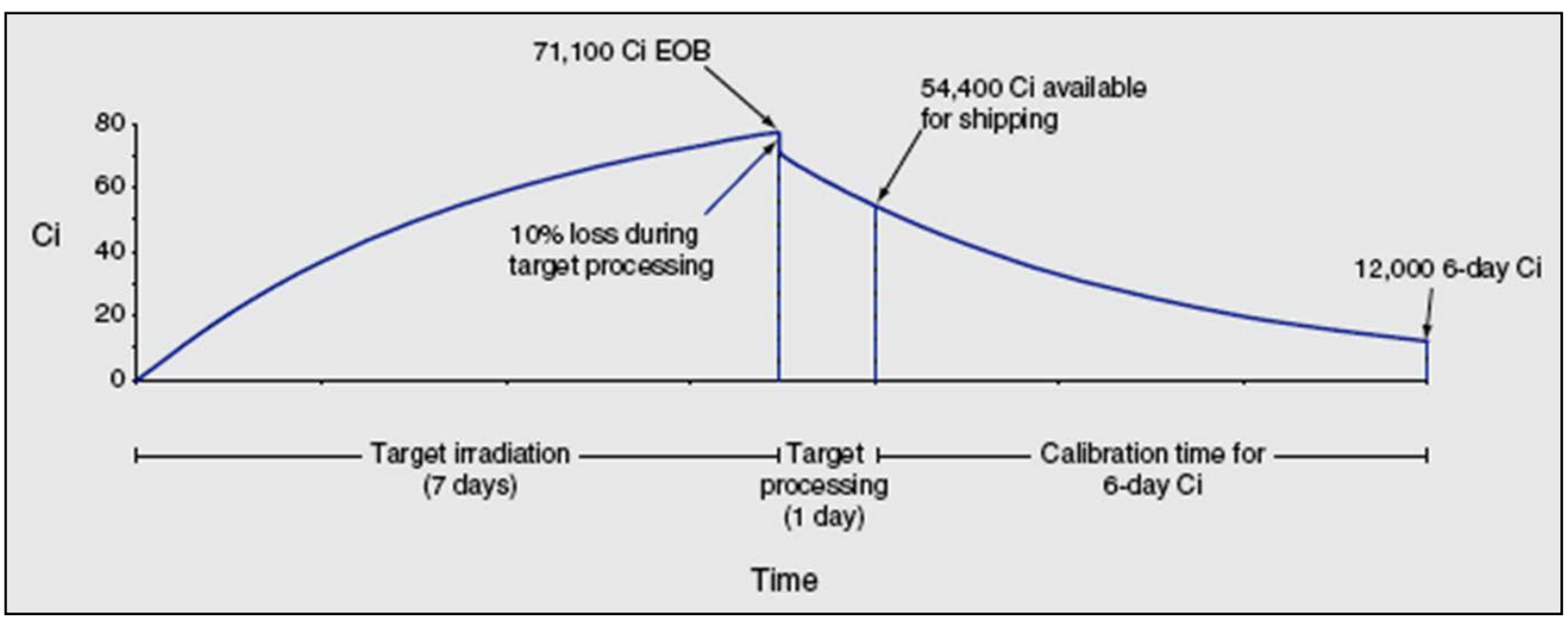

Figure 2.1. ${ }^{99}$ Mo production volume (in Curies) required to meet delivery targets.

A number of problems currently face the supply chain, with conditions existing for a supply crisis: most production reactors are aging (more than half are over 40 years old, with recurrent technical problems); the market is dysfunctional, having developed with reliance on government-constructed and -funded research reactors rather than with more economically sustainable full cost recovery; there are flawed international policies including binding contracts with ${ }^{99}$ Mo suppliers; and there is increasing demand in times of recurrent shortages (caused, for example, by the 2010 Iceland volcano eruption as well as reactor and production facility shutdowns). The United States is the world's largest market ( 50\%) but has no domestic production facilities, although some awards and cooperation agreements have been made with various commercial bodies. Similar awards have been made by the Canadian government in an apparent effort to secure national ${ }^{99} \mathrm{Mo} /{ }^{99 \mathrm{~m}} \mathrm{Tc}$ supply. With problems arising from aging facilities in Canada, Netherlands, Belgium, France and South Africa, increased production and new suppliers may appear in Australia, Canada, China, Korea and Brazil. The IAEA is supporting the development of new facilities with a focus on ensuring ${ }^{99}$ Mo supply security for all Member States while encouraging the transition away from HEU. Current major ${ }^{99}$ Mo suppliers are depicted in Figure 2.2. 

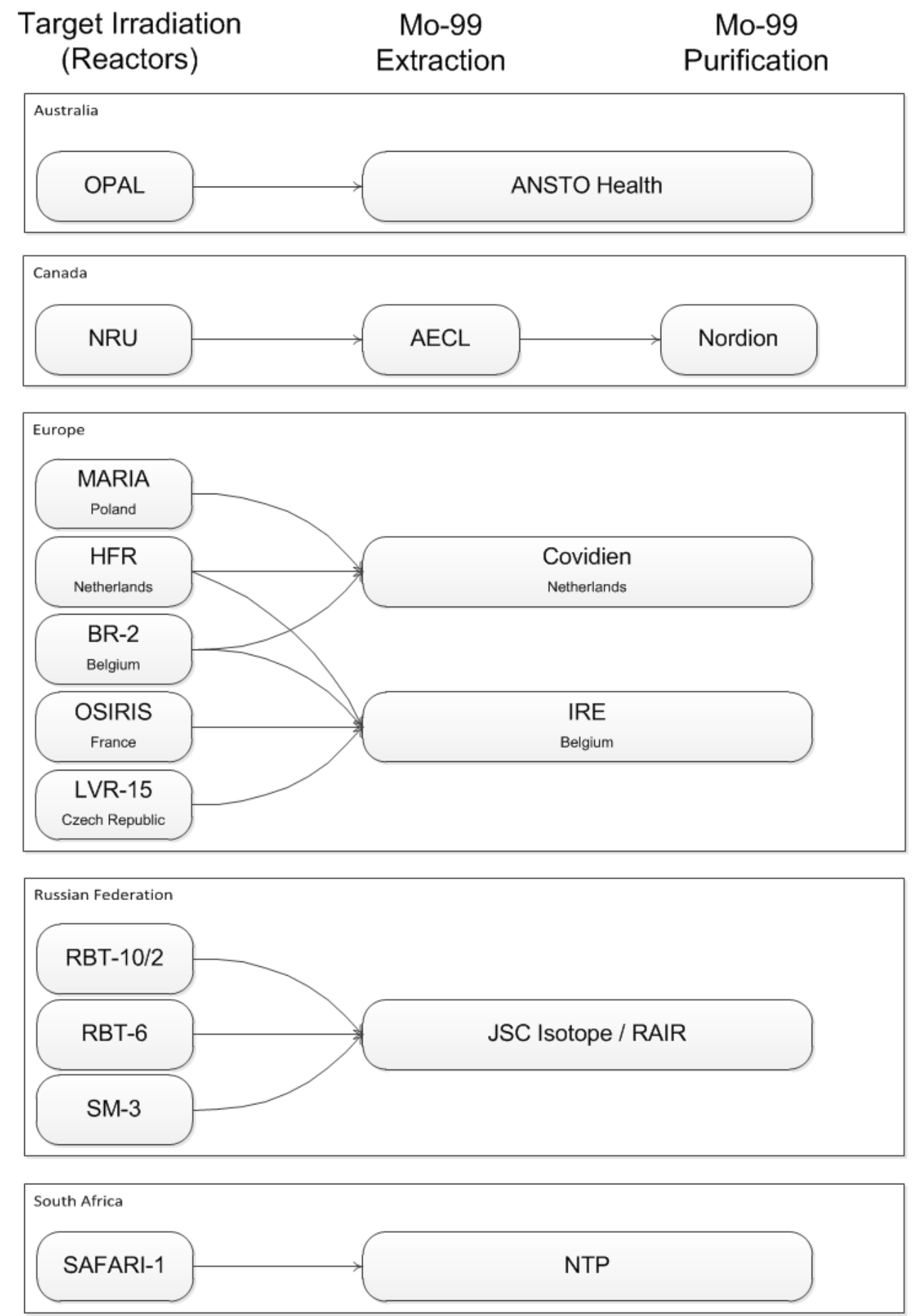

Figure 2.2. Current major global producers and suppliers of ${ }^{99}$ Mo.

Unambiguous identification of an explosion as being of a nuclear nature is only possible with detection of the resulting radionuclides, both particulate and noble gas. However, isotope production facilities (IPFs) 
create a background which confuses the picture. An analogy may be drawn with the seismic "explosion background” being complicated by chemical explosions which occur all the time around the globe.

The supply of medical isotopes is critical and there is a growing international consensus on the need for it and recognition of the associated non-proliferation issues is emerging. So while xenon isotopes are important in nuclear weapon test monitoring, the situation is complicated by releases from IPFs. Positive features of isotope production include the move away from highly enriched uranium (HEU) and the increasing focus by IPFs on reducing emissions - a key point for discussion in the WOSMIP meetings.

\subsection{CTBT overview}

Sources of radioxenon isotopes prevalent in the environment are summarized in Figure 2.3.

\begin{tabular}{|c|c|}
\hline Source & Emissions \\
\hline $\begin{array}{l}1 \mathrm{kT} \text { nuclear } \\
\text { explosion }\end{array}$ & $\begin{array}{l}\text { Atmospheric test: } 10^{16} \mathrm{~Bq} \\
\text { Underground test: } \sim 10^{14} \mathrm{~Bq}\left(0-10^{15} \mathrm{~Bq}\right) \\
\text { mainly }{ }^{133} \mathrm{Xe},{ }^{133 \mathrm{~m}} \mathrm{Xe} \text { and }{ }^{135} \mathrm{Xe}\end{array}$ \\
\hline $\begin{array}{l}\text { Nuclear } \\
\text { reactors }\end{array}$ & $\begin{array}{l}\text { Release: } 10^{9} \mathrm{~Bq} / \mathrm{d} \\
\text { Global: } 10^{15} \mathrm{~Bq} / \mathrm{a} \\
\text { Regional impact / mainly }{ }^{133} \mathrm{Xe}\end{array}$ \\
\hline Hospitals & $\begin{array}{l}10^{6} \mathrm{~Bq} \\
\text { Local impact / } 131 \mathrm{~m} \mathrm{Xe}\end{array}$ \\
\hline $\begin{array}{l}99 \mathrm{~m} T \mathrm{Tc} \\
\text { production }\end{array}$ & $\begin{array}{l}\text { Per facility } 10^{13} \mathrm{~Bq} / \mathrm{d} \\
\text { Global: } 10^{16} \mathrm{~Bq} / \mathrm{a} \\
\text { Long range impact / all isotopes }\end{array}$ \\
\hline
\end{tabular}

Figure 2.3. Sources of environmental radioxenon. 
Together, these sources provide a global “xenon background” as depicted in Figure 2.4.

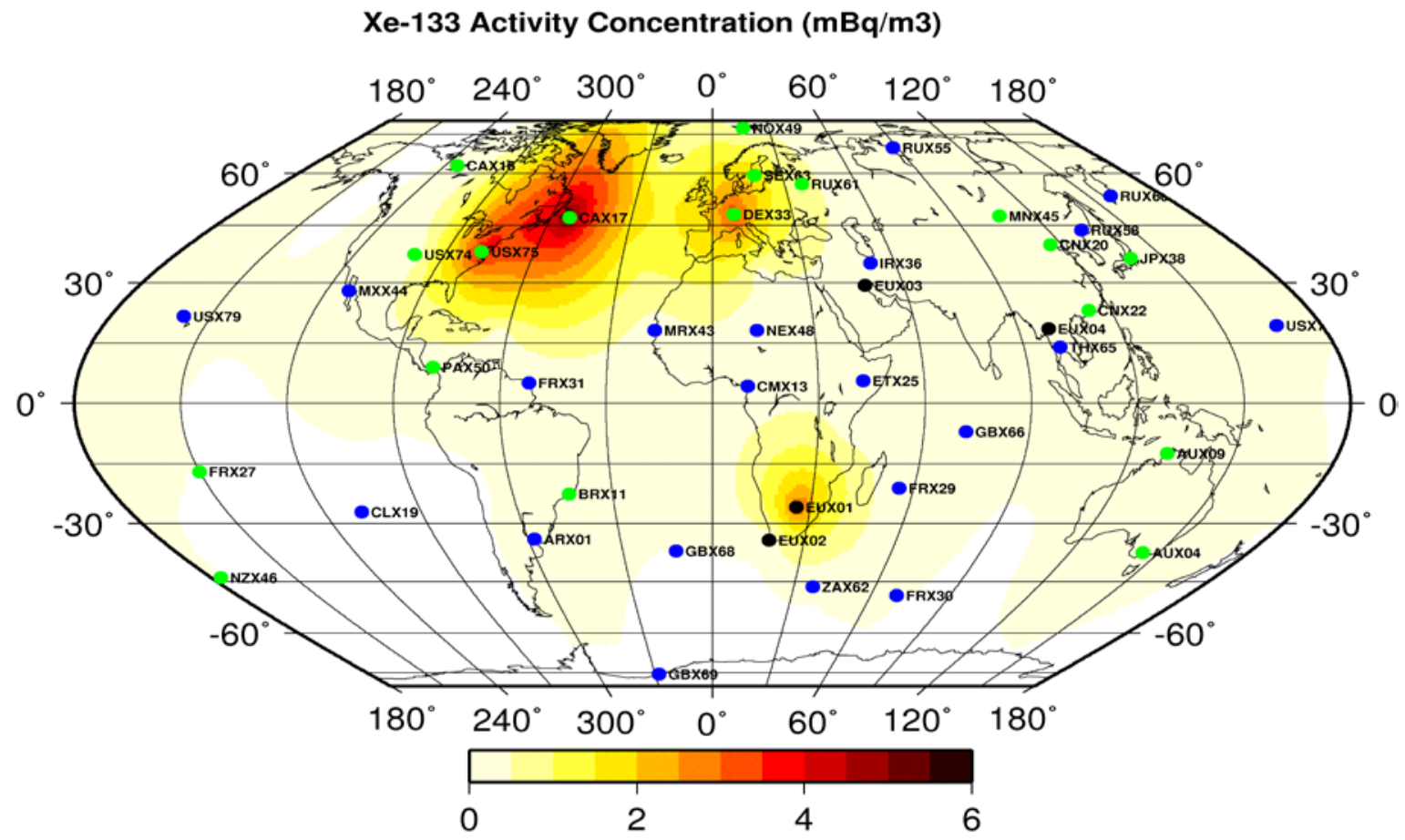

Figure 2.4. The global xenon background.

Against this background, Article 1 of the CTBT states: "Each State Party undertakes not to carry out any nuclear weapon test explosion or any other nuclear explosion”.

The purpose of the International Monitoring System (IMS) is Treaty verification. Should a suspicious event occur, verification requires that the IMS provides data which assists with the determination of whether or not a weapon test has occurred. Although all monitoring techniques (seismic, hydroacoustic, infrasound, and radionuclide) contribute to this process, comprehensive verification is only possible with conclusive radionuclide detection and an atmospheric transport model (ATM) plume definition from the detection back to the source that may have been initially identified through other detection techniques. The IMS comprises a worldwide distribution of radionuclide monitoring stations including 80 particulate systems and provisionally 40 noble gas systems. The station distribution under the Treaty is spread across the globe in order to provide a high probability of detection. High probability of detection requires that all stations provide continuous data. If any stations are removed from the network for any reason, the network's ability to provide detection is eroded, potentially leaving 'holes' or gaps in the 
network. The proliferation of IPFs and the resulting effluent releases has the potential to 'blind' critical elements of the IMS by increasing the background levels of key isotopes and masking clandestine nuclear activities thus reducing the radionuclide network's ability to provide conclusive detection and verification that a nuclear test has occurred.

Among the four verification technologies of the CTBT, the strength of radionuclide monitoring is the ability to provide evidence of a nuclear explosion by measurement of fission and/or activation products.

Characteristics and applications of the principal radioxenon isotopes are summarized in Table 2.1. Their importance is based on the following factors:

1. It has the highest fission yield of all the noble gases;

2. It has isotope half-lives of $9.1 \mathrm{~h}$ to $11.9 \mathrm{~d}$ which are convenient for analysis;

3. The half-lives are short enough not to cause atmospheric "memory" effects; and

4. It has unique properties which allow escape from underground chambers.

\begin{tabular}{|c|c|c|}
\hline Isotope & Indicative of: & Characteristics \\
\hline $\begin{array}{l}{ }^{135} \mathrm{Xe} \\
\mathrm{T}_{1 / 2}=9.1 \mathrm{~h}\end{array}$ & Nuclear explosions / medical isotope production & $\begin{array}{l}\text { Short half-life, high fission yield, } \\
\text { reactor poison }\end{array}$ \\
\hline $\begin{array}{l}{ }^{133} \mathrm{Xe} \\
\mathrm{T}_{1 / 2}=5.24 \mathrm{~d}\end{array}$ & $\begin{array}{l}\text { Nuclear explosions / medical isotope production/ } \\
\text { nuclear reactors }\end{array}$ & High fission yield \\
\hline $\begin{array}{l}{ }^{133 \mathrm{~m}} \mathrm{Xe} \\
\mathrm{T}_{1 / 2}=2.19 \mathrm{~d}\end{array}$ & Nuclear explosions / medical isotope production & $\begin{array}{l}\text { Medium half-life and fission } \\
\text { yield }\end{array}$ \\
\hline $\begin{array}{l}{ }^{131 \mathrm{~m}} \mathrm{Xe} \\
\mathrm{T}_{1 / 2}=11.9 \mathrm{~d}\end{array}$ & $\begin{array}{l}\text { Medical applications }\left({ }^{131} \mathrm{I}\right) / \text { medical isotope } \\
\text { production }\end{array}$ & Low fission yield / long half life \\
\hline
\end{tabular}

Table 2.1. Characteristics and applications of the principal radioxenon isotopes. 
The distinction between sources of Xe isotopes depends on isotopic ratios as explained in Figure 2.5. For IPF emissions, however, the distinction is not straightforward, as these emissions can have isotopic composition similar to a nuclear explosion source.

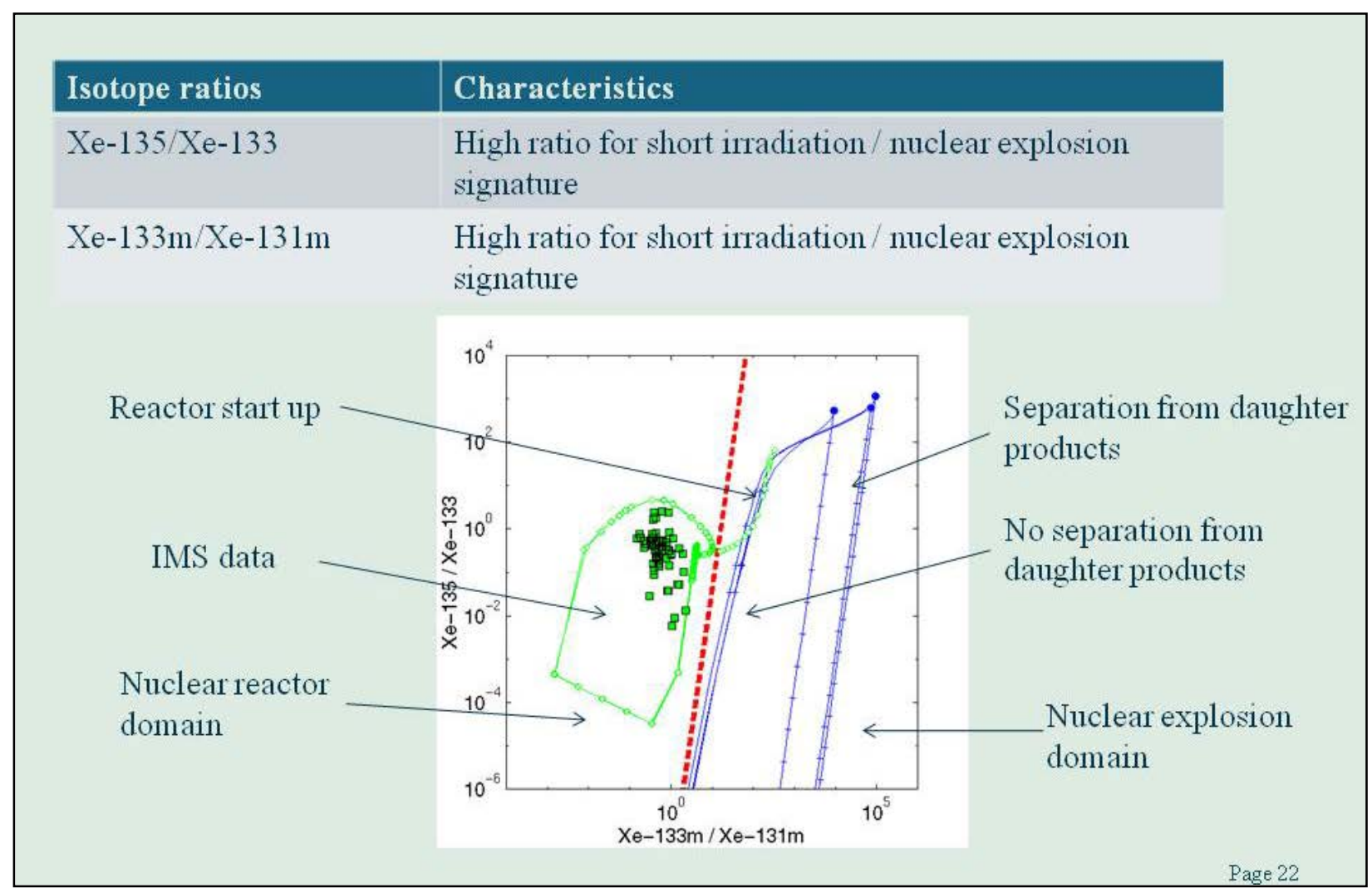

Figure 2.5. Distinction of radioxenon sources based on isotopic ratios.

Radioxenon is thus a key component of the verification effort in that it can provide the strongest evidence for underground explosions. Distinction of explosion signals from the background is obviously crucial and, as this is caused mainly by IPFs, there is a need to reduce the impact of isotope production.

\subsection{Emission and background reduction}

The reduction of emissions from IPFs and the resulting lowering of the xenon background were discussed in terms of presentations provided by A. A. Sameh (Germany), Fitz Carty (General Dynamics, USA), 
Emmy Hoffmann (ANSTO, Australia), Damien Braekers (SCK-CEN, Belgium) and Eduardo Quintana (ARN, Argentina).

\subsection{U.S. experience}

One example of the impact of IPF emissions on environmental monitoring is illustrated by the experience of General Dynamics in the United States, which serves as the station operator for all the U.S. IMS Radionuclide Stations as well as the UK station in British Indian Ocean Territories (BIOT). The most immediate concern for the U.S. IMS network performance would be medical isotope production plants planned for areas near any U.S. IMS radionuclide station, such as one possible in Lynchburg VA. A hypothetical plant at this location would be within 60 miles of the U.S. IMS Station RN75 near Charlottesville, and directly upwind. RN75 has both a Radionuclide Aerosol Sampler/Analyzer (RASA) System for particulate sampling and a Swedish Automatic Unit for Noble Gas Acquisition (SAUNA) System for noble gas sampling. The prevailing winds in this area make it likely that the any effluent releases from the plant will directly and almost immediately affect the performance of RN75. The levels of xenon isotopes expected will almost certainly exceed the dynamic range of the SAUNA system and effectively blind the station on a continuous basis leaving a gap in the verification coverage. Solutions to this problem may potentially involve use of alternative medical isotope production techniques, development of techniques to contain production plant effluent, alternative detection techniques, or combinations of these. An intermediate step may be to relocate the affected stations but the issue is, "To where?” Weather patterns and the impact of low-level low-pressure systems tend to spread effluent releases over broad regions - the entire eastern United States, for example. Even moving the station in the prevailing upwind direction would therefore provide only a limited solution because low pressure patterns affect the eastern United States every three to five days. Additionally, obtaining the CTBTO signatory approvals necessary to move a station is a significant effort and expense with a limited return.

\subsection{Argentina experience}

Another example involves monitoring experience in Argentina where ${ }^{99} \mathrm{Mo}$ is produced at the Ezeiza Atomic Centre (CAE), providing approximately 5\% of the world supply (nuclear facilities in Argentina are shown in Figure 3.1). There, production of ${ }^{99}$ Mo from fission of low-enrichment uranium (LEU) is carried out in RA3 reactor at CAE National Atomic Energy Commission (CNEA). Since 2002, ${ }^{99}$ Mo 
production has tripled. Iodine-131 is obtained as a by-product of the ${ }^{99}$ Mo production. Discharges from the plants are regulated by Nuclear Regulatory Authority (ARN). Two radiopharmaceutical companies in Buenos Aires area (BACON SAIC \& TECNONUCLEAR SA) receive bulk ${ }^{99}$ Mo (3.7 - 4.5 TBq per week) from CNEA and produce ${ }^{99}$ Mo generators. The ${ }^{99 \mathrm{~m}} \mathrm{Tc}$ is used in more than 300 nuclear medicine centres regulated by ARN. Over the last five years a significant number of detections of ${ }^{99 \mathrm{~m}} \mathrm{Tc}$ and ${ }^{131} \mathrm{I}$ have been made by the IMS station in Buenos Aires (ARP01), with 20 - 50 samples per year containing one or both of these nuclides. Potential sources are the IPFs, situated to the west or southwest of the station, and the nuclear medicine centres located in the city and close to the station. Detection events coincide mainly with winds from the south, indicating installations in that direction are the most likely sources.

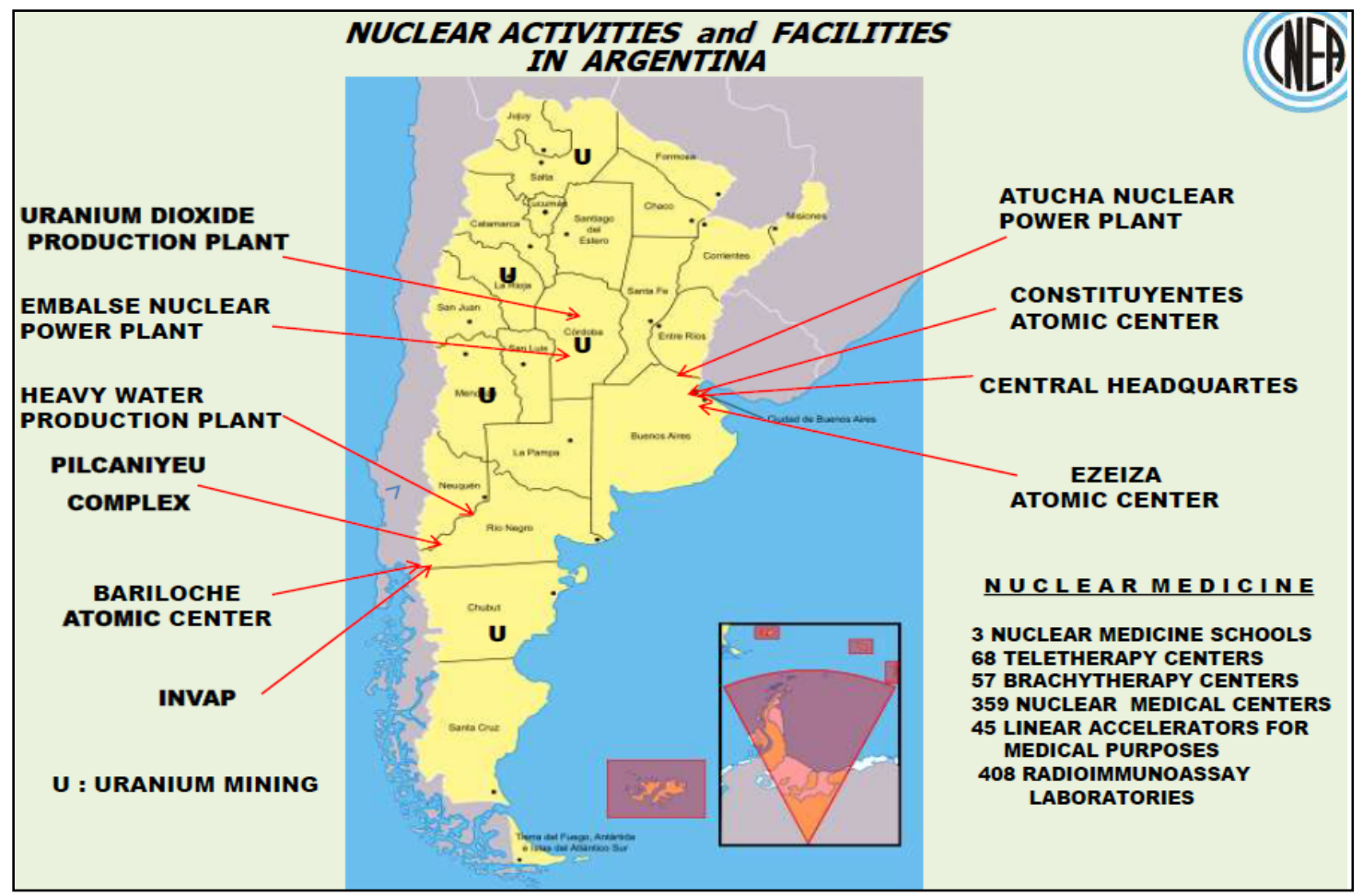

Figure 3.1. Nuclear facilities in Argentina

These examples highlight the need for attention to emission monitoring and control.

\subsection{Emission control at ANSTO}

In Australia at the ANSTO OPAL facility, increased ${ }^{99}$ Mo production has been achieved with the regulatory requirement that emissions must be kept below 1999 levels. This has required special attention 
to monitoring and mitigating releases. In-line monitoring is conducted for ${ }^{133} \mathrm{Xe},{ }^{135} \mathrm{Xe},{ }^{135 \mathrm{~m}} \mathrm{Xe},{ }^{87} \mathrm{Kr},{ }^{88} \mathrm{Kr}$ and ${ }^{85 \mathrm{~m}} \mathrm{Kr}$, with off-line monitoring for ${ }^{131} \mathrm{I},{ }^{132} \mathrm{I}$ and ${ }^{133} \mathrm{I}$. Emission reductions from the ${ }^{99}$ Mo process are achieved by the following measures: (1) a vacuum is used to transport gases and solutions, with vacuum maintained by 120-litre buffer tanks; (2) gases arising from $\mathrm{U}$ target dissolution are trapped and stored in tanks for 4 - 6 weeks to decay before release via hot cell systems; (3) hot-cell exhaust passes through high-efficiency particulate air (HEPA) \& carbon filters prior to discharge via chimney stack; (4) venting of any gases trapped in pipework, purge lines or traps is minimized. In ${ }^{131}$ I production, trapped iodine isotopes in waste streams are retained on ion exchange columns which are stored in-cell for 6 months for decay; carbon filters capture iodine from off-gases or vacuum system; and carbon filters are deployed in the extract ventilation system. Annual total noble-gas emissions are shown in Figure 3.2.

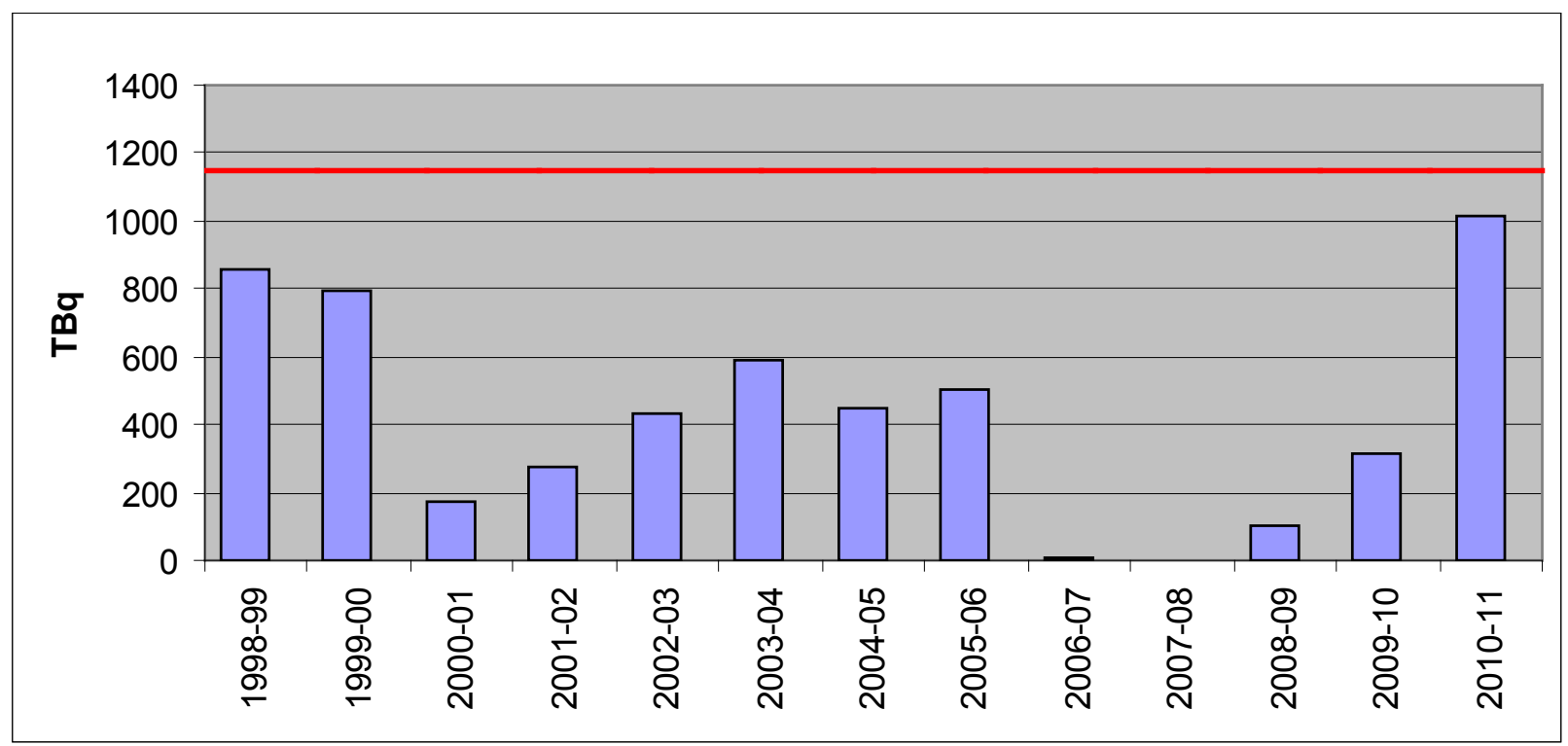

Figure 3.2. Annual total noble-gas emissions from the ANSTO facility (the regulatory limit is shown by the red line). The new LEU process was introduced in 2008/9.

\subsection{Operations at Fleurus}

The European Fleurus site is relatively large and complex. The reduction of radioxenon emissions from such large ${ }^{99}$ Mo production facilities is a key issue for the improvement of the IMS noble gases monitoring stations efficiency. The Institute for Radioelements (IRE), located in Fleurus, Belgium, is a major producer of medical isotopes from HEU targets (up to $93 \%{ }^{235} \mathrm{U}$ ). The production is not limited to ${ }^{99} \mathrm{Mo}$. Other isotopes, such as ${ }^{131} \mathrm{I}$ and ${ }^{133} \mathrm{Xe}$ which are important regarding the potential radioxenon releases, are also separated and purified. Another medical isotopes producer, Best Medical, operates its 
productions of ${ }^{131} \mathrm{I}$ and ${ }^{133} \mathrm{Xe}$ on the same site and shares with IRE the same ventilation stack. The HEU targets are not irradiated on site, but in different research reactors such as the BR2 reactor at the SCK $\cdot \mathrm{CEN}$ in Belgium, the Osiris and Orphee reactors at Saclay in France or the HFR reactor at Petten in the Netherlands. Due to the complexity of the Fleurus site, with multiple radioxenon release sources within the facility, a significant volume of contaminated gases has to be treated.

Adsorption on solid materials is a well-known technique that can be applied to treat a gaseous effluent contaminated by radioxenon, such as the off-gases released by a radiopharmaceutical ${ }^{99}$ Mo production plant. This process based on the weak interactions between xenon and the surface of a solid material inside an adsorption bed is able to retain the xenon during a sufficient time (retention time $\boldsymbol{t}_{\boldsymbol{r}}$ ) in order that the diffusion processes and the radioactive decay reduce the radioxenon activity release at the output of the bed, as shown in Figure 3.3.

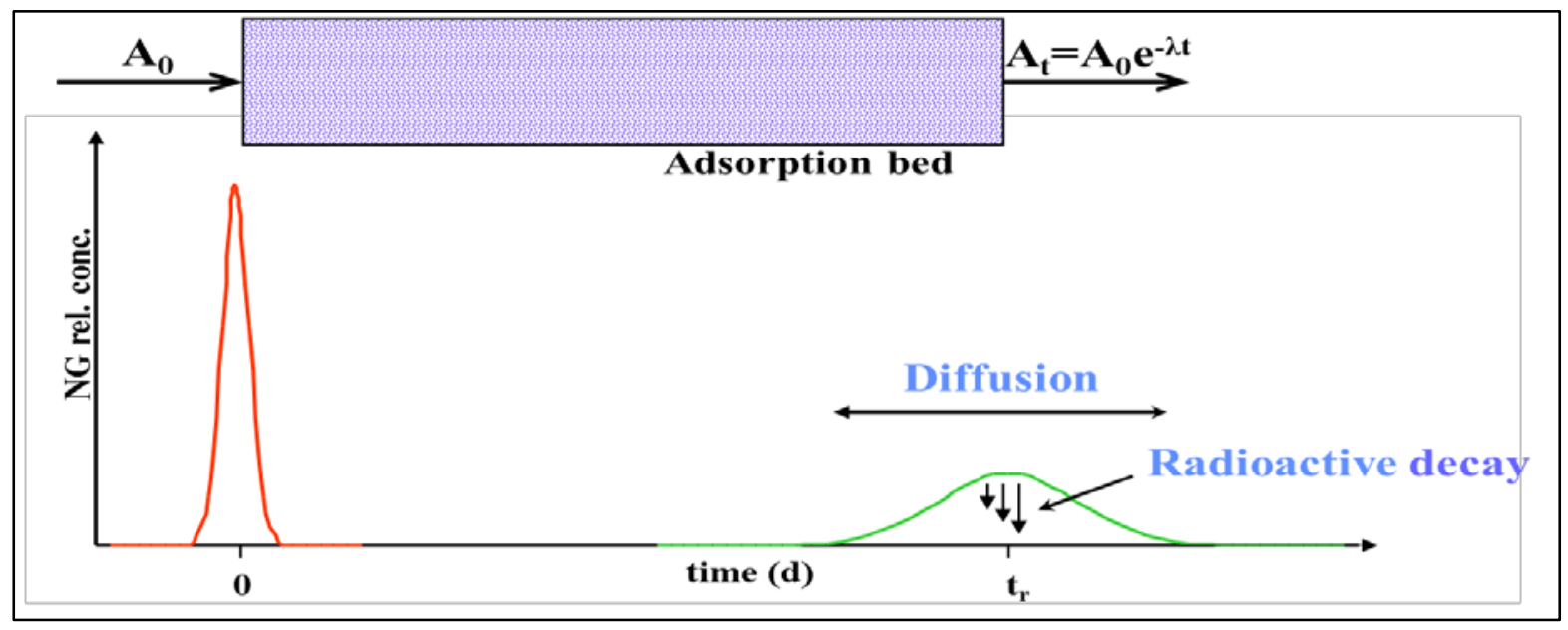

Figure 3.3. The principle of adsorption-bed control of xenon emissions.

This retention time is a key parameter for the efficiency of the radioxenon filtration system and depends mainly on the nature of the adsorbent, the size of the bed, the adsorption coefficient $\left(K_{a d s}\right)$ and the flow rate of the carrier gas. Activated carbons and silver-zeolites are two types of porous materials that have a high adsorption coefficient for xenon. The coefficient depends also on the temperature, the pressure and the composition of the carrier gas. All these parameters can be optimized in order to increase the retention time of xenon inside the adsorption bed and then to improve the radioxenon decontamination factor of the adsorption system. 
To put into practice this technique for the IRE case, it is important to identify all the possible pathways of xenon release all along the production process. Subsequently, the constraints related to the actual configuration of the facility and its ventilation system, have also to be taken into account (e.g., high ventilation flow rate in the hot cells, several release points within the building). The flow diagram of a xenon retention system identified as a possible solution for the treatment of the radioxenon emissions from IRE is shown Figure 3.4.

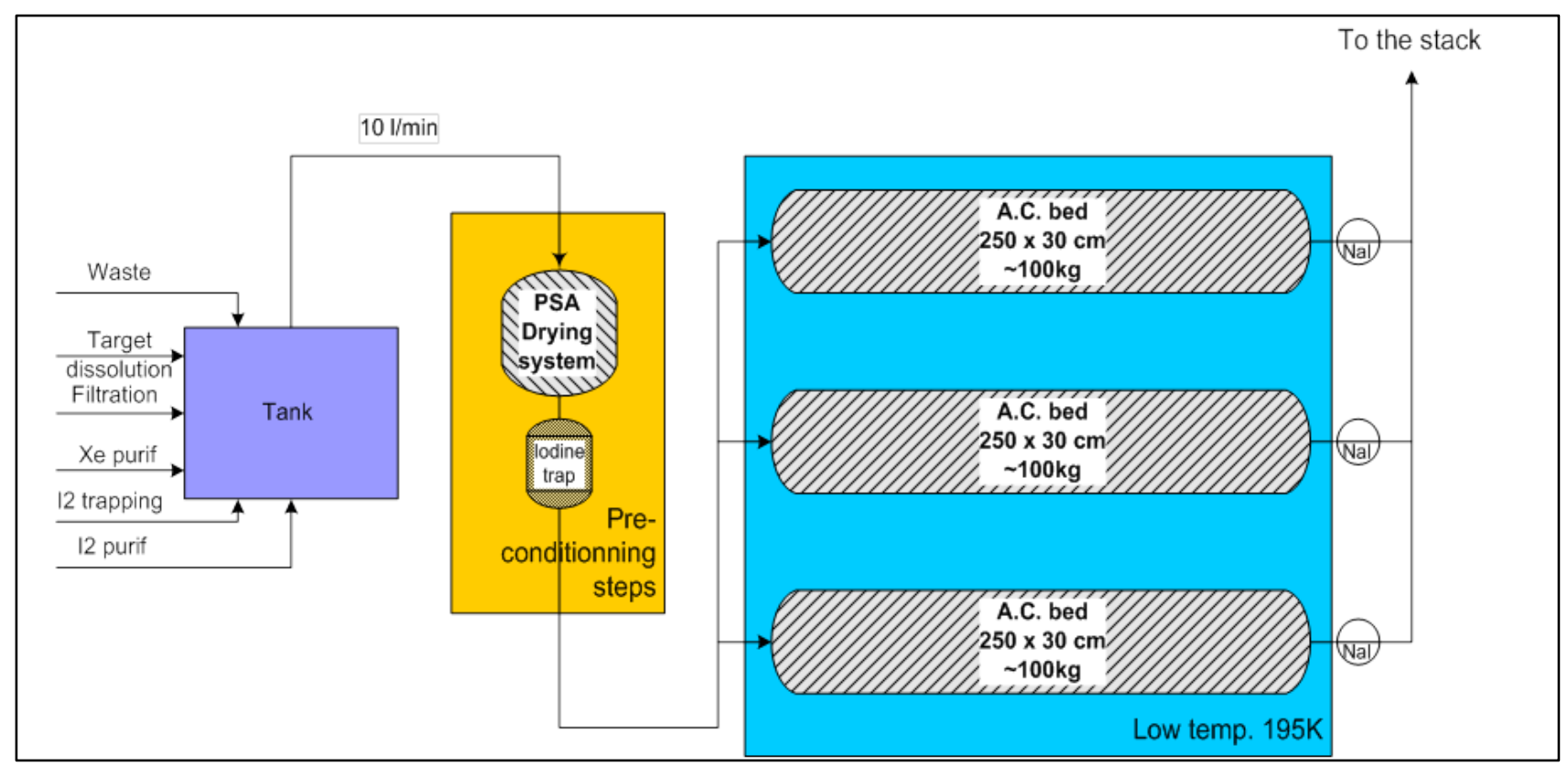

Figure 3.4. Flow diagram of the Fleurus xenon-emission control system.

The xenon adsorption system is divided in three parts. Firstly, all of the xenon-contaminated process gases are transferred into a holding tank. These process gases come from different steps in the production process (e.g., targets dissolution, iodine recovery and purification steps, liquid wastes, and so on.) Secondly, the xenon-contaminated off-gases mixture is purified in order to remove the impurities from the carrier gas that could interfere with the xenon adsorption process. This pre-conditioning step consists of two stages: (1) removal of water and carbon dioxide traces and, (2) removal of iodine. Thirdly, the radioxenon retention is performed using a single column of activated carbon in triplicate for practical and safety reasons. The temperature of the adsorption bed is $195^{\circ} \mathrm{K}$ (in order to reduce as much as possible the size of the bed by increasing the efficiency of the adsorption process). A total flow rate of 10 liters per minute is employed inside the adsorption bed, with retention time of xenon of about 45 days. The decontamination factor for ${ }^{133} \mathrm{Xe}$ can be up to 400 under these conditions. When the xenon breakthrough 
occurs, the activity concentrations of xenon isotopes have decreased sufficiently to be released via the conventional ventilation system to the atmosphere.

\subsection{Operations at Petten}

At the ${ }^{99}$ Mo production facility in Petten, Netherlands (operating under the license of the former Nuclear Research Center Karlsruhe, now Karlsruhe Institute of Technology, KIT) very low ${ }^{133}$ Xe releases have been achieved from large-scale production facilities by a combination of selective chemical separation processes and efficient off-gas handling technology. Implementation of this modern process by the highly qualified on-site operation team is also a contributing factor.

The world market ${ }^{99}$ Mo supply share of the Petten facility is estimated as $26 \%$ of a weekly demand of $12,000 \mathrm{Ci}$. This involves receipt at the facility of $680,000 \mathrm{Ci}$ of ${ }^{133} \mathrm{Xe}$, together with the other fission and activation nuclides formed in the targets by reactor irradiation. The annual ${ }^{133} \mathrm{Xe}$ release from the facility is $20 \mathrm{Ci}$, representing just $0.003 \%$ of the total handled amount.

Process and off-gas handling flow sheets of the Karlsruhe production process are depicted in Figures 3.5 - 3.9. The production process and the off-gas treatment are segments of the ${ }^{99}$ Mo production cycle developed and demonstrated at KIT.

The production process is initiated by the alkaline digestion of the irradiated aluminum-clad UAlx targets. The generated hydrogen is directly oxidized to water by passing through heated copper oxide. The alkaline filtrate undergoes a series of chemical purification steps completed by the thermal sublimation of molybdenum (VI) oxide. Figure 3.5 shows a simplified scheme of the purification process. Dissolver offgases are handled as depicted in Figure 3.6 while hot-cell and equipment ventilation systems are treated as depicted in Figure 3.7. The overall off-gas treatment system, including the recycling of the generated highly contaminated U-residues and the retargeting of the purified fuel, is illustrated in Figure 3.8.

The final treatment of off-gases is based on mass separation of the heavy xenon isotopes from the far lighter carrier-gas stream (preferably helium, or nitrogen), as illustrated in Figure 3.9. The xenon stream is fed through a stainless steel tube which is divided into segments by meshed materials which reduce turbulence and allow the xenon to sink down to the lower segments and can be separated if needed. The off-gas stream which leaves the separation tube then contains relatively little xenon. 


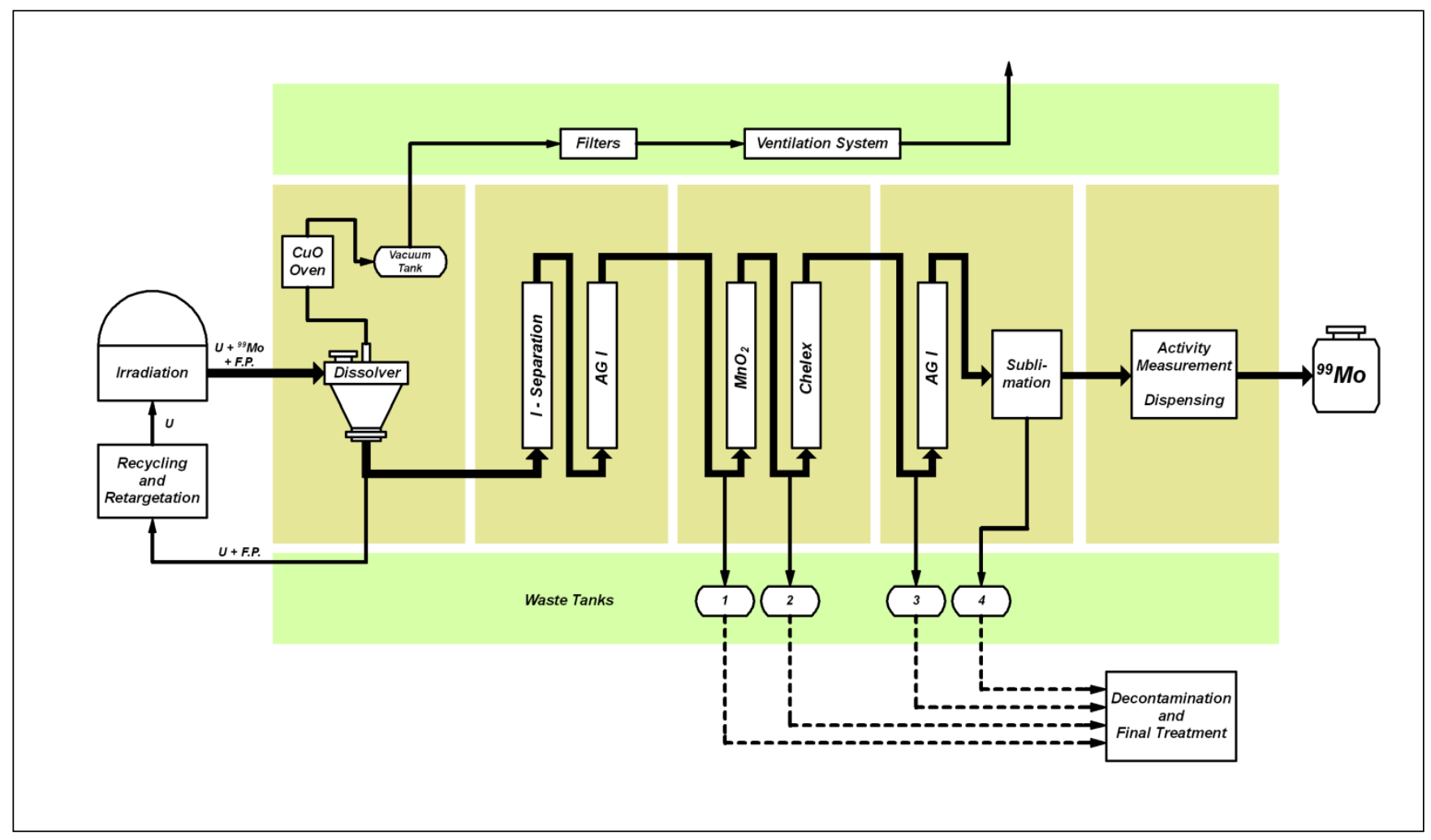

Figure 3.5. A schematic diagram of the Petten ${ }^{99}$ Mo production process.

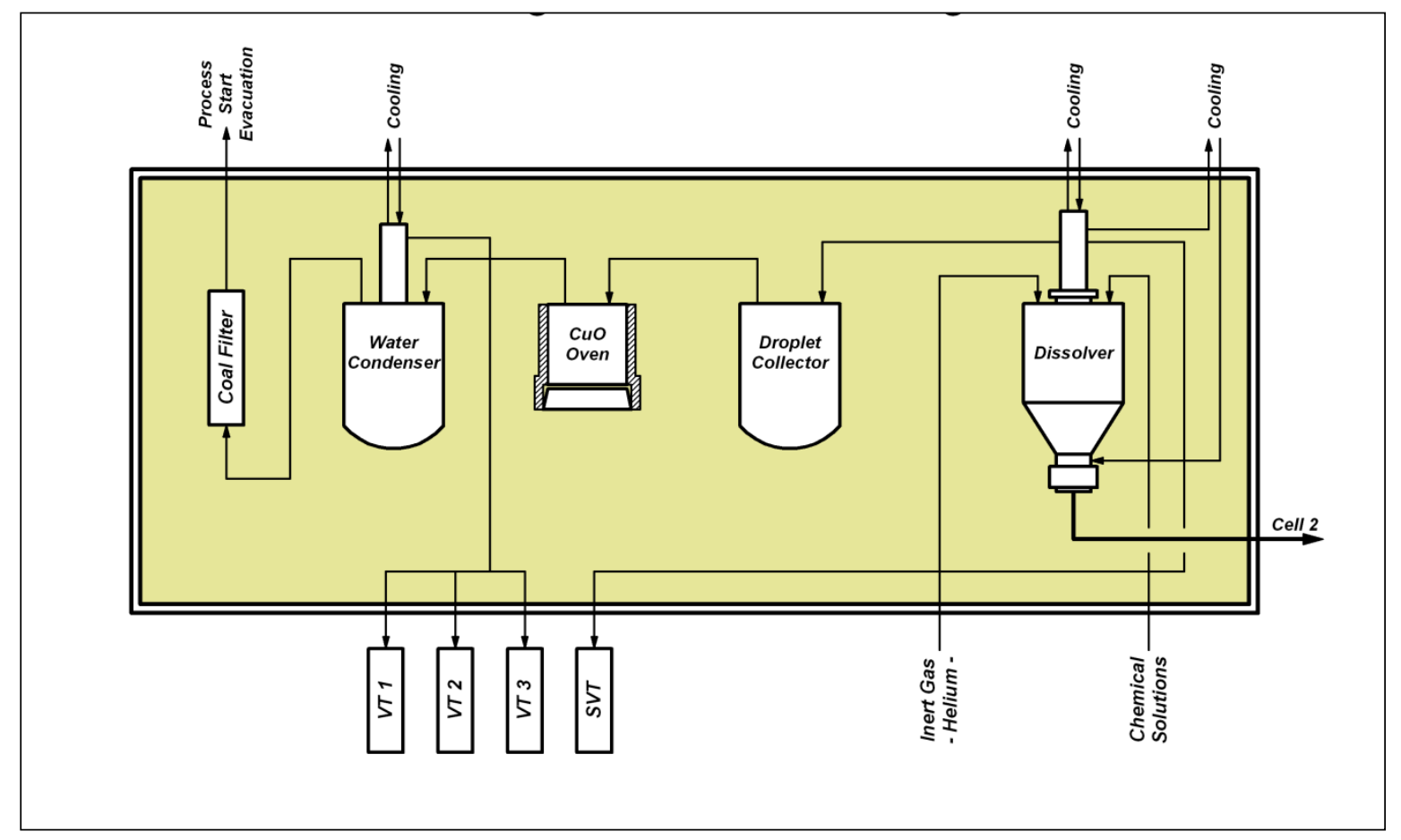

Figure 3.6. Dissolver off-gas handling at Petten. 


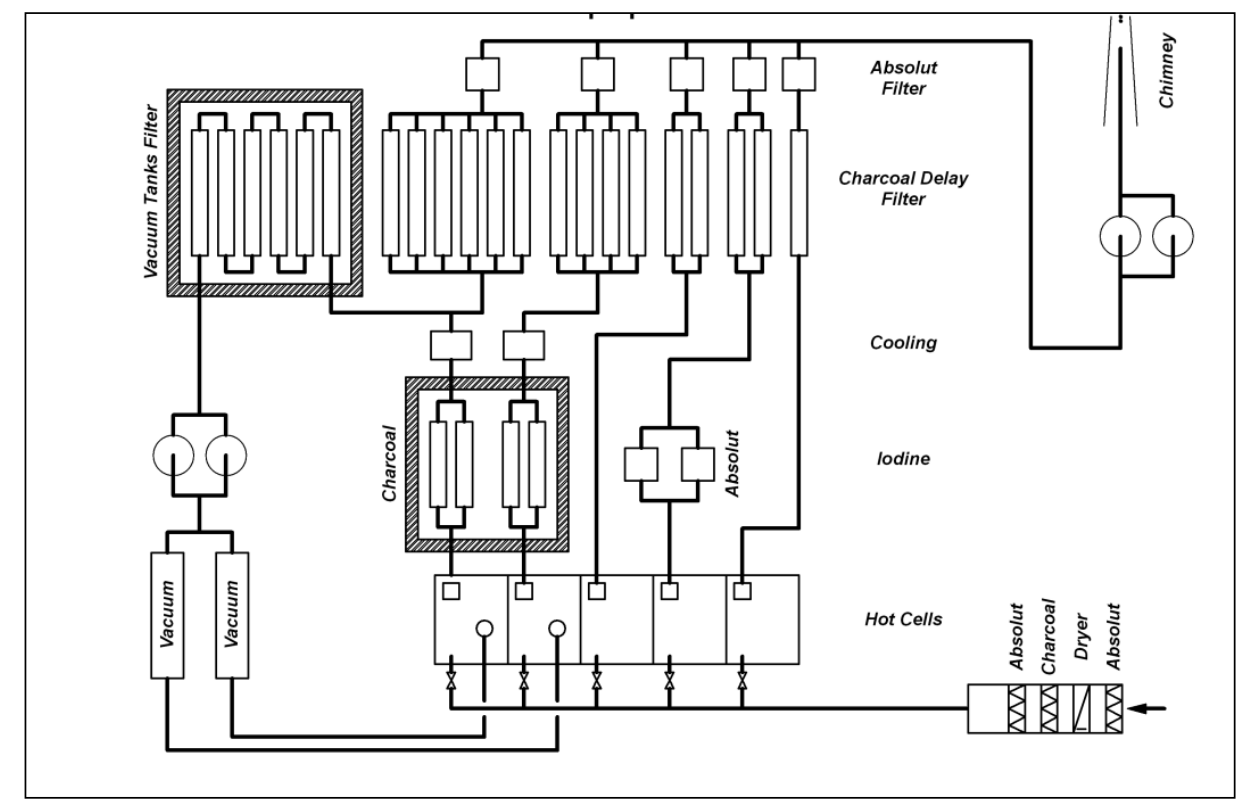

Figure 3.7. Cell and equipment ventilation at Petten.

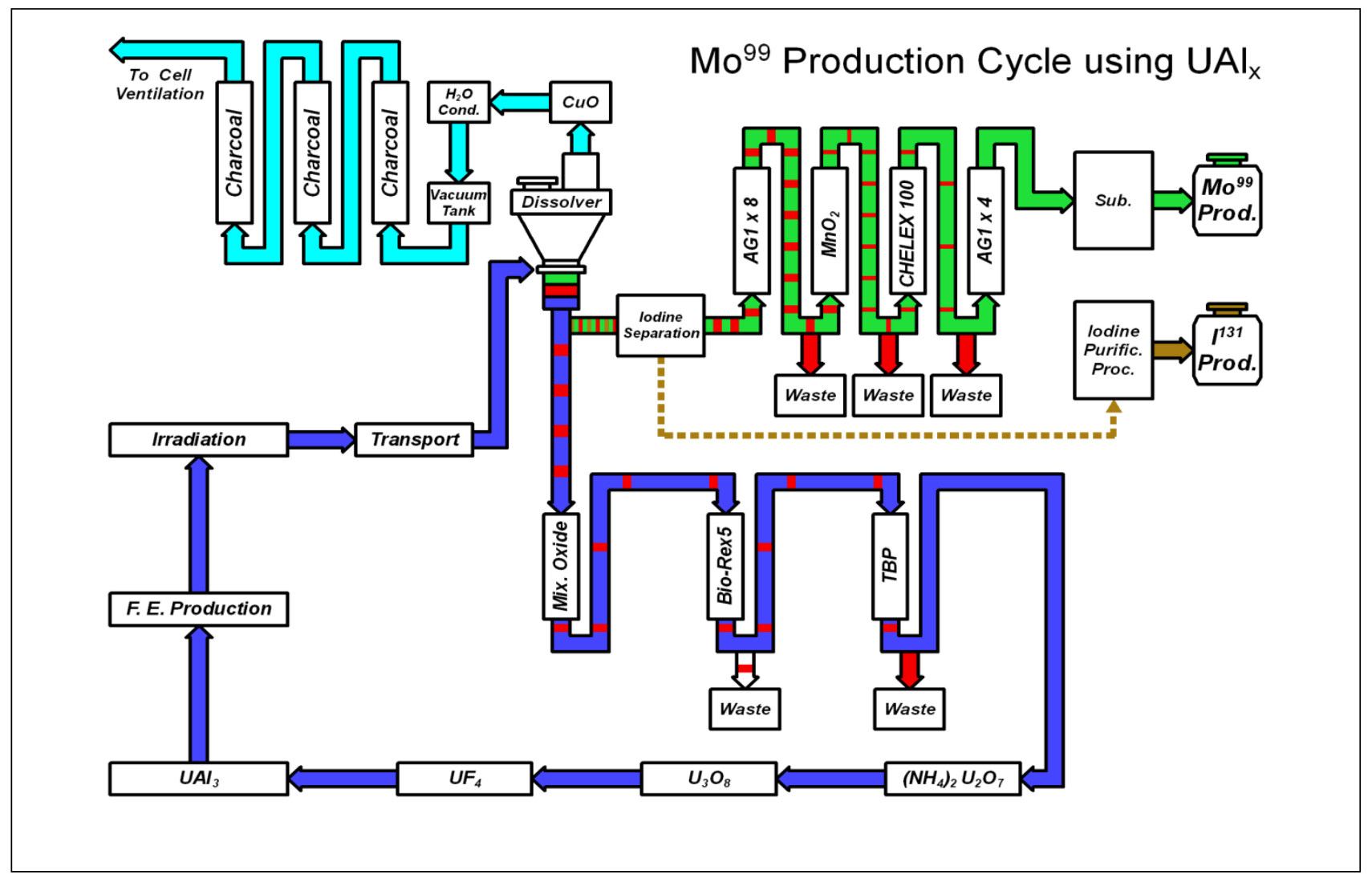


Figure 3.8. Overall ${ }^{99}$ Mo production cycle at Petten.

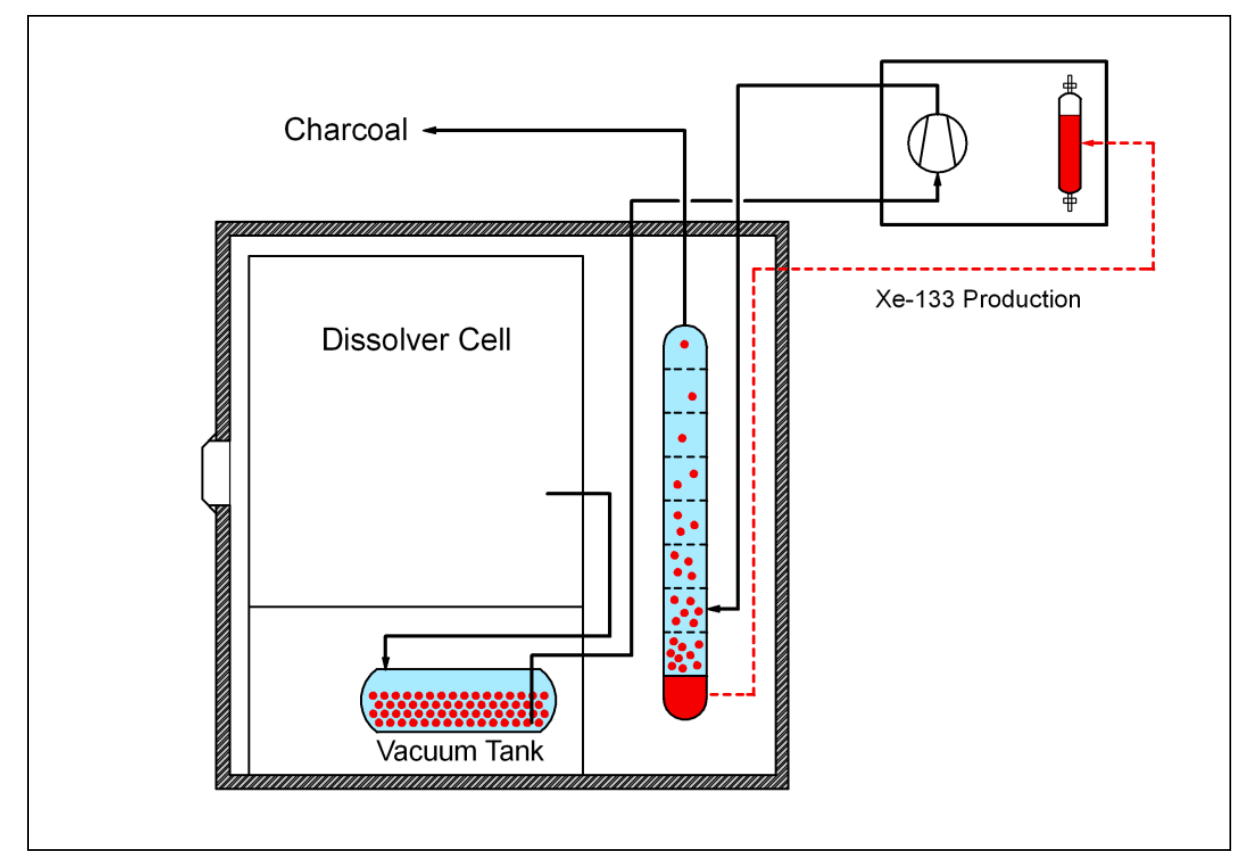

Figure 3.9. Xenon enrichment of the dissolver off-gas.

\subsection{Recent and planned activities at IPFs}

Discussions of current experience and recent or planned developments at IPFs were based on presentations by Michael Druce (ANSTO, Australia), Mohammad Sabzian (Shahid Beheshti University, Iran), Budi Briyatmoko (NAEA, Indonesia) and Greg Piefer (SHINE Medical Technologies, USA).

\subsection{Australia}

Production volume at the ANSTO plant in Australia has increased to 1000 six-day Curies, in four production runs per week, representing $9 \%$ of world demand. The overall ${ }^{99}$ Mo production process involves steps of irradiation, dissolution, separation and purification as depicted schematically in Figure 4.1. As mentioned above, this process involves trapping noble gases and holding in storage tanks for six weeks, retention of radio-iodines on ion-exchange columns, and uranium waste is stored as dry cake. Liquid wastes are treated separately depending on whether of intermediate or low level radioactivity. Intermediate-level wastes containing long-lived nuclides such as ${ }^{90} \mathrm{Sr}$ and ${ }^{137} \mathrm{Cs}$ are stored in caustic solution for one year before transfer to a "waste-tank farm” for final treatment. Low-level wastes are 
stored for nine months before transfer to the farm. All gaseous emissions are collected in pre-evacuated under-floor tanks and held there for five weeks before venting. Venting occurs through configurable charcoal traps which may be connected in series or parallel, depending on demand, as illustrated in Figure 4.2.

Practical issues arising in the operation of this plant which can contribute to xenon emissions, include:

- failing hoses, leaks in hose connections (problem solved by use of braided stainless-steel hosing instead of plastic);

- release of gas during disconnection of ion-exchange columns, and slow evolution of gas during column storage - solved using spring-loaded valves and use of a storage container fitted with rubber seals;

- loss of vacuum, requiring re-evacuation the buffer tanks - solved by fitting a second buffer tank to ensure sufficient vacuum is always available. Consideration is being given to a third.

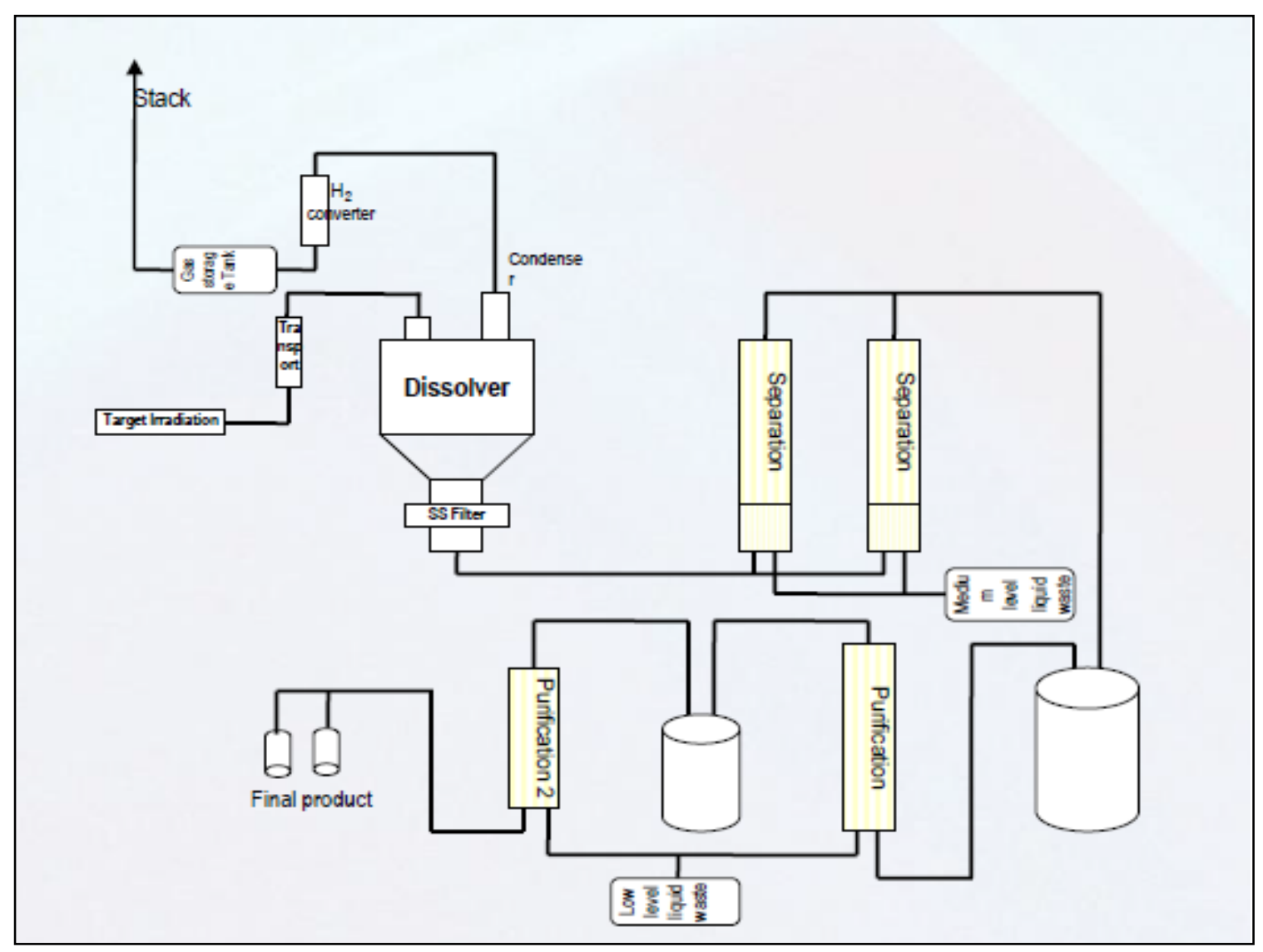

Figure 4.1. The ANSTO ${ }^{99}$ Mo production process. 


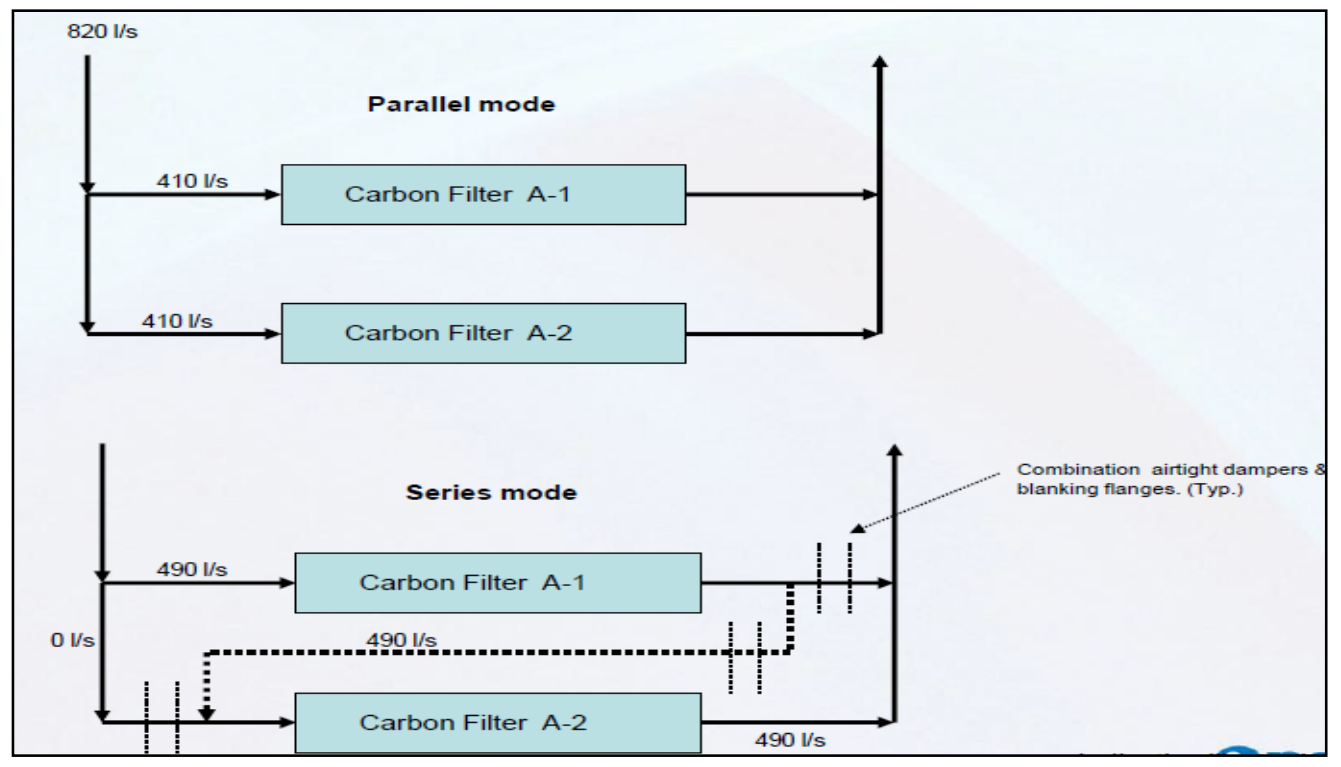

Figure 4.2. Configurable carbon filters deployed at ANSTO.

\subsection{Iran}

The Tehran Research Reactor (TRR) is a $5 \mathrm{MW}_{\text {Th }}$ pool-type reactor, normally operated at $3 \mathrm{MW}$, using 20\% LEU. Use of the reactor is linked with the Atomic Energy Organization of Iran (AEOI) for use in the fields of nuclear medicine and agricultural research. A cyclotron accelerator was added to the facility in 1994. The facility produces radiopharmaceuticals and stable isotopes for medical application, provides oversight of radiotherapy centers, provides design and calibration services for dosemeters, and conducts research with seed irradiation.

Molybdenum-99 is produced by either thermal-neutron irradiation of $\mathrm{MoO}_{3}$, or by separation of fission products from irradiated uranium targets. There is a need for about $20 \mathrm{Ci}$ per week in Iranian medical centers. Target irradiation time is seven days (the facility operates on seven-day cycles) producing about $37 \mathrm{Ci}^{99}$ Mo per cycle.

Iodine-131 is also widely used in Iran, and is produced either by irradiation of tellurium targets via the reaction ${ }^{130} \mathrm{Te}(\mathrm{n}, \gamma){ }^{131} \mathrm{Te} \rightarrow$ I, or by irradiation of uranium targets. 


\subsection{Indonesia}

Since 1995, Indonesia has had cooperation with ANL to develop ${ }^{99}$ Mo production using LEU foil targets, and since 2005 has taken part in an IAEA CRP for 'Developing techniques for small-scale indigenous ${ }^{99}$ Mo production using LEU fission or neutron activation'. Research collaboration between the National Nuclear Energy Agency of Indonesia (BATAN) and ANL has focused its activities on the conversion from HEU to LEU targets for ${ }^{99}$ Mo production. This has involved activities with the Nuclear Fuel Technology Center (PTBN) to study the design and fabrication of targets; the Research Reactor Technology Center to study irradiation aspects; and the Radioisotope and Radiopharmaceutical Development Centre to study the development ${ }^{99} \mathrm{Mo}$ production through the Cintichem process. Production using HEU targets will soon finish.

LEU target fabrication involves cold and hot rolling of LEU plate as a raw material. The resulting foil is wrapped, with a fission recoil barrier, around the inner tubes which are then placed in an outer tube the ends of which are then welded closed, as show in Figure 4.3.
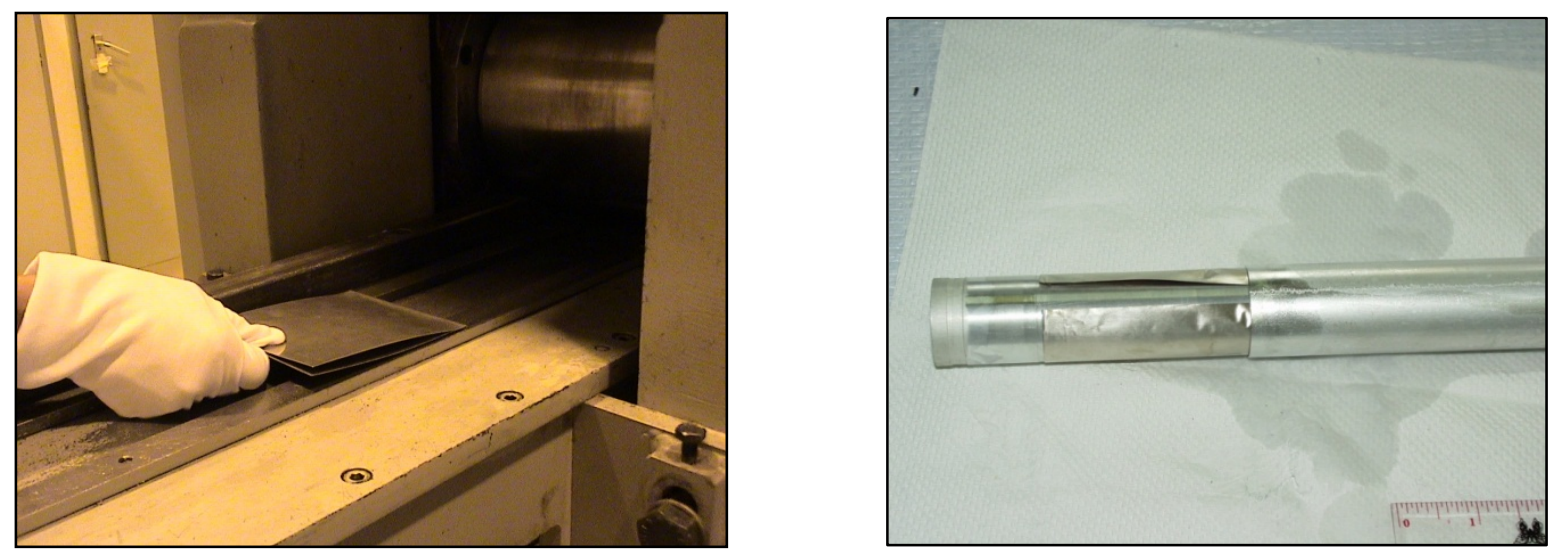

Figure 4.3. Fabrication of LEU targets in Indonesia.

The reactor used for radioisotope production is the RSG GAS facility in Serpong, with an installed power $30 \mathrm{MW}$ and operational power of $15 \mathrm{MW}$. After irradiation, the LEU foil target is disassembled in a hot cell and dissolved in nitric acid. Iodine gas is trapped by a cold-finger.

Thirty-six production runs are performed per year, although this could be doubled to meet demand. Customers include Malaysia (5 - $10 \mathrm{Ci}$ per week), Japan (60 Ci per week, although Indonesia could only 
supply $20 \mathrm{Ci}$ ), Bangladesh (5 Ci per week), and Vietnam (5 Ci per 2 weeks). National consumption of ${ }^{99} \mathrm{Mo}$ is $7 \mathrm{Ci}$ per week.

\subsection{Use of a D/T neutron source}

SHINE Medical technologies and its partners are developing an accelerator system which will produce high-specific-activity medical isotopes. The technology is based on production of neutrons in a D-T source, used to irradiate a LEU solution where they multiply sub-critically and create medical isotopes. The initial plant is planned to produce ${ }^{99} \mathrm{Mo}$ at a rate of about 3,000 six-day Ci per week. Full-scale operation is planned from 2015 (with a demonstration system planned for installation at Los Alamos in 2013).

In operation, deuterium gas flows into an ion source where it is ionized by microwave radiation; an accelerator (300 keV) then pushes the $\mathrm{D}$ ions into a target chamber where reactions with tritium gas create neutrons ( $>10^{9} \mathrm{n} / \mathrm{s}$ per watt). The high-energy neutrons multiply, (n, $2 \mathrm{n}$ ), on a beryllium target. Mature accelerator technology, inherent safety, use of LEU (19.5\%), reduced radioactive waste, and improved chemical extraction efficiency through use of an aqueous target are all recognized benefits of this system.

The pilot plant will produce approximately $100 \mathrm{~kW}$ of fission power and 500 6-day Ci ${ }^{99}$ Mo per week. Iodine activity at the end of a batch under these conditions would be approximately $2000 \mathrm{Ci}$, with radioxenon activities of about $5500 \mathrm{Ci}$ of ${ }^{133} \mathrm{Xe}$ and $5100 \mathrm{Ci}$ of ${ }^{135} \mathrm{Xe}$. These are production numbers only and do not account for trapping.

\subsection{Experience in monitoring IPF emissions}

Presentations by Emmy Hoffmann (ANSTO, Australia), Richard DeCaire (Nordion, Canada), Benoit Deconninck (IRE-Elit, Belgium), Michel Rotty (Canberra Industries), Mika Nikkinen (CTBTO) and Judah Friese (PNNL, USA) formed the basis of discussion of IPF monitoring experience, supported by a poster by Johan Camps (SCK-CEN, Belgium).

\subsection{Monitoring ANSTO stack releases}


Systems for monitoring ANSTO stack releases are under continual development and improvement. At present a low-resolution system uses a $\mathrm{NaI}$ detector viewing a $100 \mathrm{~mL}$ flow-through chamber as shown in Figure 5.1.

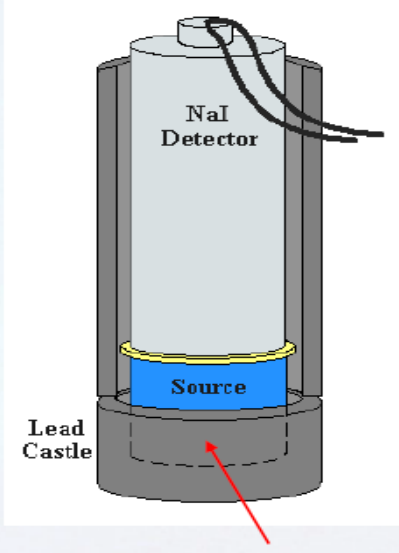

Figure 5.1. Low-resolution ANSTO stack monitor, with detector viewing a $100 \mathrm{~mL}$ chamber.

A prototype high-resolution system is under development using a Marinelli beaker flow chamber, as shown in Figure 5.2. The final version will have electrical cooling and lead shielding, with a 4L sealed Marinelli beaker and a flow rate of $0.5-2 \mathrm{~L} / \mathrm{min}$.

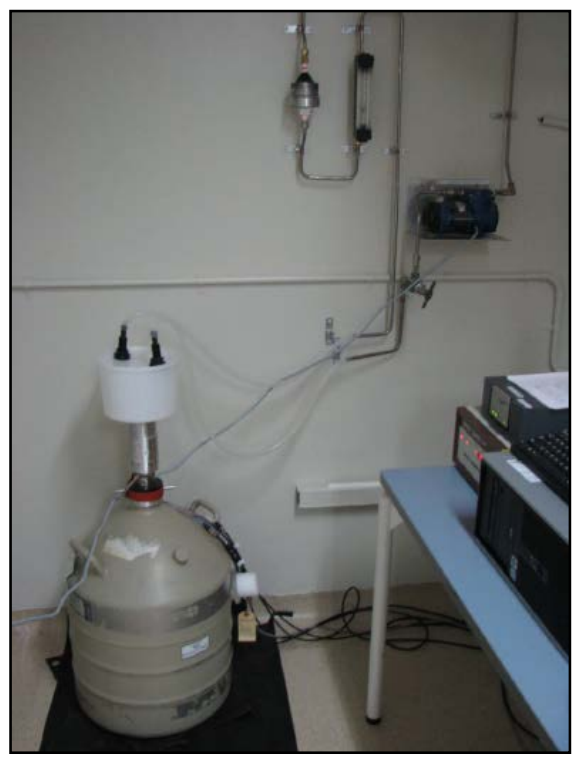

Figure 5.2. ANSTO prototype high-resolution stack monitor. 


\subsection{Release monitoring and mitigation at the Nordion plant}

The Nordion plant has an active ventilation monitoring system, as depicted in Figure 5.3. Dose rate is continually monitored from the trench filters, duct air is monitored before the last series of filters, and beta and gamma activity are actively and passively monitored at the stacks. Stack xenon levels are monitored before the final charcoal absorber.

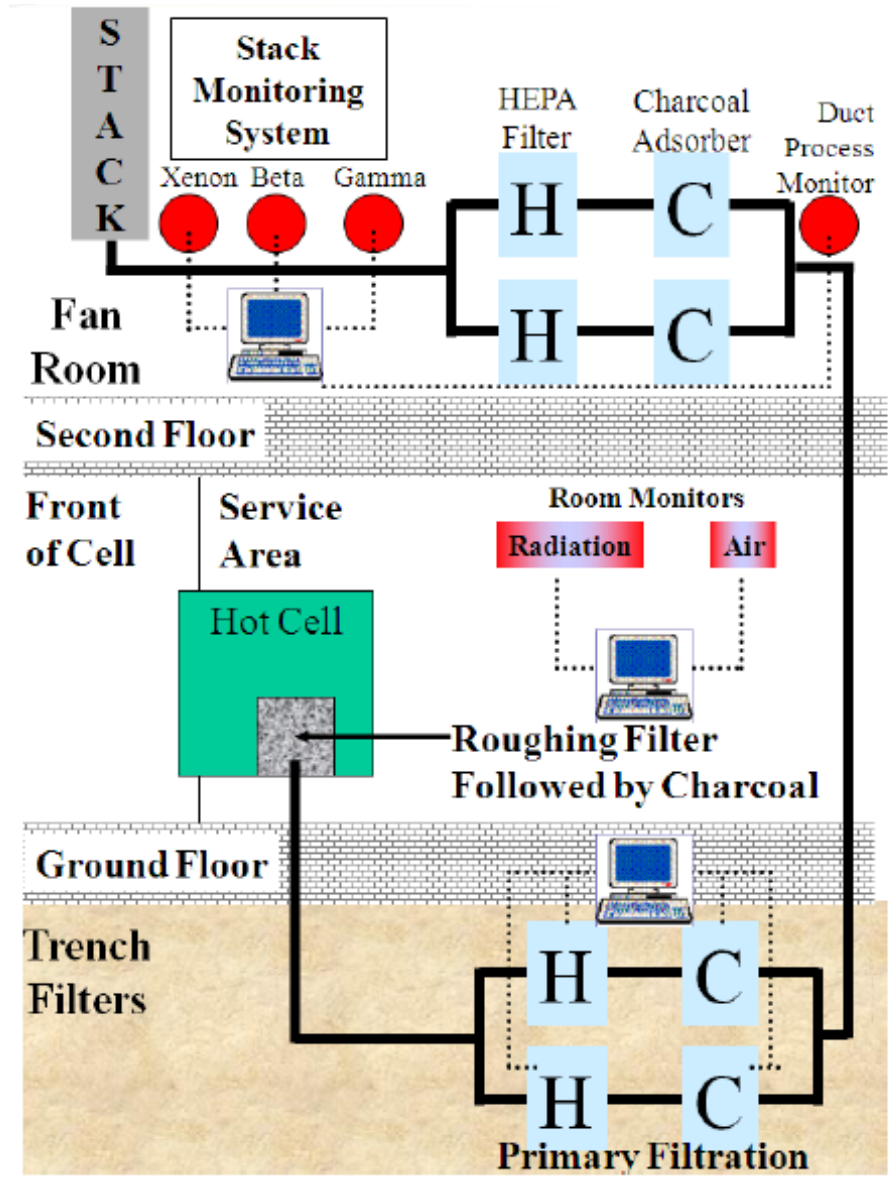

Figure 5.3. The ventilation monitoring system at the Nordion plant.

Xenon release mitigation at Nordion involves a series of molecular sieve and activated carbon filters as shown in Figure 5.4. 

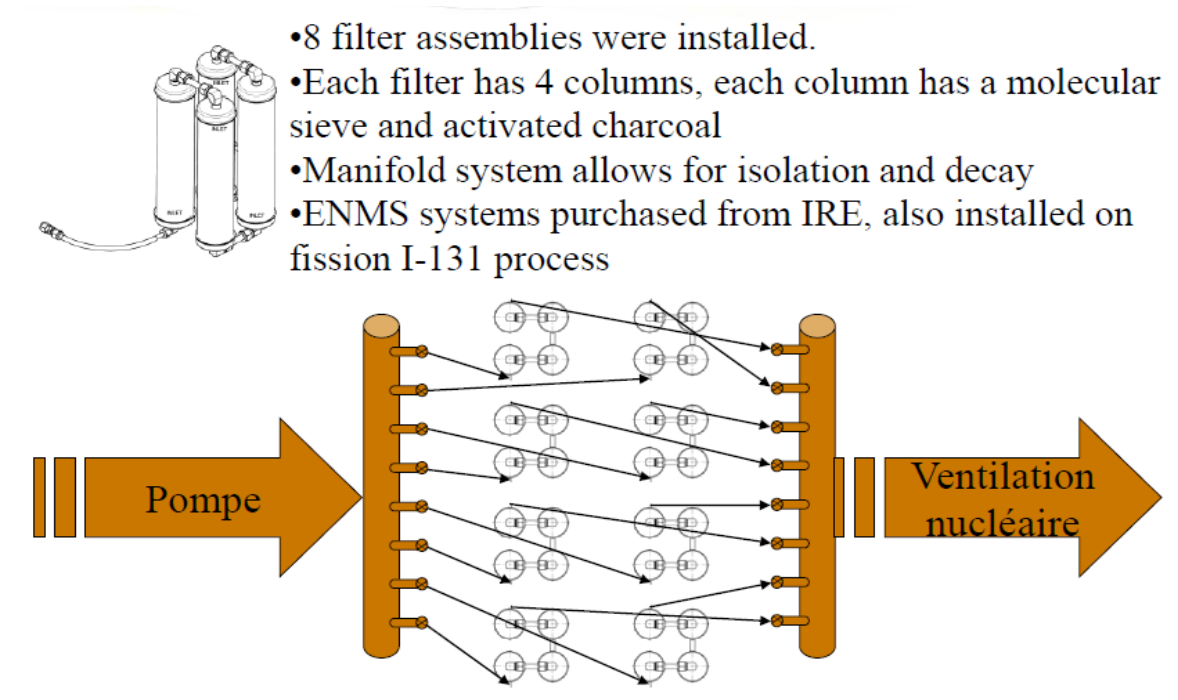

Figure 5.4. Xenon trapping system employed at the Nordion plant.

\subsection{Stack monitoring at IRE}

The Institute for Radio-Element (IRE, Belgium) produces bulk ${ }^{99}$ Mo and ${ }^{131}$ I for medical application, with these nuclides being chemically extracted from HEU targets activated in reactors. IRE is the largest world producer of ${ }^{131} \mathrm{I}$ and provides at least $50 \%$ of Europe's need for ${ }^{99} \mathrm{Mo}$. In order to improve the measurement and the understanding of the xenon releases, IRE has developed a specific high-resolution monitoring system as described here.

IRE processes targets which have been irradiated for about $150 \mathrm{~h}$, followed by a $30 \mathrm{~h}$ cool-off period. Typically, during a production batch, $\sim 9000 \mathrm{Ci}$ of ${ }^{133} \mathrm{Xe}, 9000 \mathrm{Ci}$ of ${ }^{99} \mathrm{Mo}$ and $\sim 3000 \mathrm{Ci}$ of ${ }^{131} \mathrm{I}$ are produced. The overall process is shown in Figure 5.5. 


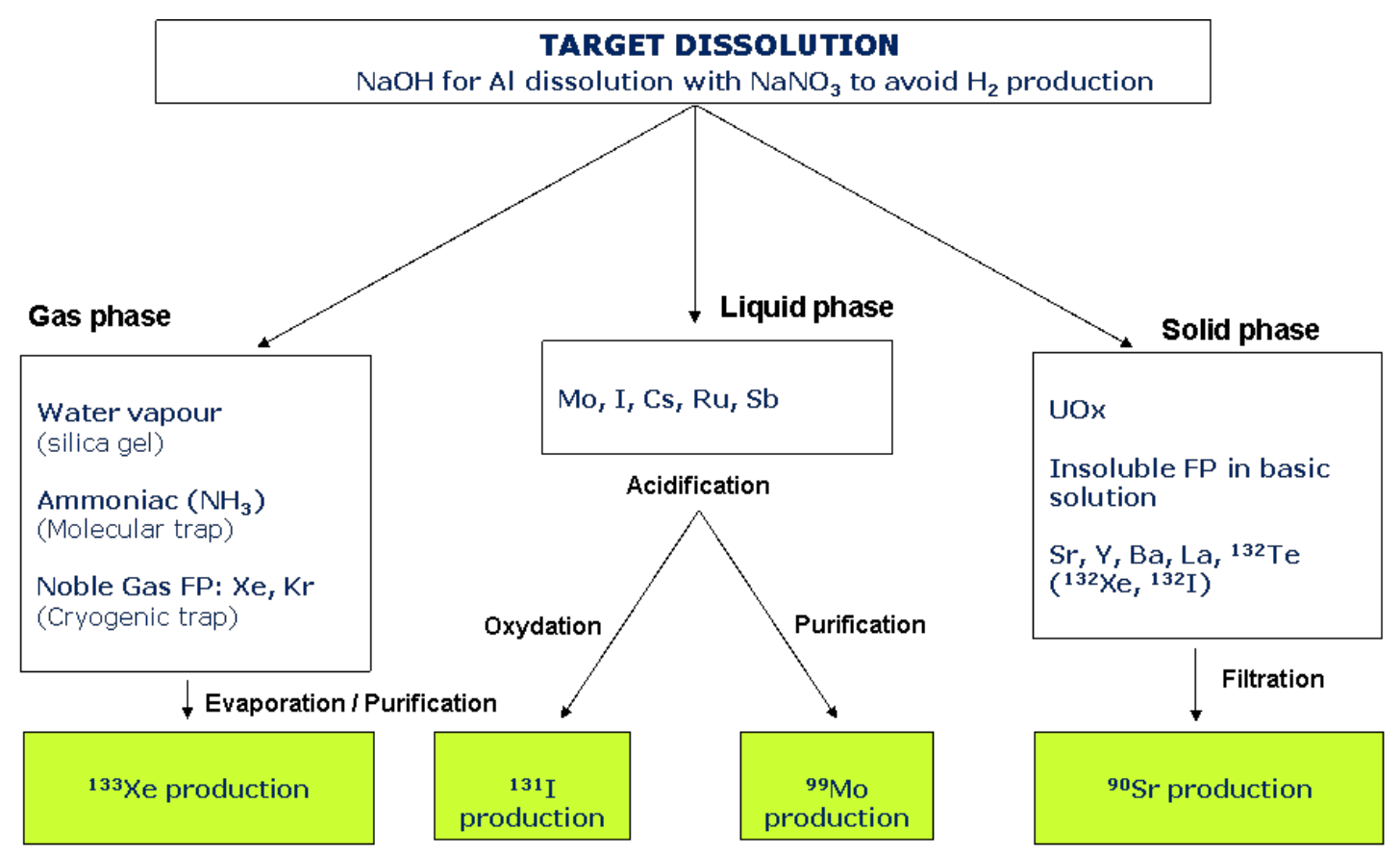

Figure 5.5. Schematic description of IRE production process.

The production facility is equipped with hot cells, glove boxes, laboratories, etc. All of these components are connected to a ventilation system which discharges the gases through a main stack equipped with a monitoring system. Three types of potential releases are monitored in sequence: aerosols, iodine and noble gases. A pumping system continuously samples gases stack emissions. First, the discharge passes through a paper filter to trap particulates. This filter is monitored by a PIPs detector to detect alpha and beta emission from the aerosols. Second, after aerosol filtration, the discharge passes through a charcoal filter where iodine species are trapped. This filter is monitored by a NaI detector coupled to a singlechannel analysis system centred on the $364-\mathrm{keV}$ line of ${ }^{131} \mathrm{I}$. Finally, the remaining discharge fraction, containing mainly noble gases, passes through a chamber equipped with a plastic scintillator which provides gross counting of the radioxenon mix. Although this system gives good results, it has drawbacks that needed to be improved, such as interference by radio-xenon in the iodine channel generating "false alarms” and no possibility of discriminating between radioxenon isotopes.

In order to improve the existing system and the understanding of its releases, IRE has developed a high resolution monitoring system as depicted in Figure 5.6. Aerosol monitoring is based on the same principle as the existing system, with a filter and PIPs detector, but with a second PIPs installed to measure the background. Iodine and noble gases go through a double charcoal cartridge viewed by an 
HPGe detector. Calibration is performed by Monte Carlo simulation confirmed by spiked cartridge analysis.

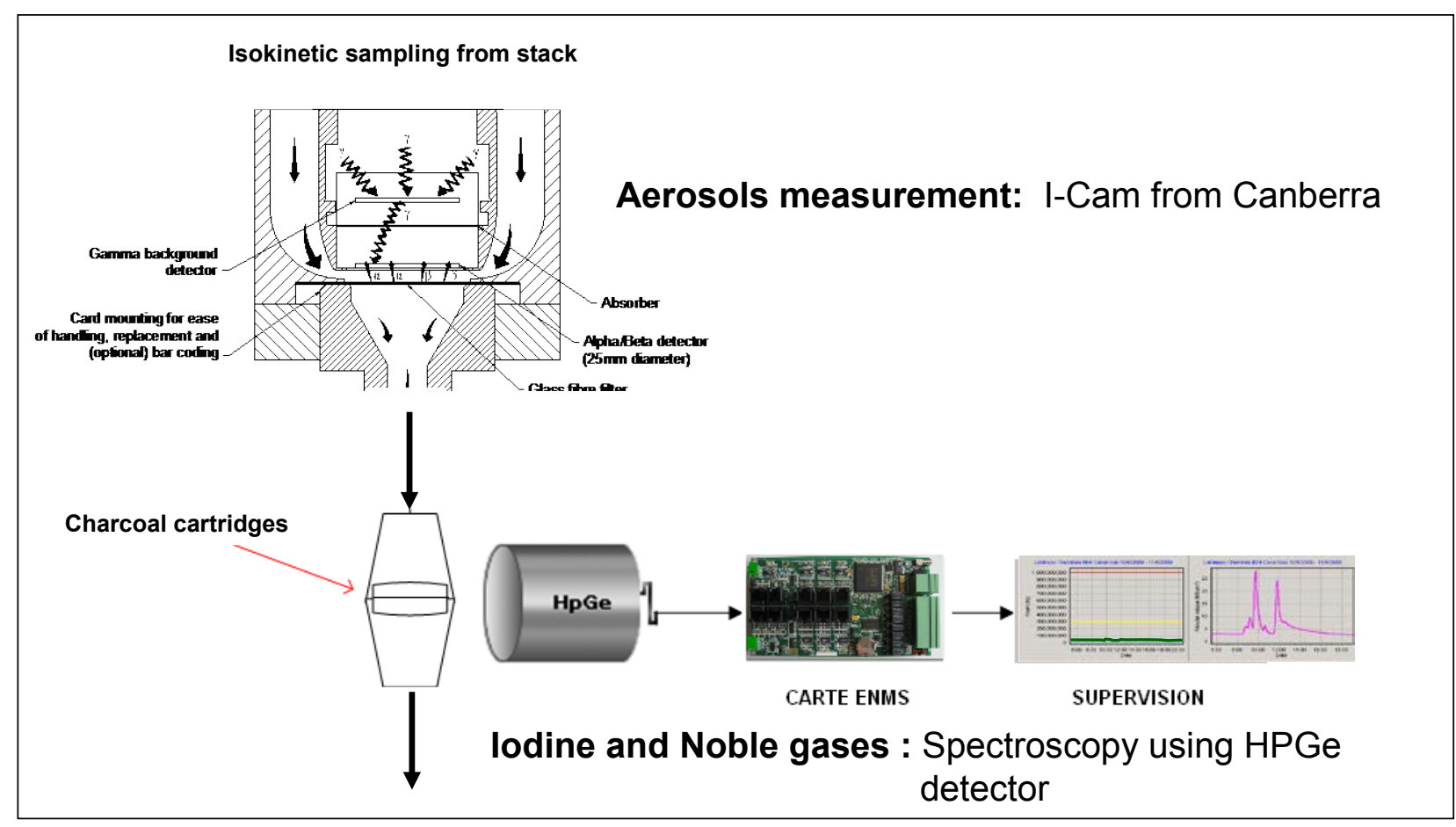

Figure 5.6. High-resolution monitoring system developed for IRE main stack.

\subsection{Characterization of radio-xenon discharges in Belgium}

The following sources of radioxenon emission in Belgium are identified (with a summary in Table 5.1):

- The Nuclear Power Plants of Doel (4 PWRs, $2911 \mathrm{MW}_{\mathrm{e}}$ ) and Tihange (3 PWRs, $2985 \mathrm{MW}_{\mathrm{e}}$ ). Release quantities are given in Table 5.1, based on the NPPs' yearly environmental report, averaged for the period 2005 - 2009. The large difference between Doel and Tihange is caused by a different treatment of the noble gases.

- The IRE IPF in Fleurus. Table 5.1 values are based on ORIGEN (Oak Ridge Isotope GENeration code) calculations, and are typical for 2009. 
- The Belgian Nuclear Research Centre (SCK•CEN) located in Mol. Table 5.1 values are based on measurements over 2005-2007.

- Nuclear medicine. The main radioxenon isotope released from nuclear medicine activities in Belgium is ${ }^{131 \mathrm{~m}}$ Xe originating from the decay of ${ }^{131} \mathrm{I}$ after treatment of the thyroid. Based on data from a survey by the Belgian Association of Nuclear Medicine yearly at least 330 patients are treated for thyroid cancer and 3360 for other thyroid diseases. Taking into account the branching ratio of 1.1\% for the decay of ${ }^{131} \mathrm{I}$ to ${ }^{131 \mathrm{~m}} \mathrm{Xe}$ and the average administered activities the total estimated ${ }^{131 \mathrm{~m}} \mathrm{Xe}$ activity from nuclear medicine procedures is estimated to be $>5 \times 10^{10} \mathrm{~Bq}$.

\begin{tabular}{|llllll|}
\hline & $\mathrm{Xe}-133$ & $\mathrm{Xe}-135$ & $\mathrm{Xe}-133 \mathrm{~m}$ & $\mathrm{Xe}-135 \mathrm{~m}$ & $\mathrm{Xe}-131 \mathrm{~m}$ \\
\hline Tihange & $1.45 \mathrm{E}+13$ & $8.55 \mathrm{E}+11$ & & & \\
\hline Doel & $2.84 \mathrm{E}+10$ & $9.44 \mathrm{E}+09$ & & & \\
\hline IRE & $1.31 \mathrm{E}+15$ & $1.34 \mathrm{E}+14$ & $5.10 \mathrm{E}+13$ & $3.00 \mathrm{E}+12$ & $1.50 \mathrm{E}+12$ \\
\hline SCK·CEN & $5.66 \mathrm{E}+12$ & & & & \\
\hline Nucl. med & & & & & $>5.00 \mathrm{E}+10$ \\
\hline
\end{tabular}

Table 5.1. Summary of annual released activities (Bq) of radio-xenon isotopes in Belgium.

These releases are summarised graphically in Figure 5.7.

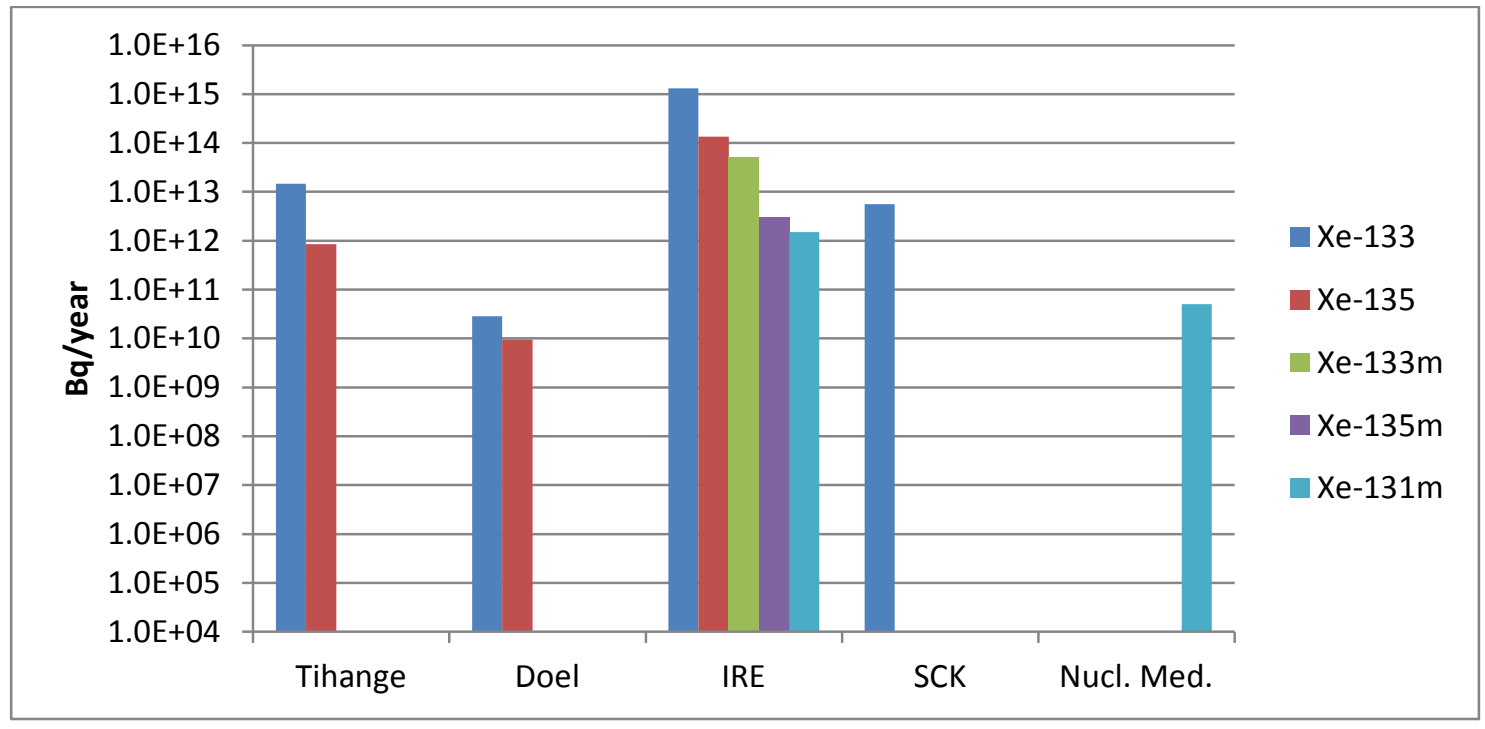

Figure 5.7. Xenon isotope releases from sources identified in Belgium. 
The average air concentration of the most dominant xenon isotope (Xe-133) was calculated around each facility for the different sources identified in Belgium, using the IFDM atmospheric dispersion model and a full year of meteorological data. Results are illustrated in Figure 5.8.

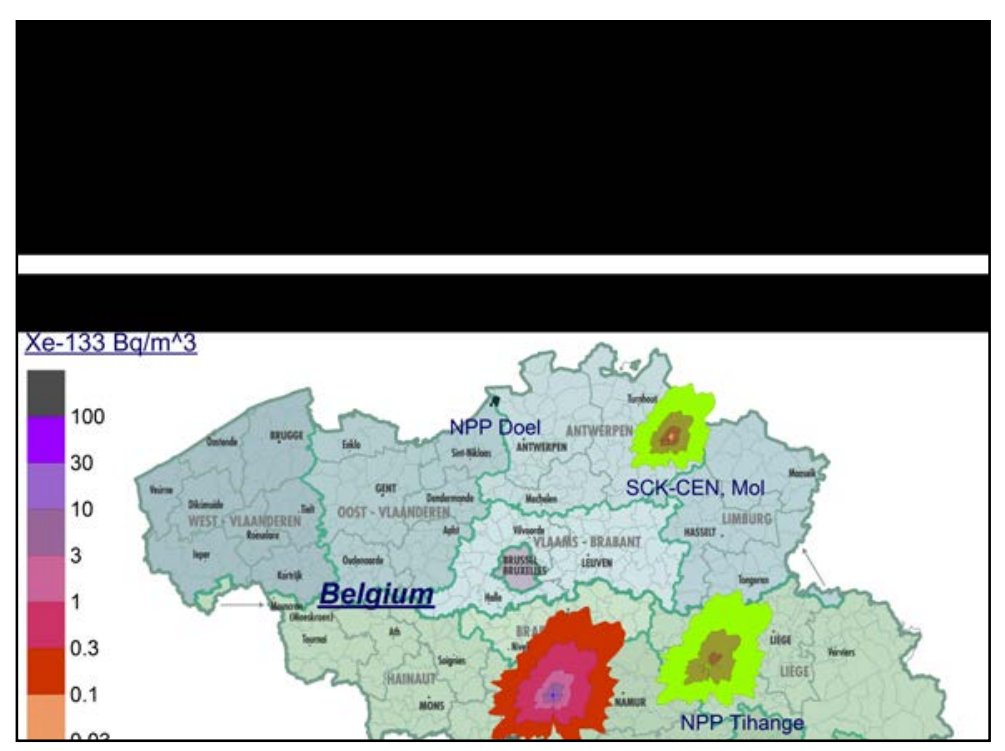

Figure 5.8. Average air concentration of ${ }^{133} \mathrm{Xe}$ around Belgian facilities.

Based on this modeling, average concentrations of ${ }^{133} \mathrm{Xe}$ (and the other isotopes) in the close proximity of each facility is dominated by the release of that facility (except for Doel, where concentrations $\leq$ global ${ }^{133} \mathrm{Xe}$ background). Concentrations around Tihange are reduced relative to the other facilities by the higher emission stack (160 m compared to $60 \mathrm{~m}$ ). The distribution of ${ }^{131 \mathrm{~m}} \mathrm{Xe}$ releases from nuclear medicine procedures follows the distribution of the population/hospital density across the country. This implies that in large cities at large distances from the IRE facility, the average ${ }^{131 \mathrm{~m}}$ Xe concentration can be expected to be dominated by nuclear medicine procedures. The radiological consequences of these atmospheric emissions are minimal: the maximum air concentration of $96.6 \mathrm{~Bq} \mathrm{~m}{ }^{-3}$ corresponds to an effective dose of $4.2 \mu \mathrm{Sv} \mathrm{y}^{-1}$. 


\subsection{Design features of stack monitoring systems}

As indicated above, monitoring systems deployed at IPFs are variable. The number of such plants is growing, each facility is regulated differently, and there are different infrastructures and process types at each facility.

A degree of standardization in stack monitoring would be helpful in enabling meaningful comparisons and would affect estimations. In order to achieve this standardization, the following issues will need to be addressed going forward: monitoring technology, region-of-interest vs. spectral peak fitting, infrastructure requirements, interfering radionuclides, access to data, proprietary information, and methods of sharing data and integrating it with the IDC.

A question for further consideration is how these issues may be addressed.

\subsection{Effects of IPFs on CTBT xenon-monitoring stations}

The CTBTO has developed a system known as the "xenon flagger" to show the degree of influence of IPFs on IMS noble-gas stations. The system is based on emissions from known facilities, sourcereceptor-sensitivities, and detection capability, with data coming from point sources (Chalk River, Fleurus, Pelindaba, Petten and ANSTO); area sources (NPPs) and special sources. The calculated flag, on a scale of $0-2$, indicates the expected IPF contribution, as shown in Table 5.2.

\begin{tabular}{|l|l|l|}
\hline Contribution & Flag & \\
\hline contribution $<0.1 \mathrm{mBq} / \mathrm{m} 3$ & 0 & NOT INFLUENCED \\
\hline $\begin{array}{l}0.1 \mathrm{~Bq} / \mathrm{m} 3<\text { contribution }< \\
1 \mathrm{mBq} / \mathrm{m} 3\end{array}$ & 1 & $\begin{array}{l}\text { SLIGHTLY } \\
\text { INFLUENCED }\end{array}$ \\
\hline contribution $>1 \mathrm{mBq} / \mathrm{m} 3$ & 2 & INFLUENCED \\
\hline
\end{tabular}

Table 5.2. The IPF-effect flagging system for IMS stations. 
For existing stations, results of this experimental flagging system are shown in Table 5.3.

\begin{tabular}{|l|l|l|l|}
\hline Not influenced & Rarely influenced & Influenced & $\begin{array}{l}\text { Rich and variable } \\
\text { time series }\end{array}$ \\
\hline AUX04, AUX09 & CAX16 & CNX22 & CAX17 \\
\hline FRX27, FRX29 & CNX20 & NOX49 & DEX33 \\
\hline GBX68 & FRX31 & USX74 & JPX38 \\
\hline NZX46 & MNX45 & XE043 & SEX63 \\
\hline USX77 & RUX58 & & USX75 \\
\hline USX79 & XE001 & & XE061 \\
\hline XE013, XE060 & XE055 & & CAX05 \\
\hline XE065, XE066 & & & \\
\hline
\end{tabular}

Table 5.3. Degrees of influence by IPFs at IMS noble-gas stations.

As shown in Table 5.3, 11 existing stations show significant degrees of influence by IPFs. The flagging system is currently in the prototype development stage, and it will be integrated into the IDC operational environment when ready.

\subsection{Monitoring science and technology}

Monitoring science and technology was addressed through presentations by Steven Biegalski (University of Texas, USA), Eduardo Carranza (CNEA, Argentina), Mohammed Safari (Sharif University of Technology, Iran), Kirill Khrustalev (CTBTO), Ian Hoffman (Health Canada), supported by posters by Helena Burglund (Gammadata, Sweden), Elisabetta Nava (ENEA, Italy) and Michael Schoeppner (University of Roma, Italy).

\subsection{Application of tracers in IPF emission studies}

While suppressing emissions from IPFs would be ideal, it is understood that it might not be practicable to reduce radioxenon emissions to levels below detectable quantities. As a result, a study was conducted to investigate tracers that may be utilized for source identification upon measurement. Both radioactive and stable tracers are evaluated. 
The radioxenon isotope ratio signature expected from a ${ }^{235} \mathrm{U}$-based nuclear explosion is shown in Figure 6.1. The line on the right side shows the activity ratios as a function of time if radioxenon is immediately separated from all parent fission products. The left-hand line represents ratios as a function of time with complete accumulation from fission-product parent decays. The point at the top where both lines meet is the activity ratios at the time of creation $(\mathrm{t}=0)$.

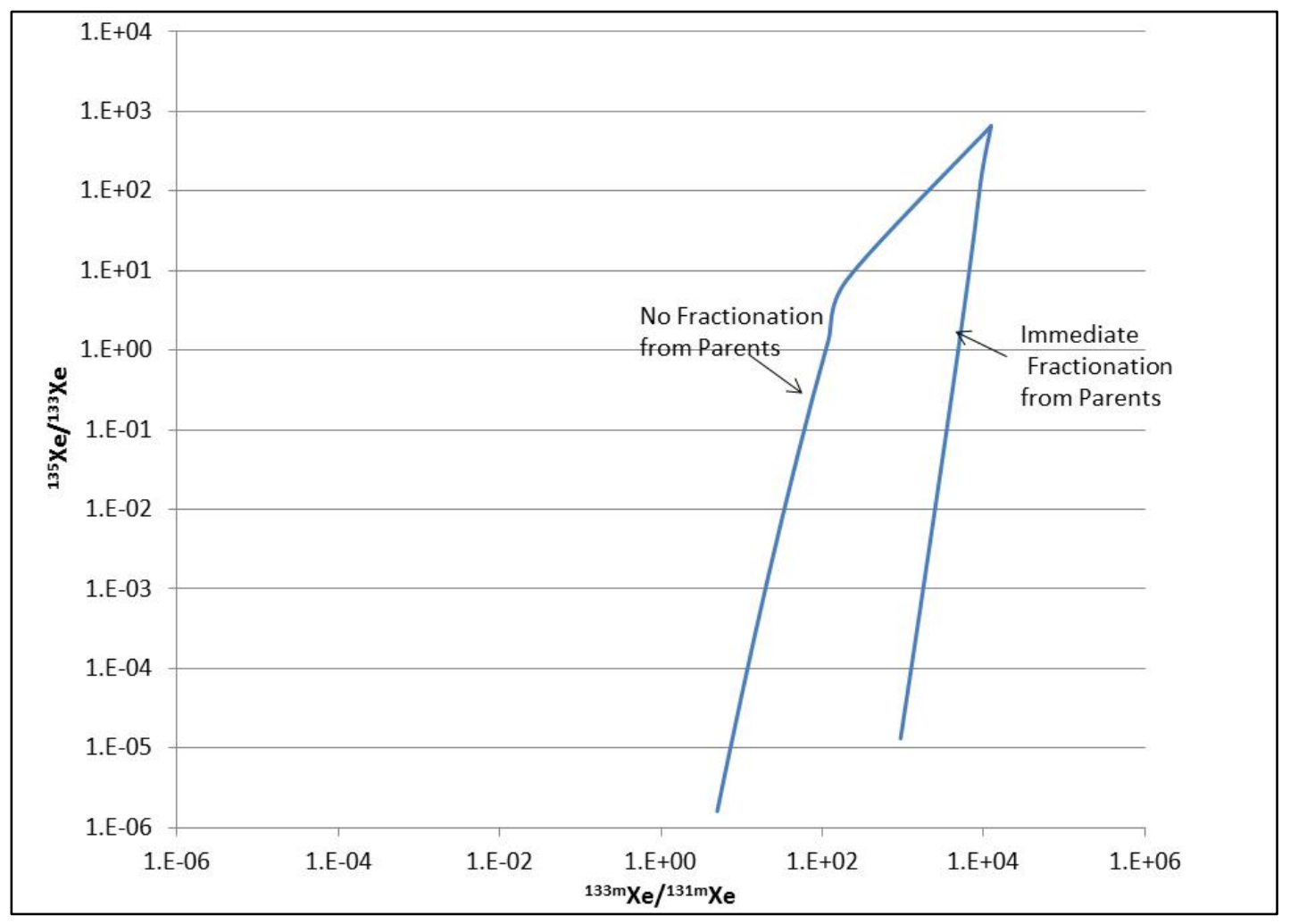

Figure 6.1. Radioxenon isotope-ratio signatures of a ${ }^{235} \mathrm{U}$ weapon detonation.

The problem with medical isotope production through uranium target irradiation is that it produces a radioxenon ratio signature similar to that of a nuclear explosion. Figure 6.2 illustrates the overlap of signals between the two types of sources. 


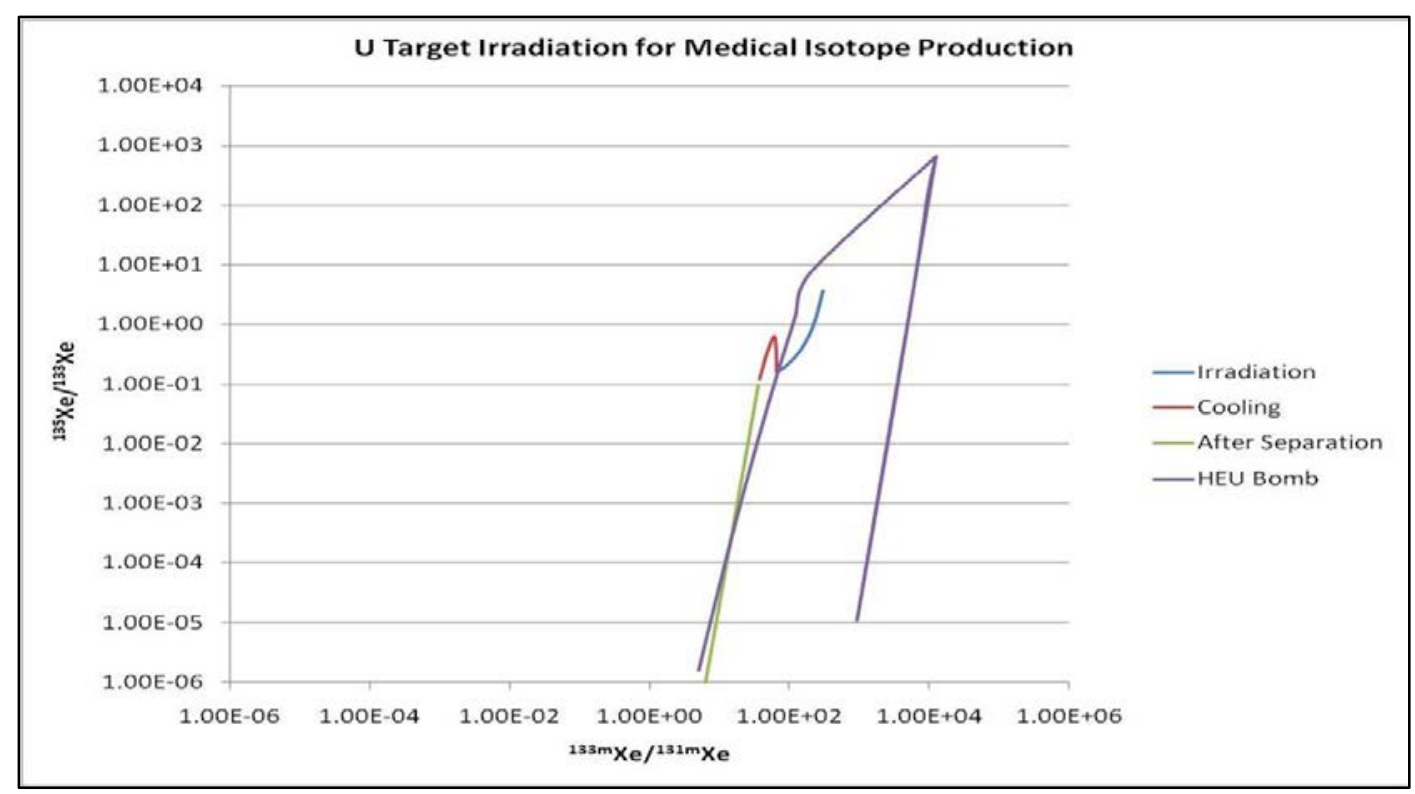

Figure 6.2. Radioxenon signatures overlap between radiopharmaceutical production and a uraniumbased nuclear-weapon explosion.

Since the radioxenon isotope signatures are dependent on the material irradiated, studies were conducted to investigate how the radioxenon signature might be changed by the introduction of additional material into the irradiation vessel. While cesium and barium activation do produce radioxenon, it was shown that the addition of these materials is not practical due to the mass that is required to produce significant quantities of radioxenon. In contrast, it was found that irradiation of $1 \mathrm{~g}$ of elemental Xe along with the $\mathrm{U}$ targets significantly shifts the radioxenon signature, as shown in Figure 6.3. Addition of this extra radioxenon notably shifts the radiopharmaceutical signature to the left. Consequently such additions could be utilized to differentiate the source signature resulting from medical isotope production from that of interest to nuclear explosion monitoring. 


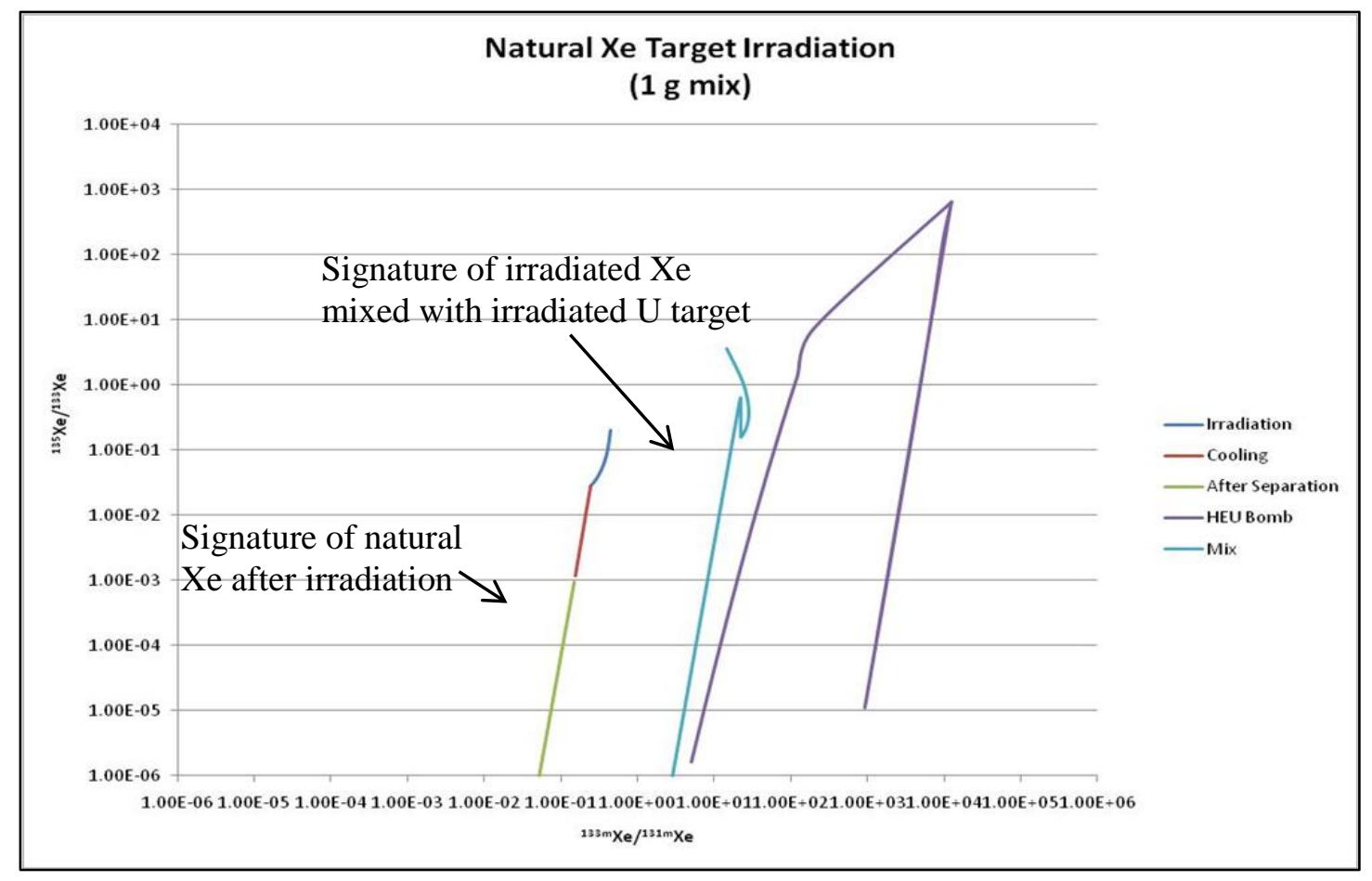

Figure 6.3. The effect on the isotope-ratio signature when natural Xe is irradiated with the U target.

Natural Xe irradiation is also produces ${ }^{125} \mathrm{Xe},{ }^{127} \mathrm{Xe}$, and ${ }^{129 \mathrm{~m}} \mathrm{Xe}$ which could also be utilized as IPF tracers. Enriched Xe isotopes could also be utilized. Isotopically enriched ${ }^{130} \mathrm{Xe}$ produces pure ${ }^{131 \mathrm{~m}} \mathrm{Xe}$ upon irradiation, which would have a similar effect to what is shown in Figure 6.3. Isotopically enriched ${ }^{124} \mathrm{Xe},{ }^{126} \mathrm{Xe}$, and ${ }^{128} \mathrm{Xe}$ could also be irradiated to produce unique radioxenon signatures. The benefit of utilizing such tracers is that that they could be monitored directly with current facilities, but they would add to radioactive effluent inventories. So while the use of tracers for identification of IPFs appears feasible, further evaluation is necessary with regard to their practical implementation.

\subsection{Xenon monitoring as a byproduct of air liquefaction}

The natural xenon (and $\mathrm{Kr}$ ) component of air provides a means of measurement of their radioactive isotopes from normal air liquefaction operations. The Khlopin Radium Institute, St. Petersburg, Russia, experimented with this approach to atmospheric xenon monitoring during the period 1979 - 1990 .

Very large xenon samples are possible, with correspondingly sensitive radioxenon measurements. Up to 4 liters of stable xenon may be stored in normal compressed air bottles. This can be trapped on $100 \mathrm{~mL}$ of 
activated charcoal which can then be analyzed by a regular well-type $\mathrm{NaI}(\mathrm{Tl})$ detector, reaching a ${ }^{133} \mathrm{Xe}$ MDC of $0.01 \mathrm{mBq} \mathrm{m}^{-3}$.

Air separation plants are widely available around the world, with major companies like Air Liquide, Linde, BOC, AP, Praxair, TNS and Airgas. Minor companies include Iwatani, Messer, Air Water, Sapio, Cryoinfra and Indura. Such facilities can be found in most countries giving a dense global network which could be useful for background studies.

There are challenges however. Gas companies might not be interested in participating; precise sampling times are difficult to estimate; contaminants could be a problem (e.g., methane); and there are hazards in hazards of handling compressed gases.

\subsection{SAUNA - equipment for low-level measurement of radioxenon}

The Swedish Automatic Unit for Noble Gas Acquisition, (SAUNA), was developed at the Swedish Research Agency (FOI) and commercialized by Gammadata. At present, 16 stations within the IMS network of CTBTO have SAUNA Systems installed for noble gas capability.

The SAUNA system performance meets or exceeds the specifications defined by the CTBT requirements for monitoring of radioactive xenon in air samples. The sampling and purification to extract the xenon is performed non-cryogenically by preparative gas chromatography. The atmospheric xenon is adsorbed on charcoal beds at ambient temperature and then further processed and purified. The stable xenon is quantified using a thermal conductivity detector, while the activity measurement of the four xenon isotopes, ${ }^{133} \mathrm{Xe},{ }^{131 \mathrm{~m}} \mathrm{Xe},{ }^{133 \mathrm{~m}} \mathrm{Xe}$, and ${ }^{135} \mathrm{Xe}$, is performed using the very sensitive beta-gamma coincidence technique allowing for high sensitivity also for the meta-stable states resulting in MDCs of $0.3,0.3,0.3$ and $0.7 \mathrm{mBq} \mathrm{m}^{-3}$ respectively. Furthermore, up-times $>95 \%$ are achievable due to good organization and tools for remote diagnosing of system problems. The SAUNA system, as deployed at IMS stations is pictured in Figure 6.4. 


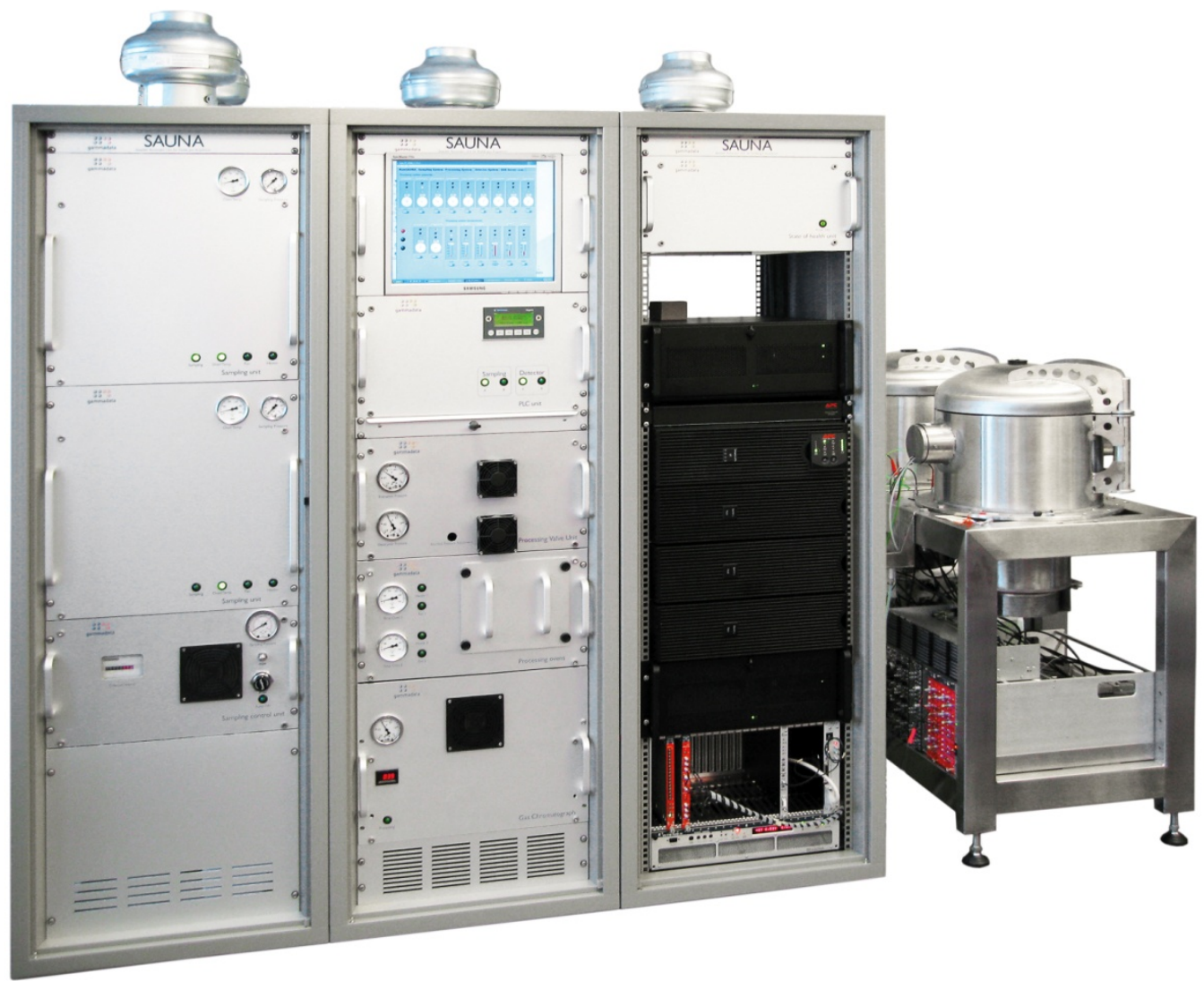

Figure 6.4. The SAUNA II system deployed at IMS noble-gas stations.

\subsection{Equipment under development for xenon measurements in Italy}

A preliminary xenon measurement system is under development at the ENEA Brasimone research centre (Bologna, Italy). The air sampling equipment consists of an absorber filled with activated charcoal and cooled with liquid nitrogen. Air is filtered to minimize the aerosol and water components (filter GF/F and silica gel respectively) before passing through the absorber. After collection, the activated charcoal is transferred to a sealed cylindrical Plexiglas container that fits inside the shield of an HPGe detector. Components of the system are shown in Figure 6.5. 

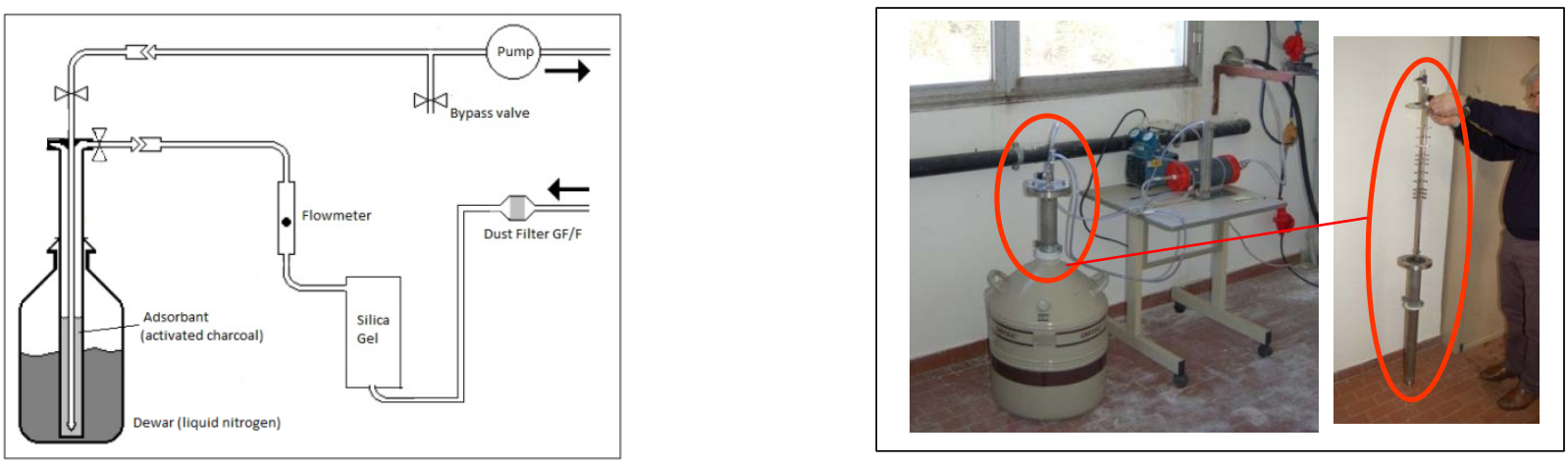

Sampling scheme (on the left) and sampling set up (on the right).
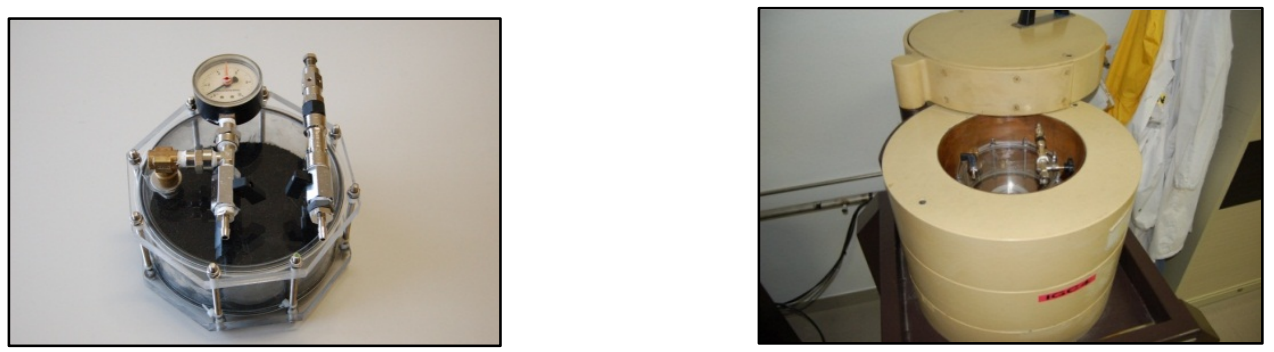

Plexiglas container containing the exposed charcoal (left) and its positioning in the shield of the germanium detector (right)

Figure 6.5. Elements of the ENEA xenon monitoring measurement system.

Initial test results for this system showed that ${ }^{133} \mathrm{Xe}$ can be detected via its $81-\mathrm{keV}$ gamma line (from 13 $\mathrm{m}^{3}$ of air). Problems were encountered with radon interference however. Further planned developments include improved drying of the air, an oven system for desorbing the trapped xenon and transfer to a Marinelli beaker before analysis, use of a higher flow rate, use of a detector with a higher counting efficiency, and possible anticoincidence shielding.

\subsection{Radioxenon standards from ${ }^{252} \mathrm{Cf}$}

The Idaho National Laboratory (INL) produces mixed ${ }^{135} \mathrm{Xe},{ }^{133 \mathrm{~m}} \mathrm{Xe},{ }^{133} \mathrm{Xe}$ and ${ }^{131 \mathrm{~m}} \mathrm{Xe}$ standards and single high-purity isotope standards for calibrating collection equipment and analytical techniques used to monitor radio xenon emissions. The mixed xenon production method is based on collection of the spontaneous fission products from a ${ }^{252} \mathrm{Cf}$ source in a stagnant volume of pressurized helium. Solids are separated from gases by sintered steel filtration. Further chromatographic purification of the fission 
gases, separates the xenon fraction for collection. ${ }^{133} \mathrm{Xe}$ and ${ }^{131 \mathrm{~m}} \mathrm{Xe}$ single isotope standards for energy calibration are purified from pharmaceutical sources via electromagnetic mass separation and chromatographic separations.

\subsection{The role of ATM in distinguishing civilian and military xenon sources}

The four methods employed to date for distinguishing between civilian and nuclear explosion radioxenon sources involve

- anomaly observations with respect to the history of concentrations found at the site;

- $\quad$ isotopic activity ratios;

- long-term frequency analyses to remove memory effects and locally induced feedback patterns;

- $\quad$ and correlation with source-receptor-sensitivities (SRS) related to known civilian sources.

Research underway at the University of Roma is attempting to optimize the role ATM in the CTBTO xenon screening process, and develop new procedures that combine ATM and the existing knowledge about the emissions from legitimate xenon sources. The Lagrangian atmospheric transport model FLEXPART will be used to determine the sensitivities between sources and receptors, drawing on data from IMS stations, with a view to optimizing the combination of the above four methods.

\subsection{Optimization of the CTBT noble-gas network}

Knowledge has improved since the IMS network was designed in 1998. Since then, calculation methodology and ATM have developed and improved, knowledge of background sources has improved, and useful monitoring equipment has been developed. It might therefore be appropriate to revisit the proposed distribution of noble-gas facilities within the IMS in order to optimize network performance. To this end, Health Canada has developed a global coverage "figure of merit" based on detections above MDC and represented as:

(sum of all detected explosions at a grid point)

(sum of all detected explosions at the best grid point)

where the denominator is the maximum number of detections at a single grid point $\left(1^{\circ} \times 1^{\circ}\right)$ in the 39station network. 
Based on this, the present network sensitivity is as depicted in Figure 6.6.

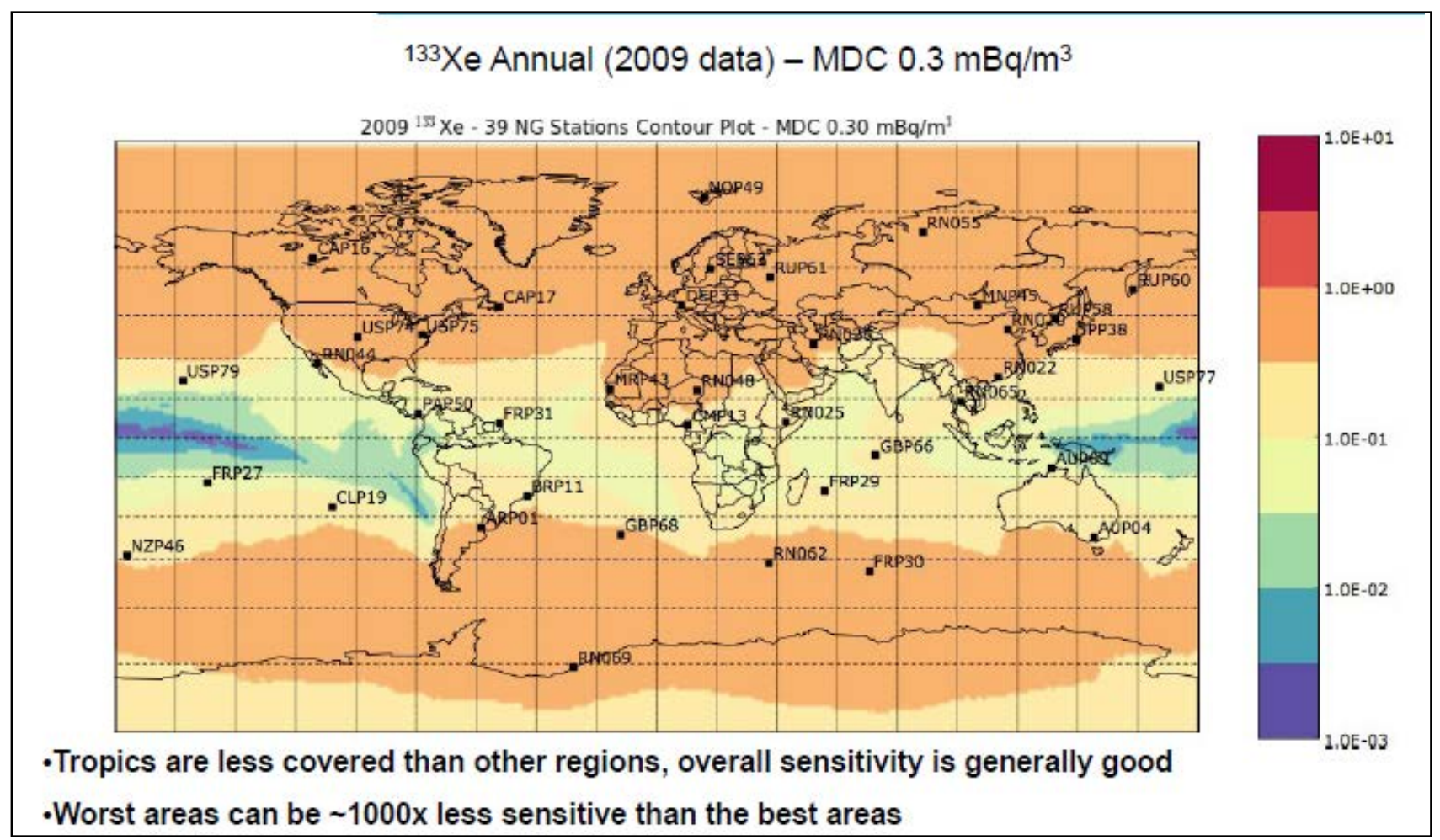

Figure 6.6. Present IMS noble-gas network performance.

Health Canada proposed that this performance could be improved by basing the network on the 40 most sensitive stations and any remaining stations (17) sensitive to background sources as shown in Figure 6.7. 


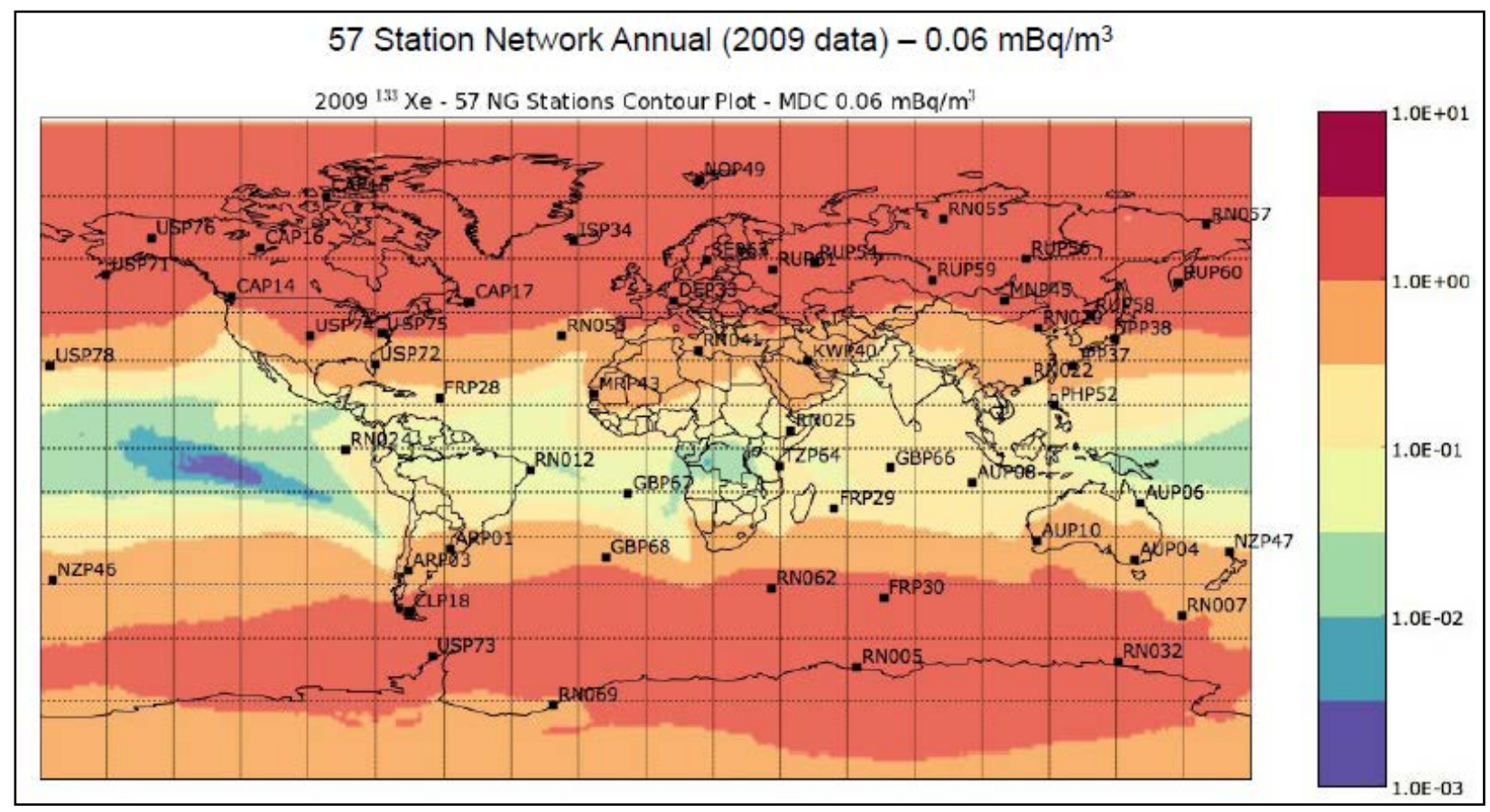

Figure 6.7. Proposed optimized 57-station IMS network.

\subsection{Fukushima: monitoring experience and lessons learned}

Fukushima experience was shared through presentations by Paul Saey (IAEA), Lars-Erik De Geer (FOI, Sweden), Aleksi Mattila (STUK, Finland), Ian Hoffmann (Health Canada), Pascal Achim (NDC, France), John Lucas (AFTAC, USA), Constantin Papastefanou (Aristotle University of Thessaloniki, Greece), Arturo Vargas (Technical University of Catalonia, Spain), Ole Ross (German NDC), Harry Miley (PNNL, USA) and Mika Nikkinen (CTBTO); supported by a posters by Giorgio Mattassi (ARPA, Italy). A selection of presentations is summarized here.

\subsection{Monitoring in Finland}

The Finnish Radiation and Nuclear Safety Authority (STUK) followed the unfolding of events at the Fukushima Daiichi nuclear power plant very closely. From the early days in the accident it was clear that considerable amounts of radioactive material were being released into atmosphere and that this release might be detectable in a global scale. The first observations from CTBTO IMS stations in and around Japan and later in North America proved to be valuable in tracking the edge of the release and also for early estimates of magnitude and composition of the atmospheric release. 
The airborne radionuclide monitoring network in Finland operated by STUK has eight high volume aerosol samplers. The samplers are equipped with both glass-fiber filters for particulate matter and TEDA activated-charcoal filters for gaseous iodine, with filters analyzed using high-resolution gamma spectrometry. The release from the damaged Fukushima Daiichi plant reached Finland around $19-21$ March, with initial particulate ${ }^{131} \mathrm{I}$ concentrations in the range of $60-120 \mu \mathrm{Bq} \mathrm{m}{ }^{-3}$. Maximum concentration values were reached about ten days later, as shown in Figure 7.1. In addition to ${ }^{131}$ I, the usual spectrum of cesium and tellurium isotopes observed at many other localities was detected also in the samples collected around Finland.

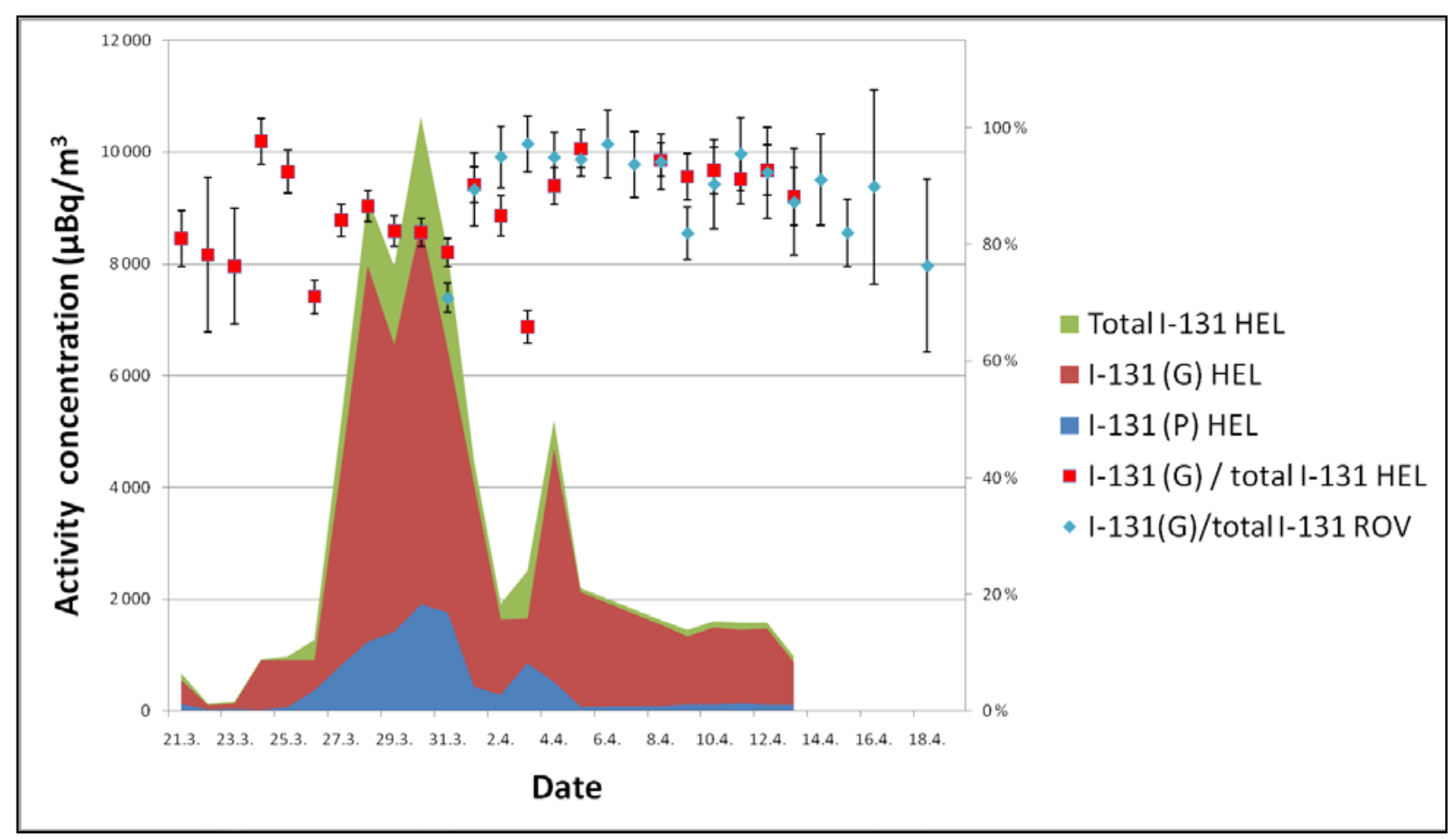

Figure 7.1. Particulate (blue), gaseous (red) and total (green) ${ }^{131}$ I concentrations in Helsinki (HEL). The gaseous fraction was between $80 \%-95 \%$ in most samples collected in Helsinki and in Rovaniemi (ROV).

The importance of sampling the gaseous iodine fraction was again highlighted by the fact that only about 5 - 20\% of the iodine was bound to particles removed by glass-fiber filter material. During the Chernobyl accident in 1986 similar gaseous and particulate fractions were measured. Although the gaseous fraction is not of primary interest from IMS point of view due to high detection limits following from the low sample size achieved with typical activated charcoal filter arrangements, for reliable dose estimates following typical NPP accident release scenarios both fractions should be sampled. 
Among various nuclide ratios studied during the accident, one investigated the removal of particulate ${ }^{131}$ I from atmosphere following radioactive decay, deposition and possible conversion to gaseous form. During the two month period for which particulate ${ }^{131}$ I was detected over Finland, the ${ }^{131} \mathrm{I} /{ }^{137} \mathrm{Cs}$ ratio was well explained by the radioactive decay of ${ }^{131}$ I alone, as demonstrated in Figure 7.2. Different deposition coefficients for particulate ${ }^{131} \mathrm{I}$ and ${ }^{137} \mathrm{Cs}$ isotopes or ${ }^{131} \mathrm{I}$ interactions with the gaseous fraction in the two month period apparently did not play a major role in the removal of particulate ${ }^{131}$ I from surface air.

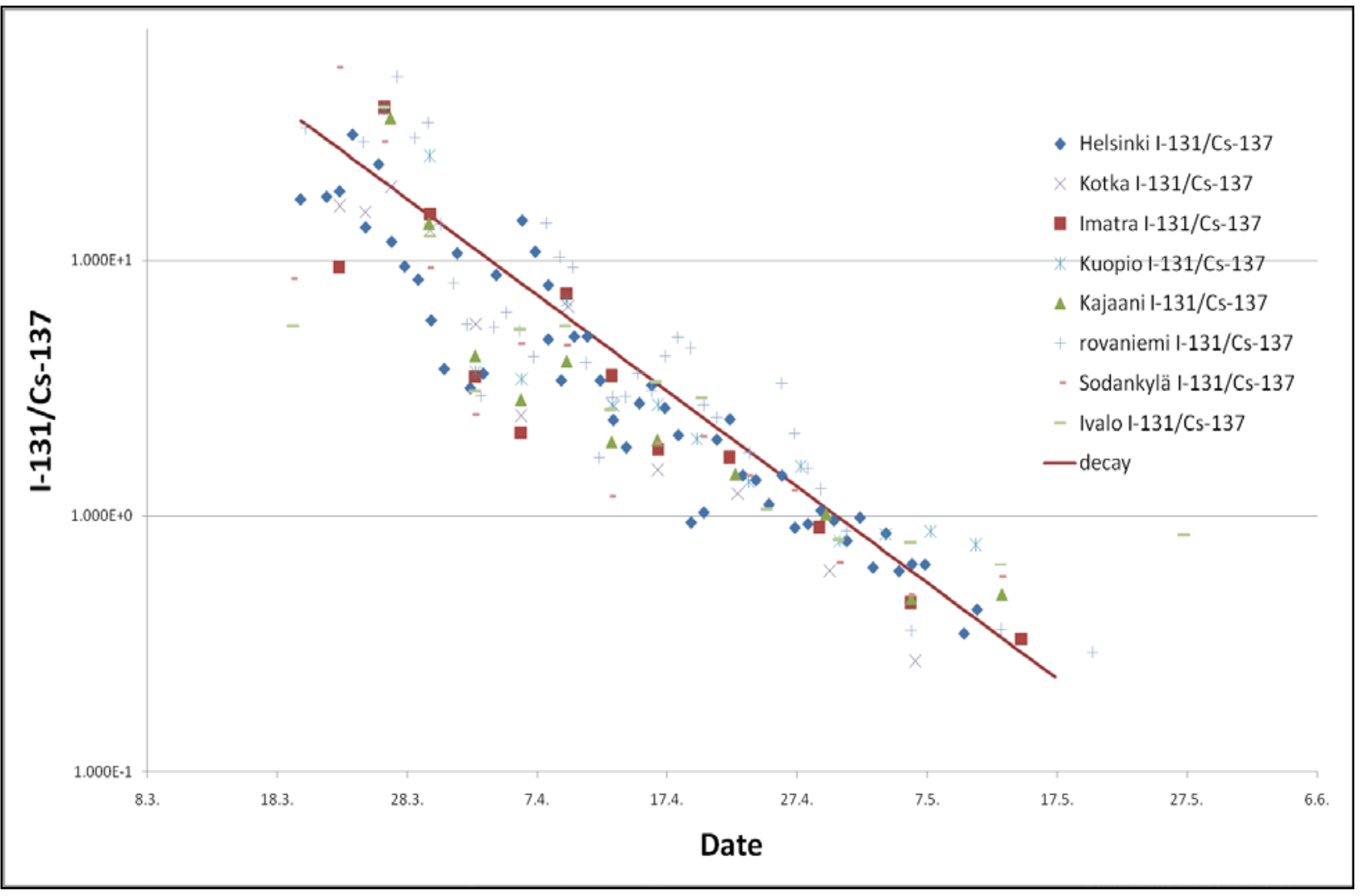

Figure 7.2. Particulate ${ }^{131} \mathrm{I} /{ }^{137} \mathrm{Cs}$ ratios at samples collected at different monitoring stations over a two month period.

\subsection{Fukushima fallout monitoring in Greece}

Fallout from the Fukushima event was monitored in Thessaloniki, Northern Greece, for about a month after it was detected there. Three different fission products - one short-lived $\left({ }^{131} \mathrm{I}\right)$, one relatively longlived $\left({ }^{134} \mathrm{Cs}\right)$ and one long-lived $\left({ }^{137} \mathrm{Cs}\right)$ - were identified in air, precipitation, soil, grass and cow/sheep milk during the period of March 24 to April 23, 2011. 
Radioecological aspects of the air-grass-cow/sheep milk-man pathway for ${ }^{131}$ I, by which the human thyroid dose is increased, were considered in terms of "eco-indices":

- the ratio, $\mathrm{A}$, of the activity concentration of ${ }^{131} \mathrm{I}$ in grass, $\mathrm{C}_{\mathrm{g}}\left(\mathrm{Bq} \mathrm{kg}^{-1}\right)$, to the activity concentration of ${ }^{131} \mathrm{I}$ in air, $\mathrm{C}_{\mathrm{a}}\left(\mathrm{Bq} \mathrm{m}^{-3}\right)$ ”

$$
\mathrm{A}=\mathrm{C}_{\mathrm{g}} / \mathrm{C}_{\mathrm{a}}, \mathrm{m}^{3} \mathrm{~kg}^{-1}
$$

- the ratio, $\mathrm{B}$, of the activity concentration of ${ }^{131} \mathrm{I}$ in cow/sheep milk, $\mathrm{C}_{\mathrm{m}}\left(\mathrm{Bq} \mathrm{L}^{-1}\right)$ to the activity concentration of ${ }^{131} \mathrm{I}$ in grass"

$$
\mathrm{B}=\mathrm{C}_{\mathrm{m}} / \mathrm{C}_{\mathrm{g}}, \mathrm{kg} \mathrm{L}^{-1} .
$$

Based on measurements of ${ }^{131} \mathrm{I}$ in air, grass and milk, the following values of A and B were obtained for the Fukushima nuclear accident:

$$
\mathrm{A}=4286 \mathrm{~m}^{3} \mathrm{~kg}^{-1} \text { and } \mathrm{B}=0.36 \mathrm{~kg} \mathrm{~L}^{-1}
$$

These compare well with values reported earlier for the Chernobyl reactor accident where $A=4233 \mathrm{~m}^{3}$ $\mathrm{kg}^{-1}$ and $\mathrm{B}=0.15 \mathrm{~kg} \mathrm{~L}^{-1}$.

\subsection{ATM lessons from Fukushima}

Atmospheric transport modeling conducted by the Federal Institute for Geosciences and Natural Resources (Germany) successfully predicted the arrival of the Fukushima plume at IMS stations using HYSPLIT and NCEP meteorological data. Further studies in the United States (PNNL) compared xenon and particulate detections. Xenon and particulate levels tracked together with time, as shown with scaled data in Figure 7.3. 


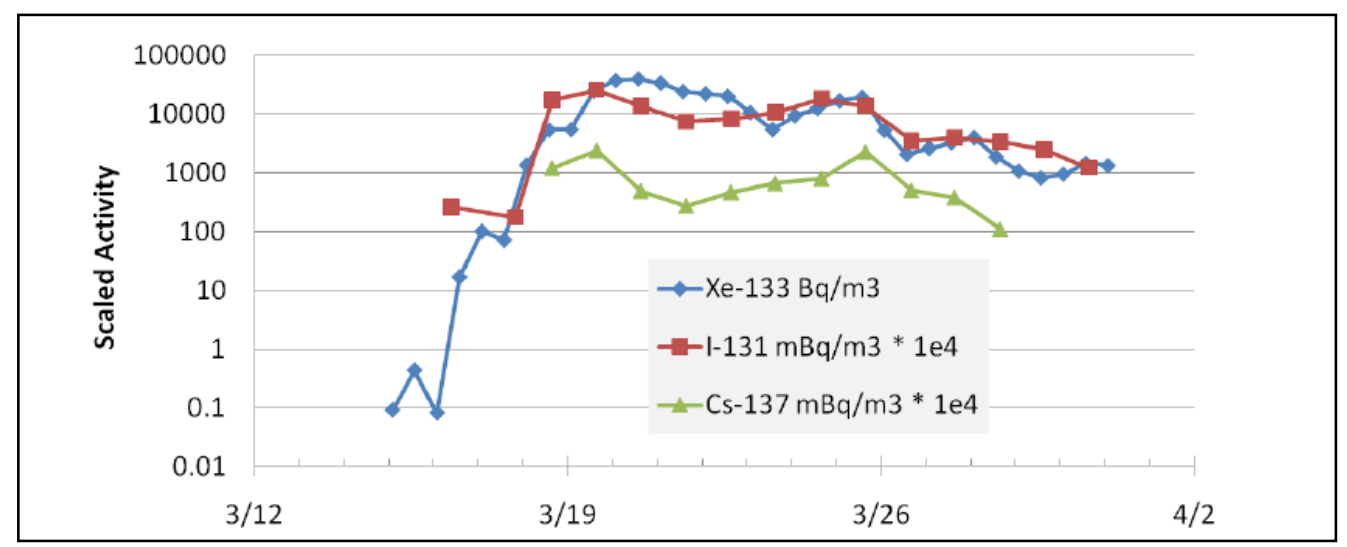

Figure 7.3. Comparison of particulate and xenon trends in detections from Fukushima.

Xenon measurements proved more sensitive in terms of early detection, with the lower analytical sensitivity being offset by the greater source term. Furthermore, aerosols suffer losses due to washout, rainout, and dry deposition while noble gases do not. The situation with iodine isotopes is not so straightforward, as both gas and particulate characteristics are involved. Further work with the iodines may demonstrate the usefulness of ${ }^{131} \mathrm{I} /{ }^{133} \mathrm{Xe}$ ratios in underground test detection.

Overall, IMS particulate and noble-gas stations performed very well in detecting and tracking the Fukushima event, with all Northern Hemisphere stations recording detections. A higher density of noblegas stations would have been useful, however, and this is a significant issue for consideration in the IMS context.

\subsection{CTBT-related Fukushima experience and lessons learned}

The CTBTO, the IMS and the International Data Centre (IDC) performed exceptionally well in the aftermath of the Fukushima event, providing valuable data through which NDCs were able to give essential advice to their National Authorities which, in turn, assisted with emergency planning.

Obviously, lessons were learned from this event which was unprecedented in CTBT-related experience. Operational lessons learned at the CTBTO IDC are summarized in Figure 7.4. 


\section{Operational}

- Emergency response within PTS - standing response procedure was applied

- More than 400 Level 5 samples, overload of work for IMS laboratories and WMO, not all requested

- Special handling of few hot samples $\left(1 \mathrm{kBq}\right.$ per $\mathrm{m}^{3}$ in air result to $20 \mathrm{MBq}$ at particulate sample)

- Need for staff to cover more challenging samples and cover weekends etc.

- Situation required daily updates

\section{Technical}

- Atmospheric modeling, tools to refine source term based on IMS detections

- Dynamic range of the measurement equipment

- Addition of dose rate/in-situ gamma measurements at IMS stations could support decision making

- Cross contamination prevention / memory effect

- Remote access to the tools

- Need for advanced tools on web. A special page was rapidly developed and served the purpose well

\section{Organizational}

- How to engage co-operation with other organizations quickly and to maintain its efficiency all along the common response process, need applicable framework for both routine and emergency periods

- What are the data that others need from PTS and PTS from others. Maintaining active mutual/multilateral information.

- If data that is available for entities that need them, advance preparation of the format is advisable

- Framework for making the information public, in what conditions the results can be made available

Figure 7.4. Lessons learned at the IDC.

On a technical level, the consistency of monitoring results across the whole IMS network is illustrated by the ${ }^{137}$ Cs vs. ${ }^{136}$ Cs plot, Figure 7.5.

The very high value of IMS and IDC outputs was clearly very much appreciated by NDCs represented at the Workshop, with particular comments as follows:

1. The reliable and high quality IMS data was deemed very valuable especially during the early days of the accident. For future accident mitigation purposes, perhaps a mechanism for a temporary relaxation of IMS monitoring data confidentiality should be devised.

2. Operational constraints on the IDC limited the timeliness of availability of review data, and a review of procedures to be followed in such situations would be helpful (this was partially overcome by the sharing of data between NDCs in some instances).

3. IDC output was very useful in enabling provision of sound advice to National Authorities and, through them, to nationals resident in or visiting Japan. 
4. Airborne analyses conducted by the USA revealed results identical to those obtained from the IMS particle samplers, demonstrating the value of systems dedicated to test monitoring to support crisis management and population protection following nuclear accidents/incidents.

5. IMS data enabled NDCs to assess the severity of damage to the Fukushima reactor cores and to calculate accurate source terms.

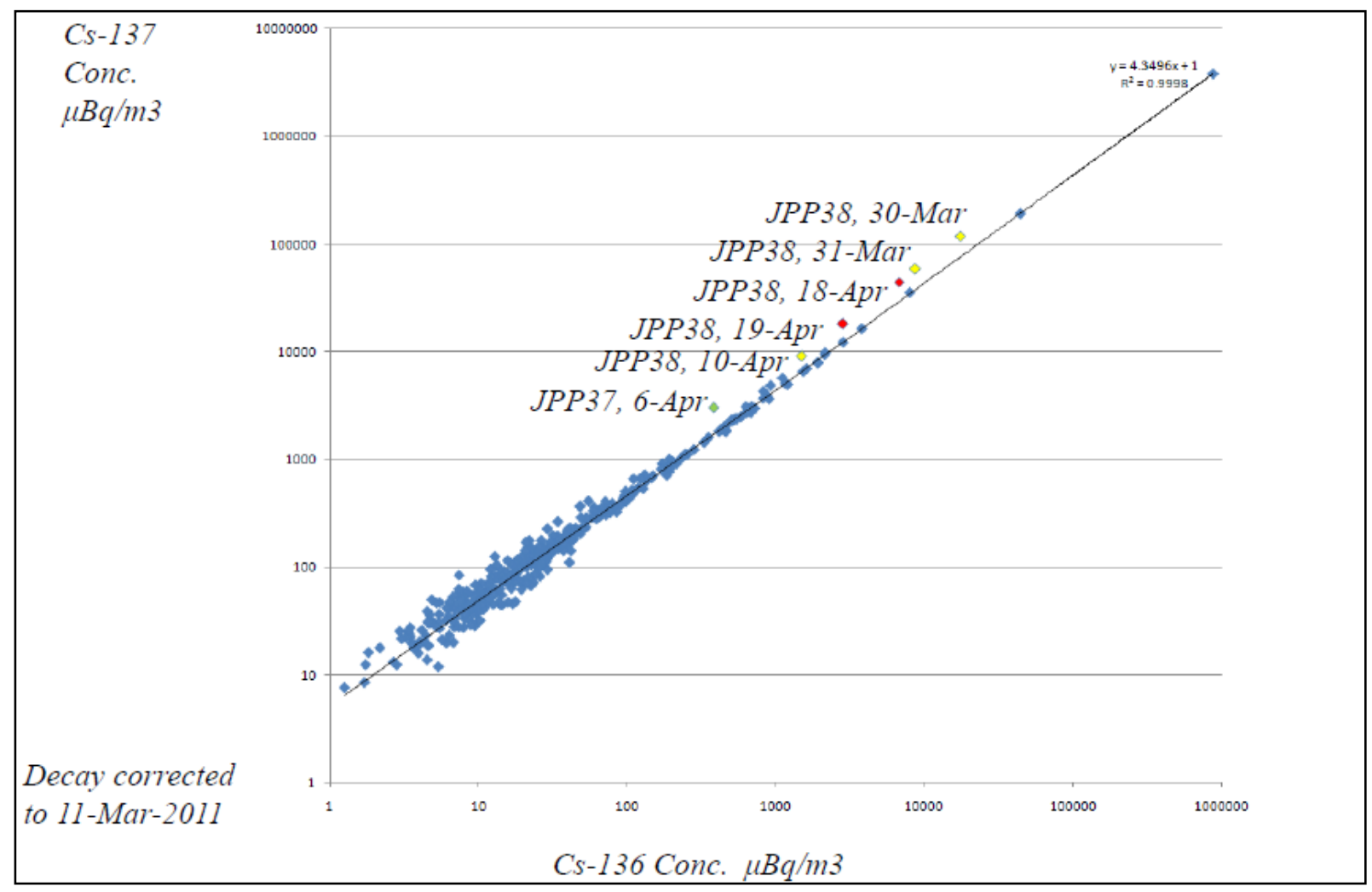

Figure 7.5. ${ }^{137} \mathrm{Cs}$ and ${ }^{136} \mathrm{Cs}$ data compared across the IMS network. 


\subsection{Observations and Conclusions}

A variety of radioisotopes are produced annually for medical and industrial purposes. The use of these isotopes has resulted in significant advances in the treatment of a number of serious ailments, to include heart disease and some forms of cancer. But while these isotopes are an obvious benefit to society, effluents released during their production can have the unintentional and undesirable effect of replicating the signatures of nuclear explosions. The production of ${ }^{99} \mathrm{Mo}$ for medical procedures is often carried out through the fissioning of uranium, followed by dissolution and capture of the isotope. Fission gases, e.g., radioactive xenon, are a by-product of this process and are not entirely contained within the production plants. The detection of these same fission gases in the environment is one of the key indicators of a nuclear explosion, and the ratios at which they are released during ${ }^{99}$ Mo production create ambiguity for current detection technologies.

WOSMIP-II was held June 13-17, 2011 to further discuss the specific challenges that isotope production presents to the monitoring community in the conduct of missions such as the Comprehensive Nuclear-Test-Ban Treaty. 63 attendees from 17 countries, as well as the International Atomic Energy Agency (IAEA) and the Comprehensive Nuclear-Test-Ban Treaty Organization (CTBTO) were represented at the most recent workshop.

WOSMIP-II attendees recognized that medical isotope production is a global problem. Models and data were presented showing that production of ${ }^{99}$ Mo in one country may significantly affect backgrounds of airborne radionuclides used in Treaty monitoring (e.g., the CTBT) across the region and, in some cases, across the globe. The background from present-day medical isotope production efforts can be managed and that it should not detract from progress towards entry-into-force of the CTBT. However, given the signaled increase in global production, steps must be taken now to manage the issue. There have already been specific instances where isotopes of interest have been detected with very little explanation and in the future these instances could be misidentified as signatures of a nuclear explosion.

Participants at WOSMIP-II discussed ways to raise visibility of the issue within the appropriate communities and to form joint experiments examining effluent monitoring, such as abatement, etc. Several parties expressed interest and enthusiasm about engaging in an experiment. Various technical solutions to mitigating the effluent problem were presented that, at first look, appear promising. One such 
solution, already implemented at the medical isotope production plant in Petten, Netherlands, currently shows very low missions and promise for further study and implementation.

It was suggested that the group work towards establishing a proposed baseline acceptable level of emissions for medical isotope production - one that was internationally accepted, but voluntary. Some of the community encouraged this approach, while others were concerned that this new standard would become the de facto regulatory standard were it proven achievable. The IAEA and CTBTO, both present at the meeting, were under-represented. It was noted that increased official engagement between the two organizations is necessary going forward that those participants at this workshop with policy backgrounds could help to promote this increased engagement. 



\section{Appendix A: WOSMIP Agenda}

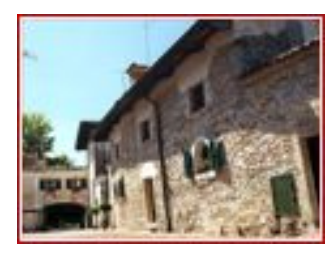

WOSMIP2011

Workshop on Signatures of Medical and Industrial Isotope Production

Pacific Northwest National Laboratory

\section{Castello di Strassoldo di Sopra • Strassoldo, Friuli-Venezia Giulia • Italy June 13-17, 2011 \\ Working Agenda}

Sunday, June 12, 2011 - Castello di Strassoldo

\begin{tabular}{|llr}
\hline $17: 00 \mathrm{~h}$ & Shuttle transfer: Grado bus station - Hotel Internazionale - Castle of Strassoldo & Gabriella di Strassoldo, Italy \\
17:00h & Start of Registration and Reception & Laura Wilhelm, USA \\
$21: 00 \mathrm{~h}$ & Shuttle transfer: Strassoldo - Hotel Internazionale - Grado bus station & \\
\hline
\end{tabular}

Manday, June 13, 2011 • Castello di Strassoldo

\begin{tabular}{|c|c|c|}
\hline 08:30h & Shuttle transfer: Grado bus station - Hotel Internazion & \\
\hline \multicolumn{3}{|c|}{ INTRODUCTORY SESSION } \\
\hline $09: 15 h$ & Welcome & $\begin{array}{r}\text { Paul Saey } \\
\text { IAEA }\end{array}$ \\
\hline 09:30h & Introductions and Overview of WOSMIP & $\begin{array}{r}\text { Ted Bowyer } \\
\text { PNNL, USA }\end{array}$ \\
\hline $09: 45 h$ & WOSMIP 2009 - Overview of the Previous Workshop & $\begin{array}{r}\text { Murray } \\
\text { Matthews } \\
\text { New Zealand }\end{array}$ \\
\hline \multicolumn{3}{|c|}{ POLICY OVERVIEW - CHAIR: TED BOWYER } \\
\hline $10: 00 \mathrm{~h}$ & KEYNOTE - Overview of Medical Isotope Production & $\begin{array}{r}\text { Ed Bradley } \\
\text { IAEA }\end{array}$ \\
\hline
\end{tabular}




\begin{tabular}{|c|c|c|}
\hline $10: 40 h$ & KEYNOTE - Why Medical Isotope Production is Relevant to the Policy Community & $\begin{array}{l}\text { Randy Bell } \\
\text { DOE/NNSA, USA }\end{array}$ \\
\hline $11: 20 h$ & Break & \\
\hline $11: 40 h$ & $\begin{array}{l}\text { KEYNOTE - Overview of the Comprehensive Nuclear-Test-Ban Treaty Verification } \\
\text { Regime }\end{array}$ & $\begin{array}{r}\text { Matthias Auer } \\
\text { CTBTO }\end{array}$ \\
\hline \multicolumn{3}{|c|}{ EMISSION AND BACKGROUND REDUCTION- CHAIR: JUDAH FRIESE } \\
\hline $12: 20 \mathrm{~h}$ & $\begin{array}{l}\text { Minimization of Fission Nuclide Release from Large-Scale Mo-99 Production } \\
\text { Facilities by Combining Processing and Off Gas Handling Technology }\end{array}$ & $\begin{array}{l}\text { A.A. Sameh } \\
\text { Germany }\end{array}$ \\
\hline $12: 45 h$ & $\begin{array}{l}\text { Impact of Medical Isotope Production on IMS Radionuclide Stations and } \\
\text { Mitigation Considerations }\end{array}$ & $\begin{array}{r}\text { Fitz Carty } \\
\text { General Dynamics, } \\
\text { USA }\end{array}$ \\
\hline $13: 10 h$ & Lunch & \\
\hline $14: 50 h$ & $\begin{array}{l}\text { Noble Gas Emissions from Mo-99 production at ANSTO and impact of } \\
\text { Subsequent Increase in Production }\end{array}$ & $\begin{array}{l}\text { Emmy Hoffmann } \\
\text { ANSTO, Australia }\end{array}$ \\
\hline $15: 15 h$ & $\begin{array}{l}\text { Overview of the Radioxenon Emissions from a Large Radiopharmaceutical Mo- } \\
99 \text { Production Facility }\end{array}$ & $\begin{array}{l}\text { Damien Braekers } \\
\text { SCK-CEN, Belgium }\end{array}$ \\
\hline $15: 40 h$ & $\begin{array}{l}\text { The Detection of I-131 and Tc-99m at RNO1 IMS Station - A Challenge to the } \\
\text { Verification Regime }\end{array}$ & $\begin{array}{l}\text { Eduardo Quintana } \\
\text { ARN, Argentina }\end{array}$ \\
\hline $16: 05 h$ & \multicolumn{2}{|l|}{ Break } \\
\hline $16: 35 h$ & \multicolumn{2}{|l|}{ Roundtable Discussion } \\
\hline $17: 35 h$ & \multicolumn{2}{|l|}{ End of Day 1 Technical Program } \\
\hline \multicolumn{3}{|c|}{ EVENING SOCIAL EVENT } \\
\hline $17: 45 \mathrm{~h}$ & \multicolumn{2}{|c|}{$\begin{array}{l}\text { Drive ( } 3 \text { min.) or Walk (10 min.) to Local Agriturismo San Gallo for a Dinner with Wine Tasting. 21:00h } \\
\text { Shuttle transfer: Agriturismo San Gallo - Hotel Internazionale - Grado bus station }\end{array}$} \\
\hline
\end{tabular}

Tuesday, June 14, 2011 • Castello di Strassoldo

\begin{tabular}{|c|c|c|}
\hline 08:30h & \multicolumn{2}{|l|}{ Shuttle transfer: Grado bus station - Hotel Internazionale - Strassoldo } \\
\hline \multicolumn{3}{|c|}{ RECENT AND PLANNED ACTIVITIES AT PRODUCTION FACILITIES - CHAIR: A.A. SAMEH } \\
\hline 09:15h & Current Experience and Operations at ANSTO & $\begin{array}{r}\text { Michael Druce } \\
\text { ANSTO, Australia }\end{array}$ \\
\hline 09:40h & Medical Isotope Production in Iran: Past and Present & $\begin{array}{r}\text { Mohammad Sabzian } \\
\text { Shahid Beheshti University, Iran }\end{array}$ \\
\hline $10: 05 h$ & Mo-99 Production from LEU Foil Target & $\begin{array}{r}\text { Budi Briyatmoko } \\
\text { National Atomic Energy Agency, } \\
\text { Indonesia }\end{array}$ \\
\hline $10: 30 h$ & $\begin{array}{l}\text { New Method to Produce High Specific Activity Medical Isotopes Using } \\
\text { Alternate Neutron Sources }\end{array}$ & $\begin{array}{r}\text { Greg Piefer } \\
\text { SHINE Med. Technologies, USA }\end{array}$ \\
\hline $10: 55 h$ & Break & \\
\hline \multicolumn{3}{|c|}{ EXPERIENCE IN MONITORING MEDICAL ISOTOPE PRODUCTION FACILITIES - CHAIR: PAUL SAEY } \\
\hline $11: 25 \mathrm{~h}$ & $\begin{array}{l}\text { Characterisation of Noble Gas Releases at ANSTO's Mo-99 facility via } \\
\text { Nal and HPGe gamma spectrometry }\end{array}$ & $\begin{array}{l}\text { Emmy Hoffmann } \\
\text { ANSTO, Australia }\end{array}$ \\
\hline
\end{tabular}




\begin{tabular}{|c|c|c|}
\hline $11: 50 h$ & Issues and Experience in Emission Quantification at Nordion Inc. & $\begin{array}{r}\text { Richard DeCaire } \\
\text { Nordion Inc., Canada }\end{array}$ \\
\hline $12: 15 h$ & High Resolution Monitoring System for IRE Stack Releases & $\begin{array}{l}\text { Benoit Deconninck } \\
\text { IRE-Elit, Belgium }\end{array}$ \\
\hline $12: 40 \mathrm{~h}$ & Lunch & \\
\hline $14: 10 h$ & Spectrometry Systems Used as Stack Monitors & $\begin{array}{r}\text { Michel Rotty } \\
\text { Canberra }\end{array}$ \\
\hline $14: 35 h$ & $\begin{array}{l}\text { Use of Xenon Emission Data to Calculate the Effect of Pharmaceutical } \\
\text { Facilities on CTBT Xenon Detections }\end{array}$ & $\begin{array}{r}\text { Mika Nikkinen } \\
\text { CTBTO }\end{array}$ \\
\hline $15: 00 \mathrm{~h}$ & Medical Isotopes Studies & $\begin{array}{r}\text { Judah Friese } \\
\text { PNNL, USA }\end{array}$ \\
\hline $15: 30 h$ & Break & \\
\hline $16: 00 h$ & Roundtable Discussion & \\
\hline $17: 00 \mathrm{~h}$ & End of Day 2 Technical Program & \\
\hline \multicolumn{3}{|c|}{ EVENING SOCIAL EVENT } \\
\hline $17: 30 h$ & \multicolumn{2}{|c|}{$\begin{array}{l}\text { Direct drive with a bus from Strassoldo to the historical winery "Perusini" - visit and wine tasting, followed by a } \\
\text { dinner in the Osteria "Al Postiglione", sponsored by GammaData Sweden. Note: for those who do not wish to } \\
\text { attend, there will be the usual shuttle transfer (at 17.30h): Strassoldo - Hotel Internazionale - Grado bus stop }\end{array}$} \\
\hline
\end{tabular}

\section{Wednesday, June 15, 2011 • Castello di Strassoldo}

\begin{tabular}{|c|c|c|}
\hline 08:30h & \multicolumn{2}{|l|}{ Shuttle transfer: Grado bus station - Hotel Internazionale - Strassoldo } \\
\hline \multicolumn{3}{|c|}{ MONITORING SCIENCE AND TECHNOLOGY - CHAIR: MATTHIAS AUER } \\
\hline $09: 15 h$ & $\begin{array}{l}\text { Security Monitoring and Identification of Medical Radionuclides: } \\
\text { Interruptions and False Alarms }\end{array}$ & $\begin{array}{r}\text { Kurt Ungar } \\
\text { Health Canada }\end{array}$ \\
\hline 09:40h & Tracers for Radiopharmaceutical Production Facilities & $\begin{array}{r}\text { Steven Biegalski } \\
\text { University of Texas/PNNL, USA }\end{array}$ \\
\hline $10: 05 h$ & $\begin{array}{l}\text { Changes in Xe-133 and Xe-135 Ratio during Mo-99 and I-131 } \\
\text { Separation Processes }\end{array}$ & $\begin{array}{l}\text { Eduardo Carranza } \\
\text { CNEA, Argentina }\end{array}$ \\
\hline $10: 30 h$ & Contributions of Reactors to the Natural Background & $\begin{array}{l}\text { Mohammed Javad Safari } \\
\text { Sharif University of Tech., Iran }\end{array}$ \\
\hline $10: 55 h$ & Break & \\
\hline $11: 25 h$ & Reach-back Support for the 2010 Vancouver Olympic Games & $\begin{array}{r}\text { Kurt Ungar } \\
\text { Health Canada }\end{array}$ \\
\hline 11:50h & $\begin{array}{l}\text { Analysis of Krypton-Xenon Mixture Obtained as a Byproduct of Air } \\
\text { Liquefaction for Radioxenon Content }\end{array}$ & $\begin{array}{r}\text { Kirill Khrustalev } \\
\text { CTBTO }\end{array}$ \\
\hline $12: 15 h$ & CTBT Noble Gas Detection Network Density & $\begin{array}{l}\text { Ian Hoffman } \\
\text { Health Canada }\end{array}$ \\
\hline $12: 40 h$ & Lunch & \\
\hline $14: 10 \mathrm{~h}$ & $\begin{array}{l}\text { Can We Estimate Unknown Sources of Atmospheric Radioactivity } \\
\text { by Inverse Modeling? }\end{array}$ & $\begin{array}{r}\text { Petra Seibert } \\
\text { University of Natural Resources and } \\
\text { Applied Life Sciences }(B O K U) \text {, Austria }\end{array}$ \\
\hline $14: 35 h$ & $\begin{array}{l}\text { Atmospheric Transport Modeling for Releases from Fukushima and its } \\
\text { Evaluation with Radionuclide Detections of the International Monitoring } \\
\text { System }\end{array}$ & $\begin{array}{r}\text { Ole Ross } \\
\text { Federal Institute for Geosciences and } \\
\text { Natural Resources, German NDC }\end{array}$ \\
\hline
\end{tabular}




$\begin{array}{ll}15: 00 \mathrm{~h} & \begin{array}{l}\text { Atmospheric transport modeling on Fukushima and the implication on } \\ \text { next gen IMS systems }\end{array} \\ 15: 25 \mathrm{~h} & \text { Break } \\ 15: 55 \mathrm{~h} & \text { Roundtable Discussion } \\ 16: 55 \mathrm{~h} \quad \text { End of Day } 3 \text { Technical Program } & \begin{array}{r}\text { Harry Miley } \\ P N N L, \text { USA }\end{array} \\ 17: 15 \mathrm{~h} \quad \text { Shuttle transfer: Strassoldo - Hotel Internazionale - Grado bus stop }\end{array}$

Shursday, June 16, 2011 • Castello di Strassoldo

\begin{tabular}{|c|c|c|}
\hline 08:30h & Shuttle transfer: Grado bus station - Hotel Internazionale - Strassoldo & \\
\hline \multicolumn{3}{|c|}{ POSTER SESSION } \\
\hline $9: 15 \mathrm{~h}$ & Poster Session & \\
\hline & SAUNA Equipment for Low-Level Measurement of Radioactive Xenon & $\begin{array}{r}\text { Helena Burglund } \\
\text { Gammadata SAUNA Systems, } \\
\text { Sweden }\end{array}$ \\
\hline & PNNL Monitoring of Fukushima Reactor Incident & $\begin{array}{l}\text { Harry Miley } \\
\text { PNNL, USA }\end{array}$ \\
\hline & $\begin{array}{l}\text { Production of Radio Xenon Standards for Calibration at the Idaho National } \\
\text { Laboratory }\end{array}$ & $\begin{array}{r}\text { Robert K. Hague } \\
\text { INL, USA }\end{array}$ \\
\hline & Preliminary activities on the measurement of noble gases at ENEA & $\begin{array}{l}\text { Elisabetta Nava } \\
\text { ENEA, Italy }\end{array}$ \\
\hline & Characterization of Radioxenon Atmospheric Discharges in Belgium & $\begin{array}{l}\text { Johan Camps } \\
\text { SCK-CEN, Belgium }\end{array}$ \\
\hline & $\begin{array}{l}\text { Measurement of isotopes at long distances from Fukushima: the case of Friuli } \\
\text { Venezia Giulia region (NE Italy) }\end{array}$ & $\begin{array}{l}\text { Giorgio Mattassi } \\
\text { ARPA FVG, Italy }\end{array}$ \\
\hline & $\begin{array}{l}\text { Improving Detection Capability by Combining ATM and Knowledge of Radioxenon } \\
\text { Sources }\end{array}$ & $\begin{array}{l}\text { Michael Schöppner } \\
\text { University of Roma, Italy }\end{array}$ \\
\hline \multicolumn{3}{|c|}{ AWARDS PRESENTATION } \\
\hline $11: 15 h$ & Awards Presentation & \\
\hline $11: 45 h$ & End of Day 4 Technical Program / Lunch & \\
\hline
\end{tabular}

\section{SOCIAL EVENT-TOUR OF VENICE}

13:00h Travel to Venice by Bus; Boat and Guided Walking Tour Around the Centre (San Marco), Visit the Private Palace Albrizzi, and Workshop Dinner in the Palazzo Flangini at the Canal Grande.

21:30h Shuttle transfer: Venice - Strassoldo - Hotel Internazionale - Grado bus station 
Friday, June 17, 2011 • Castello di Strassoldo

\begin{tabular}{|c|c|c|}
\hline 08:30h & \multicolumn{2}{|l|}{ Shuttle transfer: Grado bus station - Hotel Internazionale - Strassoldo } \\
\hline & \multicolumn{2}{|c|}{ FUKUSHIMA: MONITORING EXPERIENCE AND LESSONS LEARNED - CHAIR: HARRY MILEY } \\
\hline 09:15h & $\begin{array}{l}\text { The } 2011 \text { Earthquake off the Pacific Coast of Tohoku and the Fukushima } \\
\text { Daiichi NPP Accident }\end{array}$ & $\begin{array}{r}\text { Paul Saey } \\
\text { IAEA }\end{array}$ \\
\hline 09:35h & $\begin{array}{l}\text { The First Days of the Fukushima Accident Seen from the Swedish } \\
\text { Horizon }\end{array}$ & $\begin{array}{l}\text { Lars-Erik De Geer } \\
\text { FOI, Sweden }\end{array}$ \\
\hline 09:55h & $\begin{array}{l}\text { Airborne Radionuclide Concentrations in Finland Following the } \\
\text { Fukushima Daiichi Nuclear Power Plant Accident }\end{array}$ & $\begin{array}{r}\text { Aleksi Mattila } \\
\text { STUK-Radiation and Nuclear Safety } \\
\text { Authority, Finland }\end{array}$ \\
\hline $10: 15 \mathrm{~h}$ & $\begin{array}{l}\text { Fukushima Case Study: How National Technical Means and Other } \\
\text { Cooperating Facilities can Supplement the Information Gained by the } \\
\text { IMS/IDC }\end{array}$ & $\begin{array}{r}\text { lan Hoffman } \\
\text { Health Canada }\end{array}$ \\
\hline $10: 35 h$ & French Monitoring Experience after Fukushima Reactor Incident & $\begin{array}{l}\text { Pascal Achim } \\
\text { French NDC }\end{array}$ \\
\hline $10: 55 h$ & Break & \\
\hline $11: 20 \mathrm{~h}$ & Particle Collections of the Fukushima Reactor Accident via Aircraft & $\begin{array}{l}\text { John Lucas } \\
\text { AFTAC, USA }\end{array}$ \\
\hline $11: 40 \mathrm{~h}$ & $\begin{array}{l}\text { The Fukushima Nuclear Accident and its Influence to Thessaloniki, } \\
\text { Northern Greece }\end{array}$ & $\begin{array}{r}\text { Constantin Papastefanou } \\
\text { Aristotle University of Thessaloniki, } \\
\text { Greece }\end{array}$ \\
\hline $12: 00 h$ & $\begin{array}{l}\text { Atmospheric Radioisotopes Measured in Barcelona After the Fukushima } \\
\text { Accident }\end{array}$ & $\begin{array}{r}\text { Arturo Vargas } \\
\text { Institute of Energy Technologies, } \\
\text { Technical University of Catalonia, } \\
\text { Spain }\end{array}$ \\
\hline $12: 20 \mathrm{~h}$ & $\begin{array}{l}\text { Operational Experience of CTBTO Related to the Fukushima Nuclear } \\
\text { Accident }\end{array}$ & $\begin{array}{r}\text { Mika Nikkinen } \\
\text { CTBTO }\end{array}$ \\
\hline $12: 45 h$ & Lunch & \\
\hline $14: 15 \mathrm{~h}$ & Roundtable: Fukushima Lessons Learned & \\
\hline \multicolumn{3}{|c|}{ SUMMARY OF WORKSHOP } \\
\hline 15:00h & Roundtable: Next Steps for WOSMIP & \\
\hline 16:00h & End of WOSMIP 2011 & \\
\hline $16: 15 \mathrm{~h}$ & Shuttle transfer: Strassoldo - Hotel Internazionale - Grado bus stop & \\
\hline
\end{tabular}





\section{Distribution}

\section{Foreign Distribution}

1. Achim, Pascal

pascal.achim@cea.fr

FRANCE

2. Auer, Matthias

matthias.auer@ctbto.org

AUSTRIA

3. Barbosa, Luis

luis.barbosa@covidien.com

HOLLAND

4. Bayat, Mahdi

sawyer.taylor@hotmail.com

IRAN

5. Berglund, Helena

Helena.berglund@gammadata.se

SWEDEN

6. Bradley, Ed

e.bradley@iaea.org

AUSTRIA

7. Braekers, Damien

damien.braekers@sckcen.be

BELGIUM

8. Bryatmoki, Budi

budibri@batan.go.id

INDONESIA

9. Carranza, Eduardo

edcarran@cae.cnea.gov.ar

ARGENTINA

10. Decaire, Richard

richard.decaire@nordion.com

CANADA

11. Deconninck, Benoit

benoit.deconninck@are.eu

BELGIUM

12. De Geer, Lars-Eric

ledg@foi.se

SWEDEN
13. Dittrich, Sven

sven.dittrich@gsg-int.com

SWITZERLAND

14. Druce, Michael

mjd@ansto.gov.au

AUSTRALIA

15. Garavagla, Massimo

c/o Concettina Giovani

ITALY

16. Giovani, Concettina

concettina.giovani@arpa.fvg.it

ITALY

17. Hoffman, Ian

ian.hoffman@hc-sc.gc.ca

CANADA

18. Hoffmann, Emmy

emh@ansto.gov.au

AUSTRALIA

19. Khrustalev, Kirill

kirill.khrustalev@ctbto.org

AUSTRIA

20. Le Petit, Gilbert gilbert.le-petit@cea.fr

FRANCE

21. Matthews, Murray murray.matthews@xtra.co.nz

NEW ZEALAND

22. Mattila, Aleski

aleski.mattila@stuk.fi

FINLAND

23. Nadalut, Barbara

barbara.nadalut@ctbto.org

AUSTRIA

24. Nava, Elisabetta

elisabetta.nava@enea.it

ITALY 
25. Nikkinen mika.nikkinen@ctbto.org AUSTRIA

26. Padoani, Franca franca.padoani@enea.it ITALY

27. Papastefanou, Constantin papastefanou@physics.auth.gr GREECE

28. Quintana, Eduardo equintana@arn.gov.ar ARGENTINA

29. Ringbom, Anders anders.ringbom@foi.se SWEDEN

30. Ross, Ole ole.ross@bgr.de GERMANY

31. Rossi, Massimo c/o Concettina Giovani ITALY

32. Rotty, Michel michel.rotty@canberra.com BELGIUM

33. Saey, Paul p.saey@iaea.org AUSTRIA

34. Sabzian, Mohammad sawyer.taylor@hotmail.com IRAN

35. Sameh, A.A. a.a.sameh@gmx.de GERMANY

36. Schoppner, Michael schoppner@live.com ITALY
37. Siebert, Petra petra.seibert@boku.ac.at AUSTRIA

38. Vargas, Arturo arturo.vargas@upc.edu SPAIN

39. Ungar, Kurt kurt.ungar@hc-sc.gc.ca CANADA

40. Zoghalchali, Mohammad Reza Zare sawyer.taylor@hotmail.com IRAN

\section{Local Distribution}

1. Bell, Randy randy.bell@nnsa.doe.gov

2. Biegalski, Steven biegalski@mail.utexas.edu

3. Bobiak, Stephanie bobiakSM@state.gov

4. Bowyer, Ted ted.bowyer@pnnl.gov

5. Cameron, Ian ian.cameron@pnnl.gov

6. Carty, Fitz fitz.carty@gd.ais.com

7. Douglas, Matthew matthew.douglas@pnnl.gov

8. Evans, Tim timothy.evans@nnsa.doe.gov

9. Hague, Robert K. robert.hague@inl.gov 
10. Ingraham, Joanna joanna.ingraham@dtra.mi

11. Kreek, Steven kreek1@llnl.gov

12. Lucas, John

C.john.lucas@patrick.af.mil

13. Miley, Harry harry.miley@ppnnl.gov

14. Nall, Buphus buphus.nall@smdc.army.mil

15. Newman, Mike mike.newman@nnsa.doe.gov

16. Payne, Rosara rosara.payne@pnnlgov

17. Pickens, Mark mark.pickens@us.army.mil

18. Piefer, Gregory greg.p@shinemed.com

19. Simpson, Jean jean.simpson@pnnl.gov

20. Wilhelm, Laura laura.wilhelm@pnnl.gov 




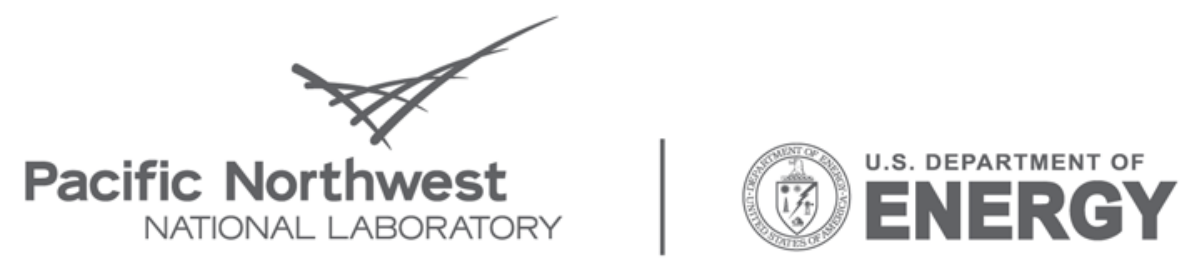

Proudly Operated by Battelle Since 1965

902 Battelle Boulevard

P.O. Box 999

Richland, WA 99352

1-888-375-PNNL (7665)

www.pnl.gov 